\title{
\#USES
}

\section{Mountains, Glaciers, and Mines The Geological Story of the Blue River Valley, Colorado, and Its Surrounding Mountains}

Circular 1400

U.S. Department of the linterior U.S. Feological survey

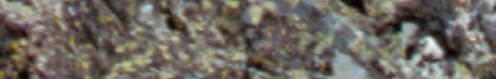
Lestions a 

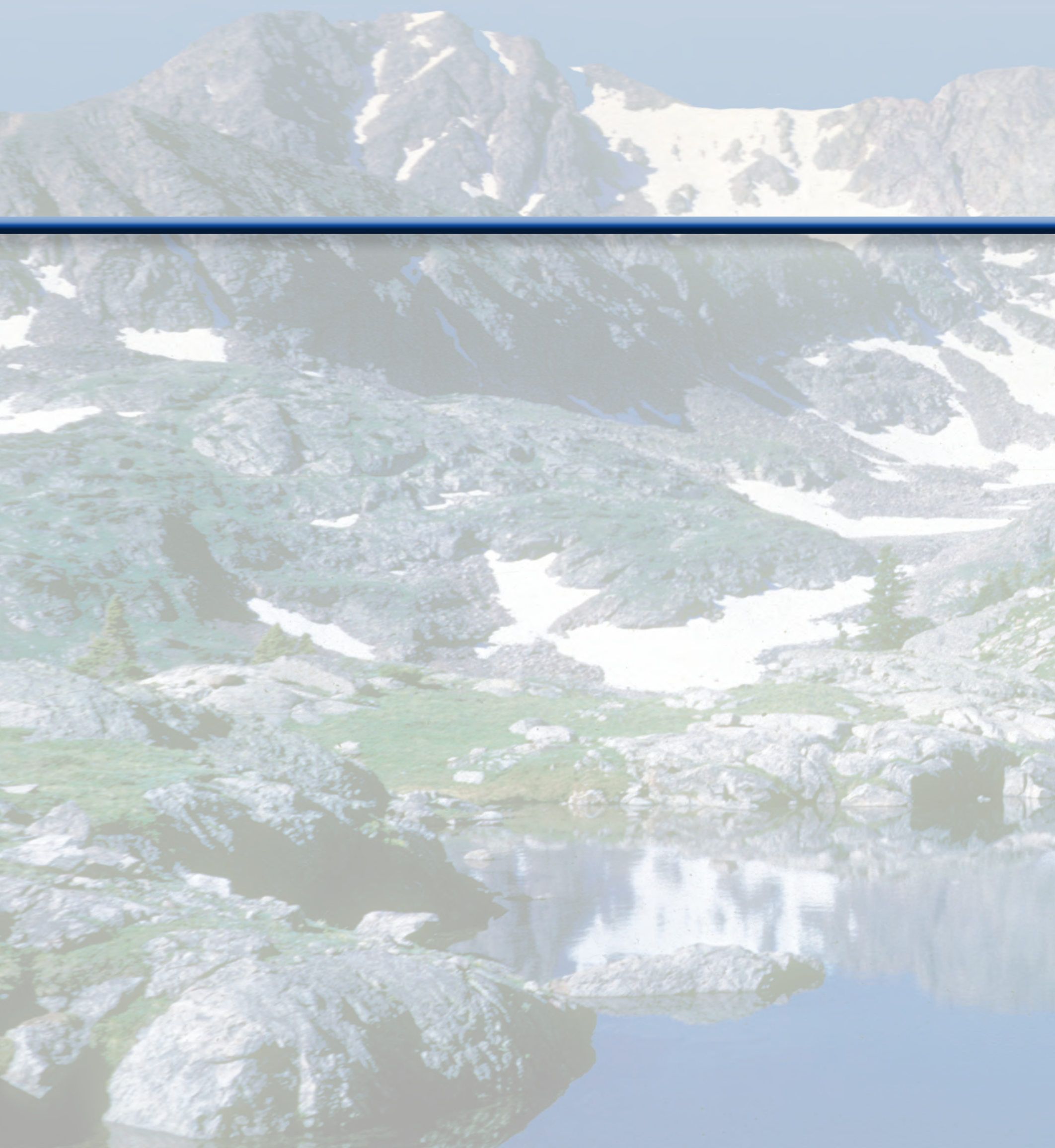


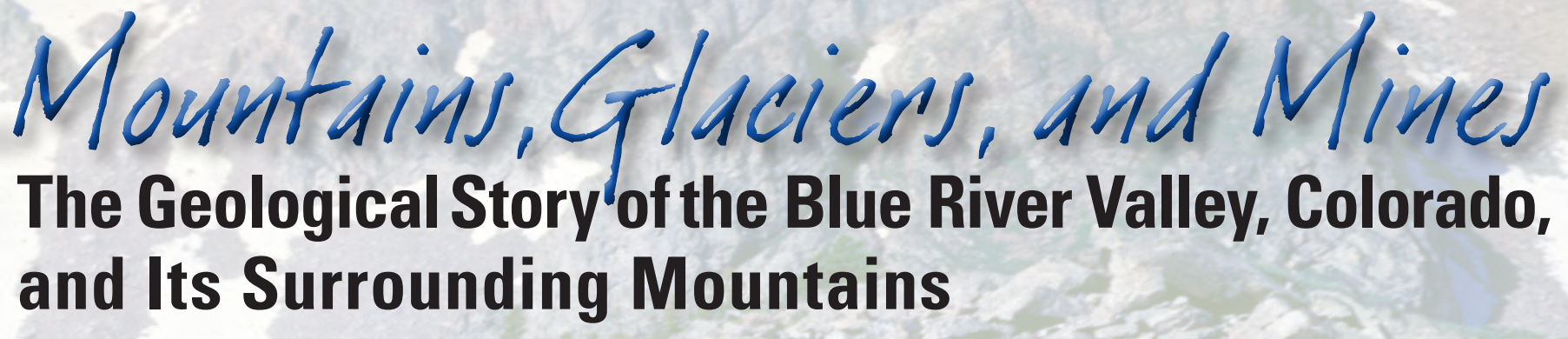

By Karl S. Kellogg, Bruce Bryant, and Ralph R. Shroba

Circular 1400 


\section{U.S. Department of the Interior SALLY JEWELL, Secretary}

\section{U.S. Geological Survey Suzette M. Kimball, Director}

\section{U.S. Geological Survey, Reston, Virginia: 2016}

For more information on the USGS - the Federal source for science about the Earth, its natural and living resources, natural hazards, and the environment-visit http://www.usgs.gov or call 1-888-ASK-USGS.

For an overview of USGS information products, including maps, imagery, and publications,

visit http://www.usgs.gov/pubprod.

To order this and other USGS information products, visit http://store.usgs.gov.

Any use of trade, product, or firm names is for descriptive purposes only and does not imply endorsement by the U.S. Government.

Although this report is in the public domain, permission must be secured from the individual copyright owners to reproduce any copyrighted material contained within this report.

Suggested citation:

Kellogg, K.S., Bryant, Bruce, and Shroba, R.R., 2016, Mountains, glaciers, and mines-The geological story of the Blue River valley, Colorado, and its surrounding mountains: U.S. Geological Survey Circular 1400, 46 p., http://dx.doi.org/10.3133/cir1400.

\section{Library of Congress Cataloging-in-Publication Data}

Kellogg, Karl S.

Mountains, glaciers, and mines : the geological story of the Blue River Valley, colorado, and its surrounding mountains / by Karl S. Kellogg, Bruce Bryant, and Ralph R. Shroba.

pages cm. -- (Circular ; 1400)

Includes bibliographical references.

ISBN 978-1-4113-3966-8 (pbk.)

1. Geology--Colorado--Blue River Valley. 2. Mountains--Colorado. I. Bryant, Bruce, 1930- II. Shroba, R. R. III. Title. OE92.B58K45 2016

$557.88^{\prime} 65--d c 23$

2015034498

ISSN 1067-084X (print)

ISSN 2330-5703 (online)

ISBN 978-1-4113-3966-8 


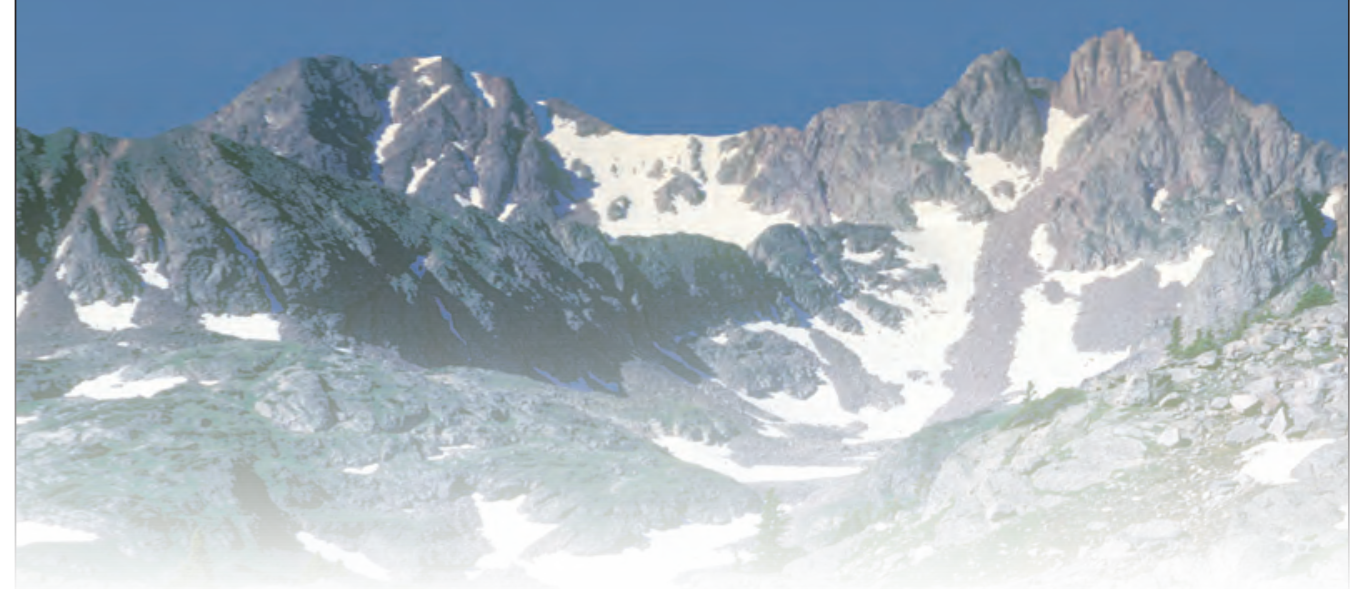

Overview of This Report

This report describes, in a nontechnical style, the geologic history and mining activity in the Blue River region of Colorado, which includes all of Summit County. The geologic story begins with the formation of ancient basement rocks, as old as about 1700 million years, and continues with the deposition of sedimentary rocks on a vast erosional surface beginning in the Cambrian Period (about 530 million years ago). This deposition was interrupted by uplift of the Ancestral Rocky Mountains during the late Paleozoic Era (about 300 million years ago). The present Rocky Mountains began to rise at the close of the Mesozoic Era (about 65 million years ago). A few tens of millions years ago, rifting began to form the Blue River valley; a major fault along the east side of the Gore Range dropped the east side down, forming the present valley. The valley once was filled by sediments and volcanic rocks that are now largely eroded. During the last few hundred-thousand years, at least two periods of glaciation sculpted the mountains bordering the valley and glaciers extended down the Blue River valley as far south as present Dillon Reservoir. Discovery of deposits of gold, silver, copper, and zinc in the late 1800s, particularly in the Breckenridge region, brought an influx of early settlers. The world-class molybdenum deposit at Climax, mined since the First World War, reopened in 2012 after a period of closure.

The report includes a glossary to explain geologic terms used in the text, and numerous photos, maps, and diagrams illustrate the geologic principles discussed. References for further reading are also included. 


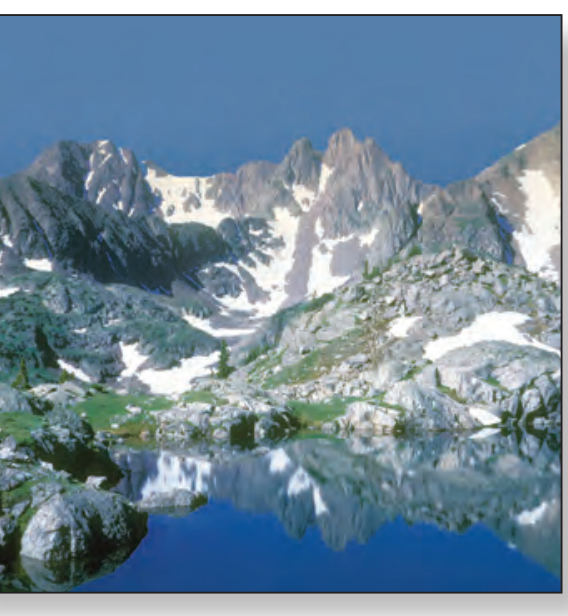

Overview of This Report.

Introduction.

Geological Story of the Blue River Region

Laying the Foundation—Proterozoic Basement Rocks .......................................................

Ancient Seas and Long-Vanished Mountains......................................................................11

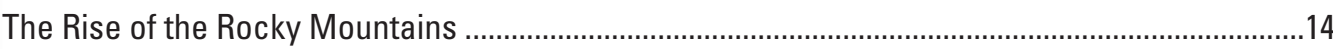

Igneous Activity and the Laramide Orogeny ...................................................................17

The Gore Fault Zone and Faults Cutting Proterozoic Rocks of the Gore Range .......................18

The Continent Pulled Apart—Development of the Northern Rio Grande Rift .................................19

The Upper Oligocene to Upper Miocene Troublesome Formation-

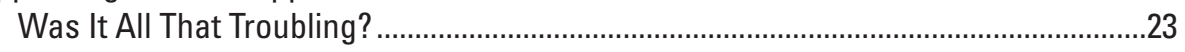

What Happened to All the Sediment That Once Filled the Blue River Valley? ........................23

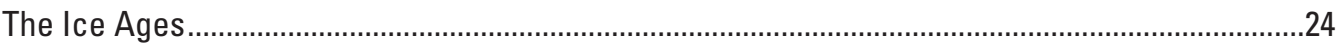

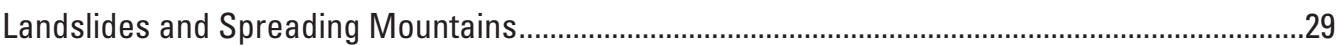

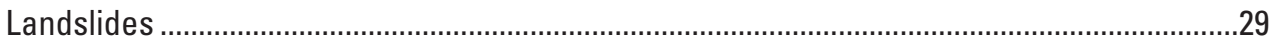

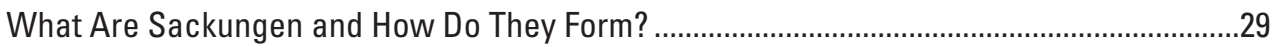

Rich Ores of the Blue River Valley Region-Their Geology and Mining History .............................31

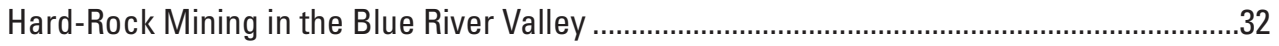

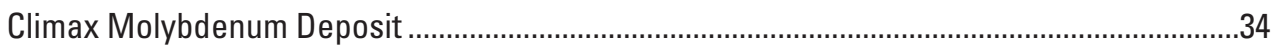

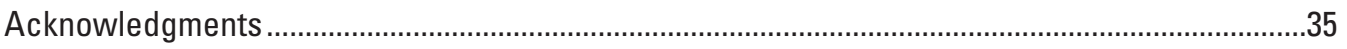

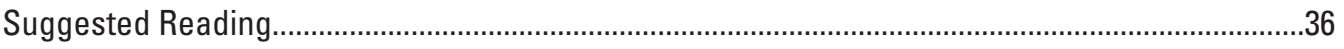

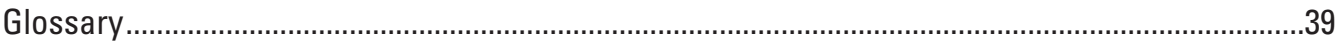

\section{Information Boxes}

1. Dating Rocks by Using Zircons......................................................................................

2. Dating Igneous Rocks by Using Radioactive Decay of Potassium to Argon ....................20

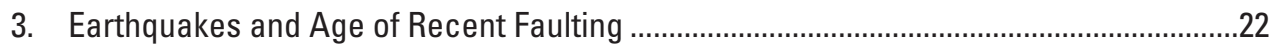

4. What Apatite Fission Tracks Tell Us about Uplift and Cooling History..............................23

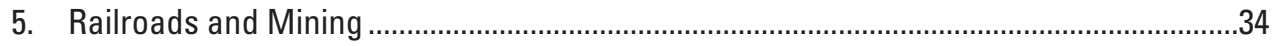




\section{Figures}

1. Photograph of cirque and tarn at the head of Boulder Creek, Gore Range.......................vi

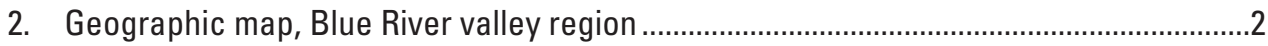

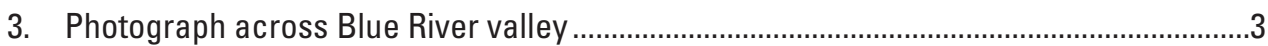

4. Diagram showing divisions of geologic time ...................................................................

5. Photograph of migmatitic biotite gneiss, Williams Fork Mountains...................................5

6. Photograph of amphibolite intruded by thin sills of granite and pegmatite dikes, Tenmile Canyon . .7

7. Simplified geologic map of the Blue River valley region..................................................

8. Stratigraphic column of sedimentary and igneous rocks, Blue River valley region .......10

9. Diagram of late Paleozoic Ancestral Rocky Mountain uplifts and adjacent basins

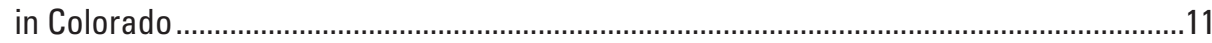

10. Schematic cross sections through the Blue River valley region ....................................12

11. Photograph of Dakota Sandstone in road cut, Interstate Highway 70 , two miles west of Williams Range thrust....

12. Photograph of black shale, lower part of Pierre Shale, below the Williams Range thrust..................................................................................

13. Photograph of Williams Range thrust fault near Keystone ............................................15

14. Photograph of late Oligocene dike of hornblende latite porphyry, Haystack Butte........16

15. Photograph of Minturn Formation and Paleoproterozoic granite juxtaposed by Gore fault, Booth Creek ...............................................................................................18

16. Diagrammatic map of Rio Grande rift........................................................................19

17. Photograph of moderately welded upper Oligocene tuff, South Brush Creek................20

18. Photograph of early morning view of the Gore Range from Ute Pass..............................21

19. Schematic east-west cross section showing proposed relationship of down-to-the-east normal faults, Blue River valley ......................................................22

20. Map showing extent of Pleistocene glaciers, Blue River valley region..........................25

21. Photograph of unconsolidated till of Bull Lake glaciation, Dillon Reservoir....................26

22. Photograph of unconsolidated till of Pinedale glaciation, Dillon Reservoir ....................26

23. Photograph of active rock glacier, South Rock Creek, Gore Range ...............................27

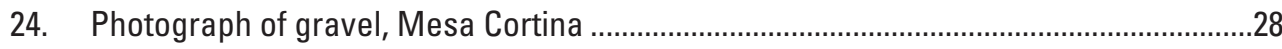

25. Photograph of sackungen near crest of southern Williams Fork Mountains...................30

26. Schematic cross section showing development of sackungen,

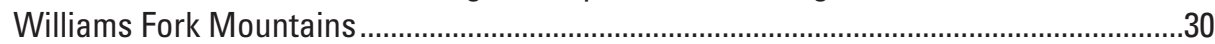

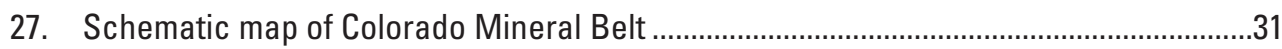

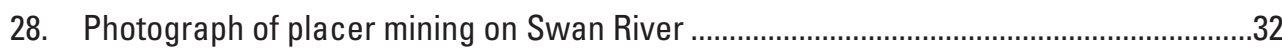

29. Photograph of Wellington mine on French Gulch ...........................................................33 


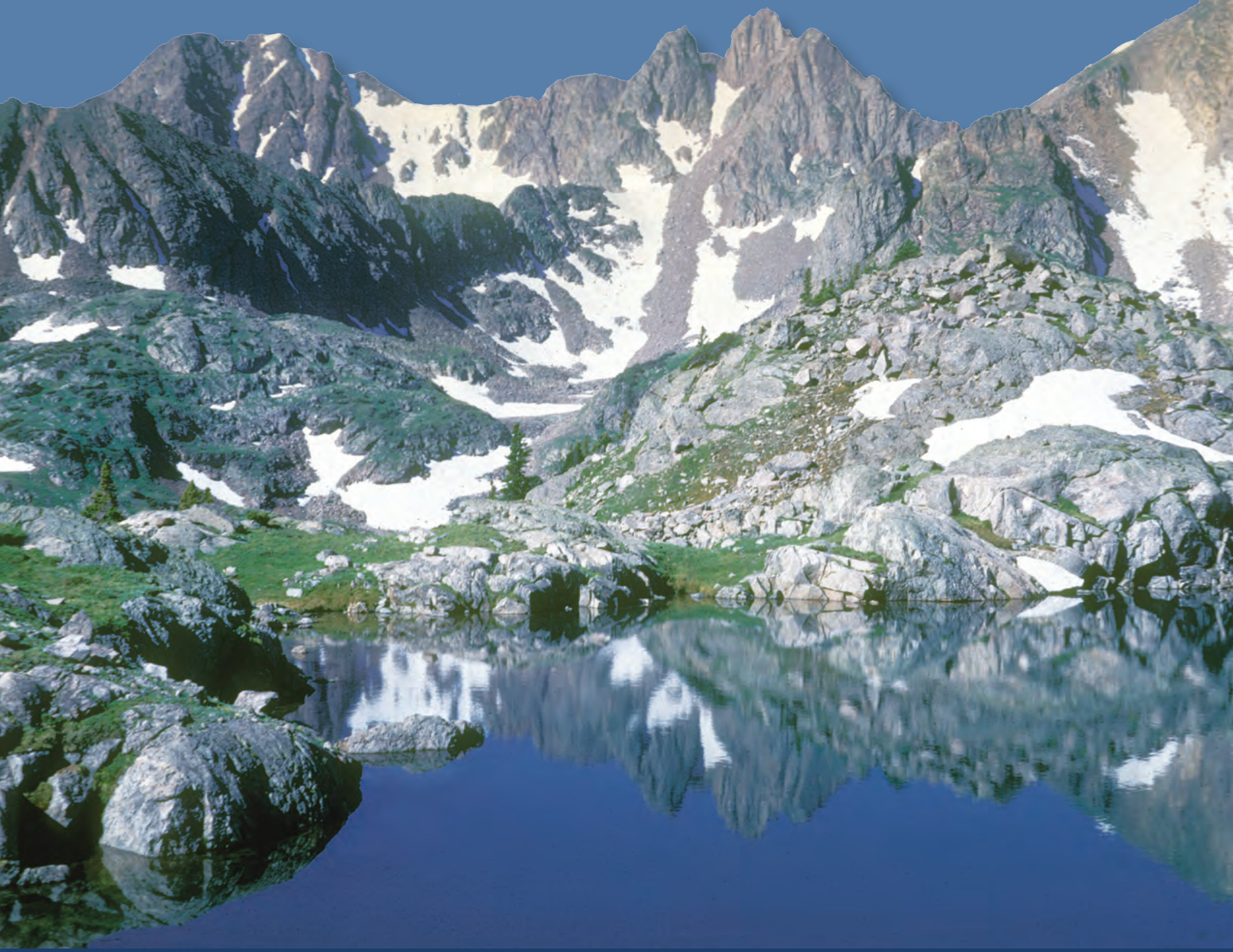

Figure 1. View to the northwest of a cirque and glacial lake (tarn) at the head of Boulder Creek in the Gore Range. The bedrock in this area is 1700-million-year-old Cross Creek Granite. 


\title{
Mountains,

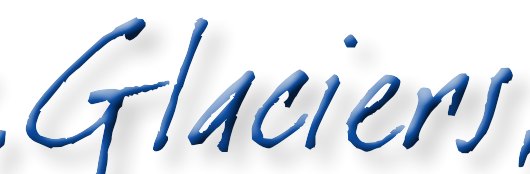 \\ and Mines The Geological Story of the Blue River Valley, Colorado, and Its Surrounding Mountains
}

\author{
By Karl S. Kellogg, Bruce Bryant, and Ralph R. Shroba
}

\section{Introduction}

Perhaps no other place in Colorado contains such a variety of rocks and geological features as the Blue River region, and this guide offers a wonderful opportunity to explore the geology of this beautiful mountain area. Some of the oldest rocks in the central Rocky Mountains make up the high peaks of the Gore Range (fig. 1), Tenmile Range, and western Front Range, and a variety of younger rocks and geological deposits record a geological story that is beautifully displayed at many places in the Blue River region. This guide will help you turn the pages of this story.

An early influx of settlers in the latter half of the 19th century is closely tied to the geology of the region. Placer and hard-rock mining was the first major economic draw in several areas, such as around the towns of Breckenridge, Montezuma, and Kokomo (the latter town is now buried under the mine tailings of the Climax molybdenum mine). More recently, a multibillion-dollar ski industry, as well as many other outdoor activities, attracted a new wave of settlers who fueled rapid population growth. Several world-class ski resorts (such as Keystone, Copper Mountain, Breckenridge, and Arapahoe Basin) are situated in the Blue River drainage basin. Dillon Reservoir and Green Mountain Reservoir, behind dams constructed on the Blue River in the early 1960s, provide boating and fishing in the summer. The old Dillon town site lies under the water of Dillon Reservoir; the town was moved to its present location during dam construction (fig. 2).

From its headwaters near Hoosier Pass, the Blue River flows approximately 50 miles north through or near the towns of Breckenridge, Frisco, and Silverthorne to join the Colorado River at the town of Kremmling (fig. 2). Tenmile Creek, with headwaters near Fremont Pass, is a major tributary of the Blue River. The Blue River valley is flanked on the west by the rugged Gore Range and on the east by the Williams Fork Mountains, which is actually the large western ridge of the more extensive Colorado Front Range; the impressive Tenmile Range lies between Tenmile Creek and the Blue River.
Summit County, whose county seat is Breckenridge, lies entirely within the drainage of the Blue River, and there is a good reason that this county has such a lofty name. The lowest point in the county, along the lower Blue River, is more than 7,500 feet above sea level, and a large expanse of the county lies in the alpine zone above tree line (approximately 11,500 feet elevation). Two of Colorado's "fourteeners" (peaks more than 14,000 feet high) lie along the Continental Divide on the Summit County-Park County line (fig. 2): Torreys Peak (14,267 feet) and Grays Peak (14,278 feet). These are the only two fourteeners, out of about 53 total in Colorado, that lie along the Continental Divide. In fact, Grays Peak is the highest point on the Continental Divide in North America. From many places in the Blue River valley, the distinctive double summits of Grays and Torreys Peaks are visible. The county contains one other fourteener, Quandary Peak (14,265 feet), in the Tenmile Range. Many old mining roads cross the high country and are open to four-wheel-drive vehicles in the summer and make good routes for ski touring in the winter. A gravel road (not plowed in winter) follows an abandoned railroad grade over the Continental Divide at Boreas Pass.

The Gore Range forms one of Colorado's most impressive and rugged alpine environments, with steep, rocky peaks, glacially carved cirques, and numerous high mountain lakes (fig. 1). Mt. Powell (13,448 feet), the highest peak in the range, gives way to the north to a gentler and lower meadowy ridge (Elliott Ridge). The high Gore Range is part of the Eagles Nest Wilderness, and most of the high country is accessible by hiking trails. The jagged Gore Range contrasts sharply with the gentle, rolling alpine meadows of the Williams Fork Mountains, despite similar rocks underlying both ranges. As we will see, there is a good geological explanation for this puzzling contrast in topography. 

$106^{\circ} 30^{\prime}$

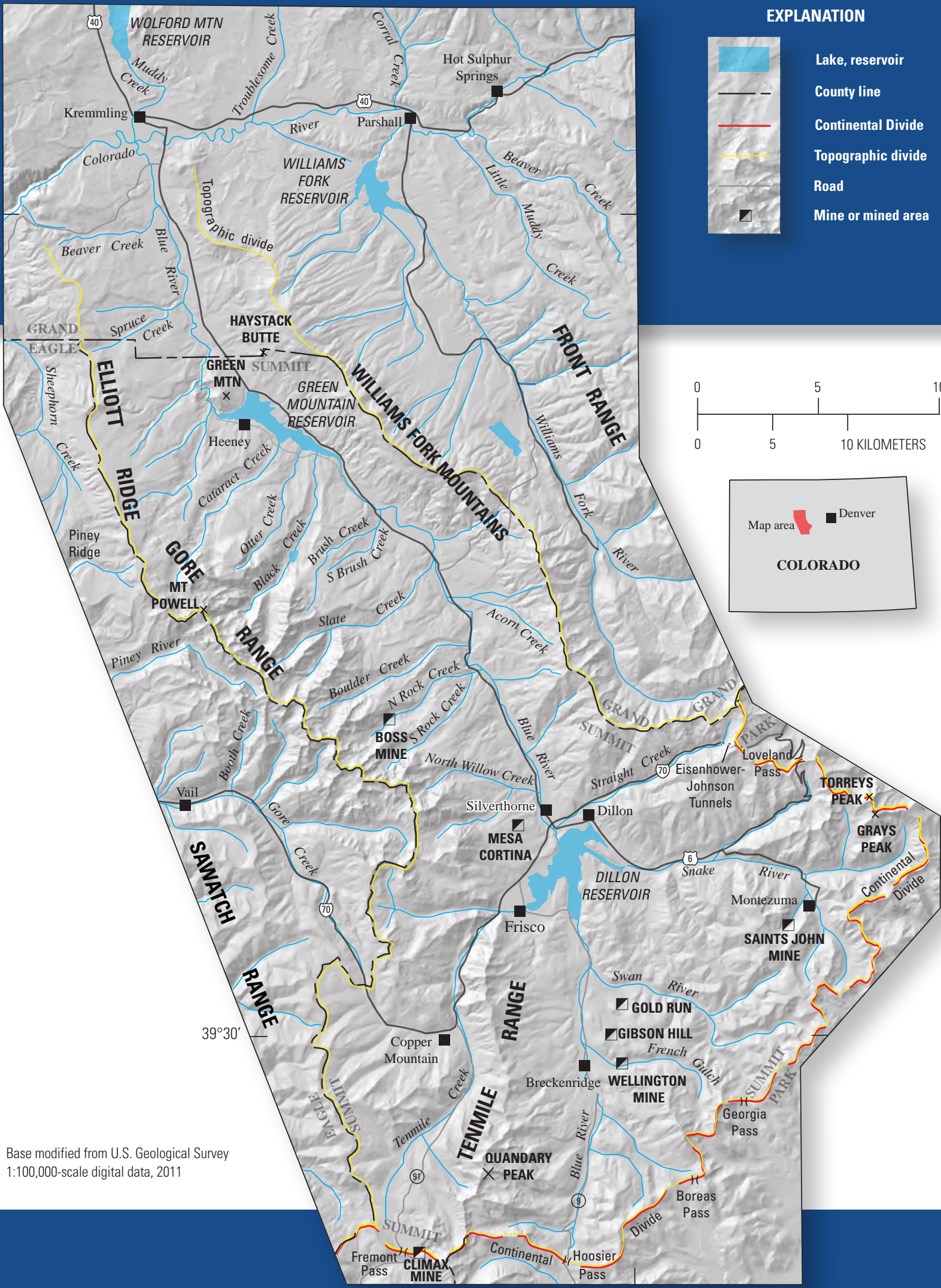

Figure 2. Geography of the Summit County region. In the southeast portion of the map, county boundaries follow the Continental Divide. 
This booklet provides an overview of the geology of the Summit County region, which includes the entire Blue River drainage basin (fig. 2). Many studies have contributed to our understanding of this geologic story. In particular, the reader is referred to Kellogg and others $(2008,2011)$ and Ruleman and others (2011) for a more thorough discussion of the geology, supported by detailed geological maps and cross sections.

The geologic map and cross sections used in this report were simplified from these sources. Because understanding the geological story requires a familiarity with some geologic terms and concepts, a glossary at the end of this booklet defines geological terms. References to more detailed descriptions of the geology of the region are listed at the end of this booklet.

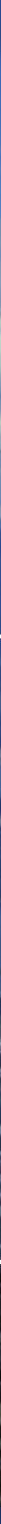

Figure 3. View to the north of the Blue River valley, taken from the north end of the Tenmile Range. The Williams Range thrust (mostly covered by landslide debris) on the west flank of the Williams Fork Range (western part of the more extensive Front Range) is shown, as is the Blue River normal fault at the eastern edge of the Gore Range. Interstate 70 is visible in the right part of the photo. The edge of the town of Frisco is seen in front of an arm of Dillon Reservoir. 


\section{Geological Story of the Blue River Region}

The geological story of the Blue River region stretches for 1780 million years, almost 40 percent of the age of the Earth. This lengthy history is divided into six major chapters:

1. Proterozoic $\square$ history, mostly represented by an early Proterozoic (Paleoproterozoic $\square$ ) period of thick sedimentation and widespread volcanism, followed by voluminous intrusions of mostly granitic magma, and recrystallization (during metamorphism) and deformation of the deeply buried sedimentary and igneous rocks. Later in the Proterozoic Era (during the Neoproterozoic $\square$ ), mostly granitic magma locally intruded the earlier igneous and metamorphic rocks.

2. Following a poorly understood late Proterozoic (Neoproterozoic $\square$ ) period of uplift and deep erosion of the Proterozoic metamorphic and intrusive rocks to a vast surface of low relief, a long period of sedimentation throughout the entire region transpired from Late Cambrian $\square$ to Late Cretaceous $\square$ time (fig. 4). Much of this sedimentation was on the floors of ancient seas, although this part of the story was interrupted by a late Paleozoic $\square$ period of mountain building, producing the longsince-eroded "Ancestral Rocky Mountains."

3. Late Cretaceous $\square$ to early Tertiary $\square$ mountain building, called the "Laramide orogeny," and thick accumulation of debris shed off the rising mountains, during a period of crustal contraction (shortening). It was during the Laramide orogeny that the early roots of the present Rocky Mountains were formed, although they were subsequently much modified.

4. Middle to late Tertiary $\square$ basin development (including development of the rift underlying the Blue River valley) during pulling apart of the Earth's crust, followed by renewed uplift of the southern Rocky Mountain region.

5. The ice ages, times of global cooling, extensive glaciation, and deep erosion. Included are other factors that changed the landscape during the Quaternary Period $\square$, such as widespread landsliding and gravitational spreading of mountains.

6. Lastly, a section is devoted to the fascinating mining history of the region and the geology of the ores that fed the mines.

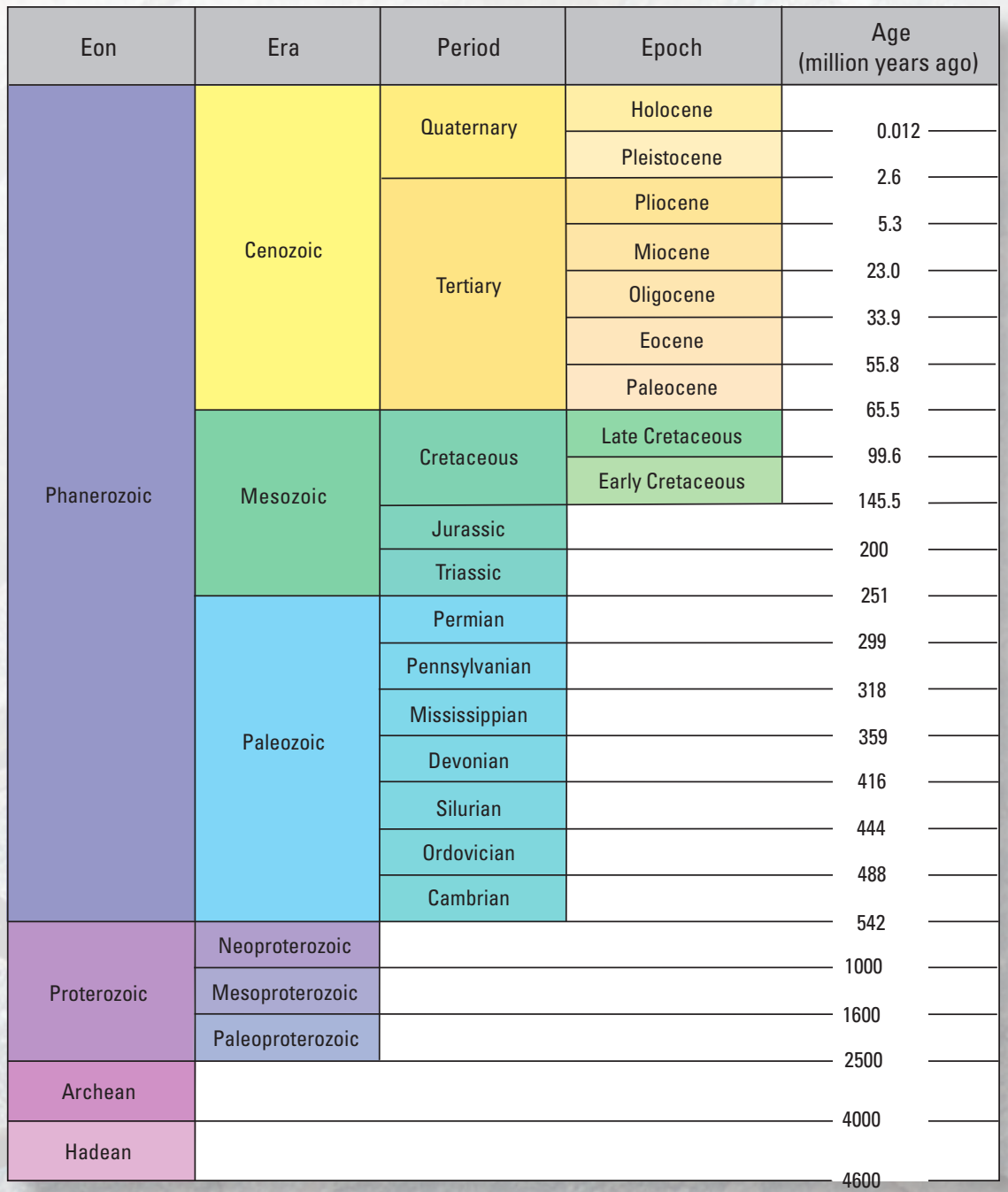

Figure 4. Divisions of geologic time. Ages from U.S. Geological Survey Fact Sheet 2010-3059 (U.S. Geological Survey Geologic Names Committee, 2010). 


\section{Laying the Foundation-Proterozoic Basement Rocks}

During part of the Paleoproterozoic Era (between about 1780 and 1740 million years ago), thick marine sediments and volcanic rocks of various composition accumulated in deep basins in the northern Colorado region. Keep in mind that the Earth is about 4600 million years old, so these rocks were deposited when the Earth was 60 percent as old as it is now. We know almost nothing about the history of the area before this time because no older rocks are preserved. During an episode of rock deformation (that is to say, an orogeny) that lasted about 110 million years, these layered rocks were pervasively folded, stretched, and intruded by large molten bodies of magma, most of which solidified into granite. These processes occurred many miles deep in the Earth's crust, where elevated heat and pressure cause most minerals to form into larger grains, or even to react chemically to form new minerals. At these extreme conditions, rocks deform in a ductile manner, much like taffy. The combination of recrystallization and intense deformation produced metamorphic rocks and destroyed most evidence of the types of rocks from which they were derived.
The metamorphic rocks include quartz-feldspar gneiss (possibly metamorphosed volcanic tuff), biotite gneiss and schist (metamorphosed sandstone and shale), amphibolite and hornblende-plagioclase gneiss (probably metamorphosed basalt and andesite, and sediments derived from these volcanic rocks), minor quartzite, and "calc-silicate gneiss" (metamorphosed limey or calcareous sediments, including limestone). In most places, the metasedimentary and igneous rocks are now complexly interlayered, mixed, and deformed, as is shown in figure 5.

Figure 5 (below). Migmatitic biotite gneiss on east side of crest of Williams Fork Mountains. The light-colored, pink igneous phase grades into coarse-grained pegmatite clots in the upper part of the image. This pink phase is interpreted to have formed by partial melting of the darker biotite gneiss. Pencil is about 7 inches long for scale.

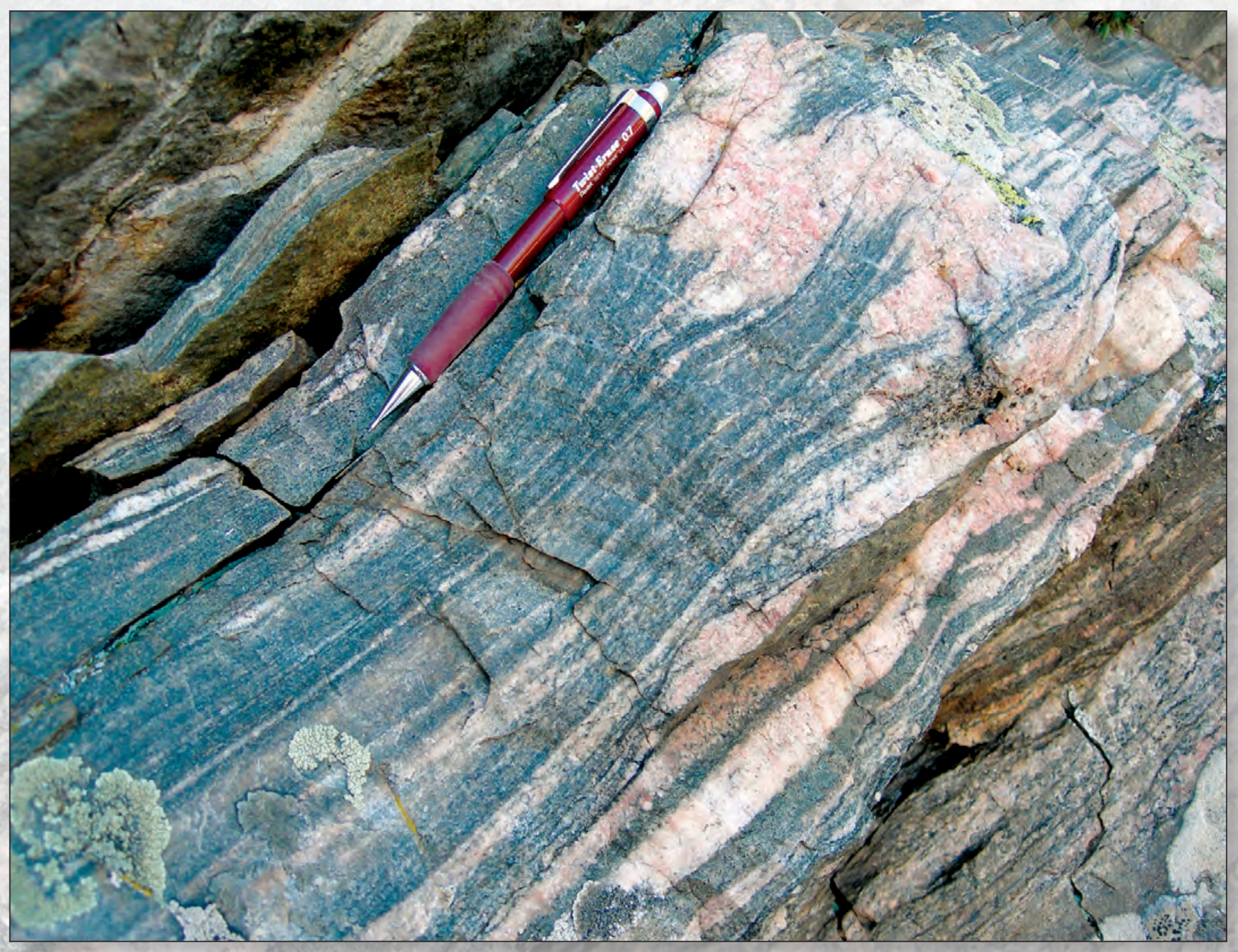




\section{Onformation Box $\%$ \\ Dating Rocks by Using Zircons}

Tiny zircon grains are found in very small quantities in virtually all rocks of granitic composition, including metamorphic rocks. These zircons can be used to date the time that the igneous and metamorphic rocks formed, using the radioactive decay of isotopes of uranium to isotopes of lead. This decay occurs at a precisely known rate, so that if we know the ratios of the various isotopes of lead and uranium in the zircons (measured on an instrument called a mass spectrometer), we can calculate the age of the rock. Zircons in igneous rocks record the time at which the rock cooled from a magma, when the zircons first crystallized. However, the zircon grains in most metamorphosed sedimentary rocks were washed in from some distant source, so their age (1785-1740 million years old in the Blue River region) is the age of the rock that was eroded and provided the zircon-bearing sediment. This age, therefore, represents only the maximum age of deposition of the sediment (later to become a metamorphic rock) in which the zircons are found. Zircons are tough little minerals, so metamorphism does not change them very much.

Many of the more quartz- and feldspar-rich metasedimentary rocks, such as biotite gneiss, partially melted and then formed a rock called migmatite (fig. 5), which in most cases displays alternating light and dark layers. The light layers are a melt phase, produced from partial melting of the darker layers (the remaining original rock) and have a composition resembling granite. In some migmatites, the light-colored melt phase that was injected between the layers of metamorphic rocks came from a more distant source (fig. 6). The degree of migmatite formation decreases toward the northwest, such that migmatites are rare among the metamorphic rocks north of Green Mountain Reservoir (fig. 7). Zircon dates from several localities in the region indicate that metamorphism peaked and migmatites formed about 1697 million years ago (refer to the Denver West map by Kellogg and others, 2008, for a more detailed discussion of migmatites and their age).

Contemporaneous with or closely following the approximately 1700-million-year-old metamorphic and deformational event, extensive batholiths and smaller bodies of mostly granodiorite and granite (called stocks) intruded the older metamorphic rocks. For example, the approximately 1700 million-year-old Paleoproterozoic Cross Creek Granite (figs. 7 and 8) underlies large areas of the Gore Range, and other stocks and batholiths ranging in composition from gabbro to granite intruded between 1725 and 1710 million years ago over a widespread region in Colorado, including the Front Range and Sawatch Range.
The Paleoproterozoic basement of the Front Range region was extensively modified during a second period of deformation, heating, and intrusion of mostly granitic rocks about 1400 million years ago. Plutons that intruded during this orogeny are widespread in the Front Range region; several are mapped in the southern Tenmile Range near the Climax mine and near the Eisenhower-Johnson Tunnels on Interstate 70.

Almost all basement rocks are cut by irregular-shaped dikes of light-colored, very coarse grained intrusive rocks called pegmatites. These dikes, composed almost entirely of feldspar, quartz, and minor amounts of biotite (black mica) and in some places muscovite (clear mica), solidified from granitic melts where water and other volatile phases concentrated the last liquid left during cooling and solidification. Small pegmatite bodies and dikes are shown in figures 5 and 6 .

The Proterozoic rocks of the Front Range and Gore Range are transected by northeast- to east-trending, discontinuous zones of intense deformation that formed during both the approximately 1700-million-year-old and 1400-million-year-old episodes of deformation and granite intrusion. These zones, called shear zones, are analogous to faults because differential movement of rocks takes place across them. However, along a fault, movement takes place along a sharp break; in a shear zone, movement between rocks on either side is distributed over a wide zone. Shear zones generally form at depth, where temperature and pressure are high enough that rocks are no longer brittle but act in a ductile fashion, like soft putty. The mineral grains in these zones were typically reduced in size and sheared into parallel layers. In extreme cases of shearing and grain-size reduction, a hard, very fine grained rock called mylonite resulted. The Tupps Creek shear zone in the northern Gore Range (fig. 7) is a particularly well exposed shear zone. 


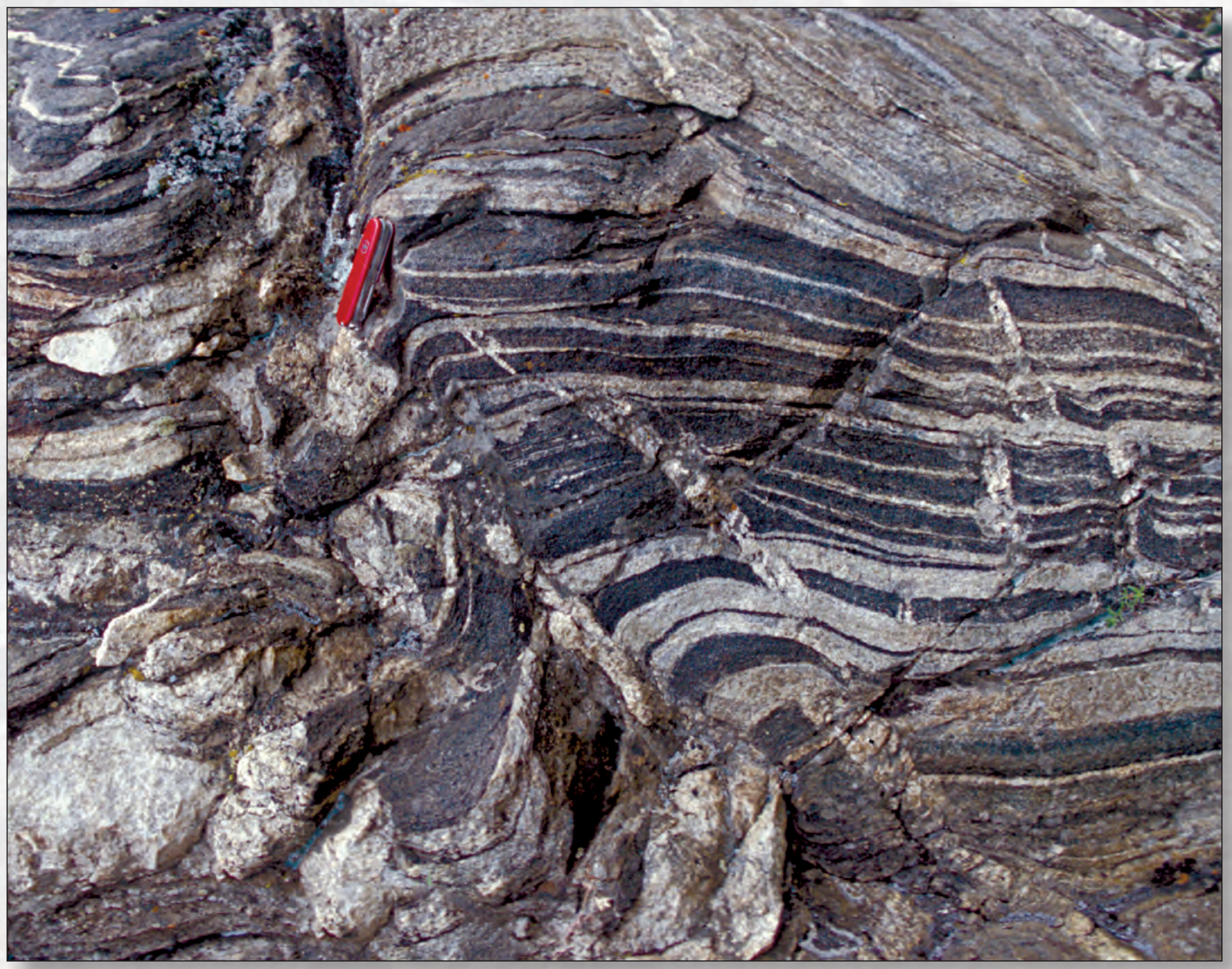

Figure 6. Amphibolite intruded by numerous thin sills of granite, in turn cut by small pegmatite dikes. Nearby foliated granite, correlated with the granite sills, was dated at about 1755 million years old (Kellogg and others, 2011). Outcrop in Tenmile Canyon (Officers Gulch). Knife is about 3 inches long. 


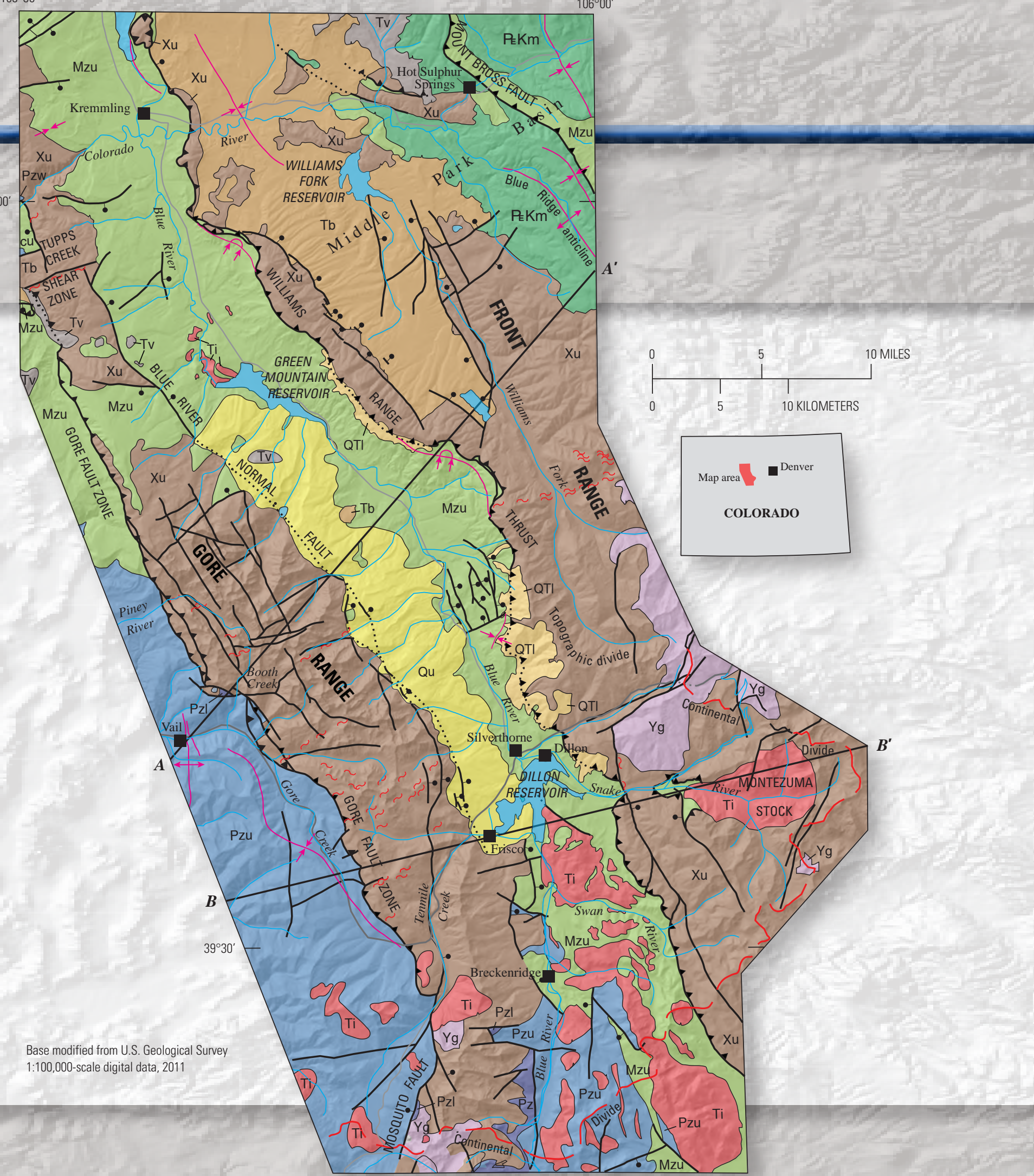


Geology of the Blue Riven Valley Region

\section{EXPLANATION}

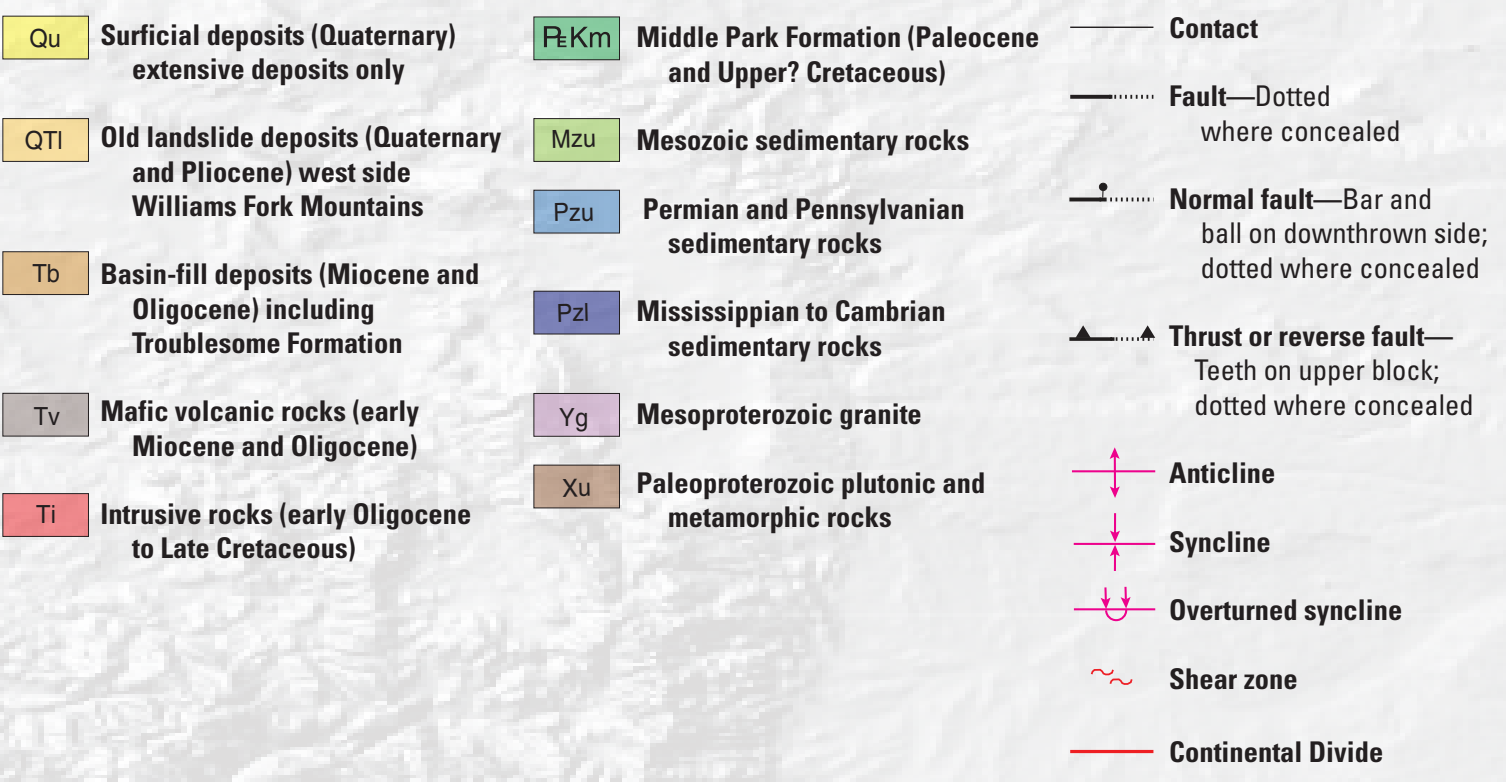

Figure 7 (pages 8 and 9). Simplified geology of the Blue River valley region, based mostly on detailed maps of Kellogg and others $(2008,2011)$ and Ruleman and others $(2011)$, and references therein. 


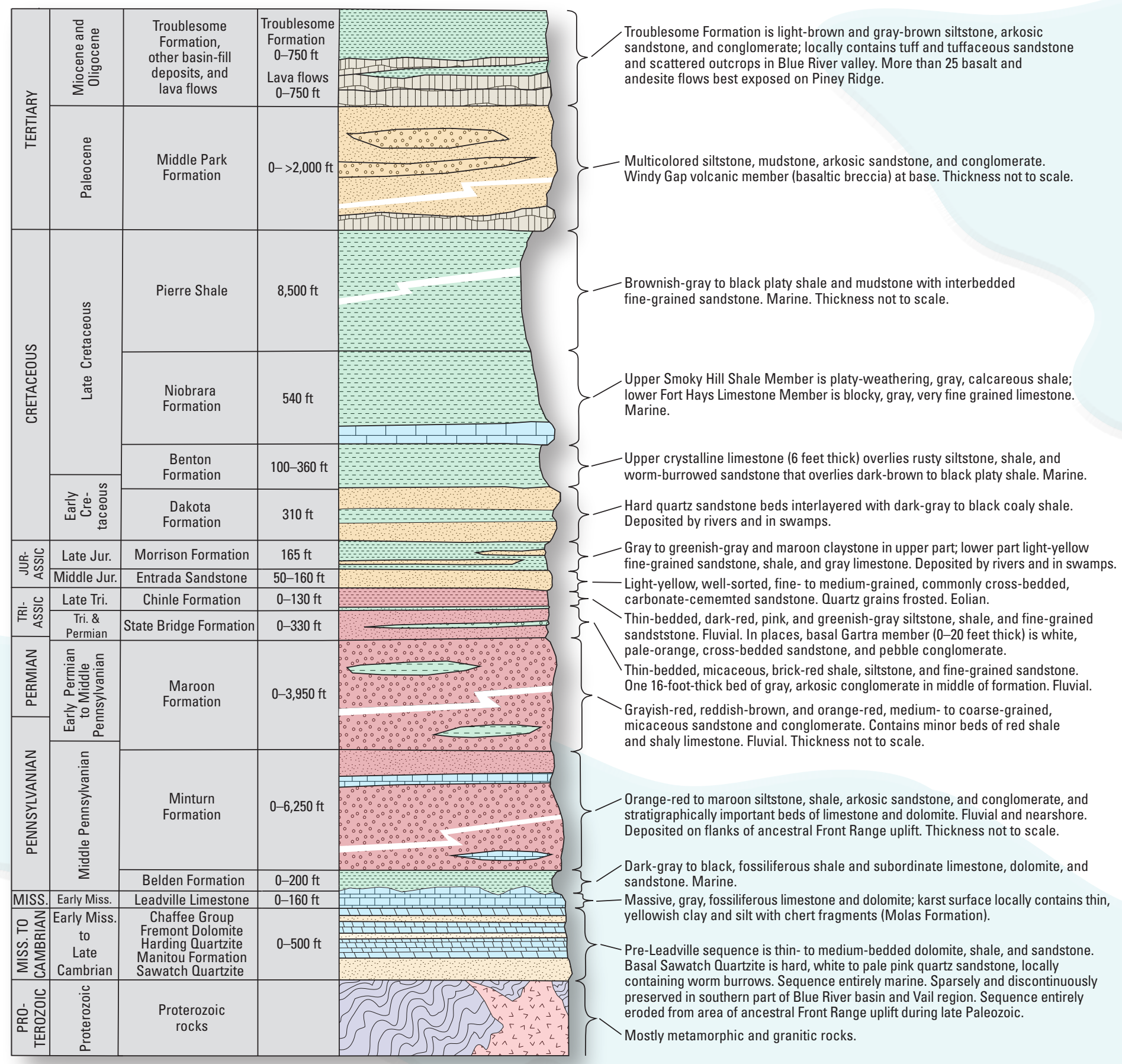

Figure 8. Stratigraphic column of sedimentary and igneous rocks in the Blue River valley region. Cretaceous and Tertiary intrusive rocks, and rocks and deposits younger than the Troublesome Formation, are not shown. The Middle Park, Pierre Shale, Maroon, and Minturn Formations may be thicker than represented in the stratigraphic column. 


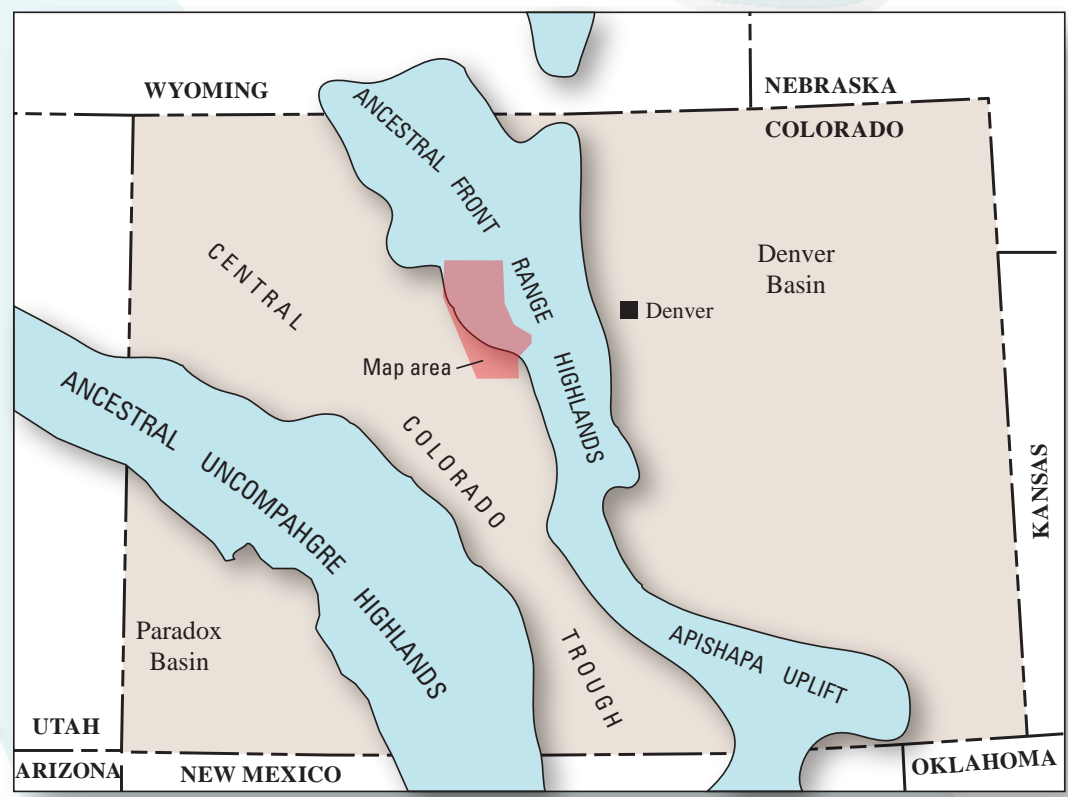

Figure 9. Late Paleozoic Ancestral Rocky Mountain uplifts and adjacent basins in Colorado. Area of figure 7 outlined in red.

\section{Ancient Seas and Long-Vanished Mountains}

Sometime during the latest Proterozoic Era, a widespread and poorly understood period of uplift and erosion exposed deep levels of the basement rocks across a nearly flat surface that extended over much of what is now North America. Shallow seas covered this surface during most of the time between deposition of the Upper Cambrian Sawatch Quartzite and Middle Pennsylvanian Belden Formation (fig. 8), which are well exposed near Minturn, just west of the map area. The surface at the base of these sedimentary rocks, just above the underlying, much-older basement rocks, is referred to as the Great Unconformity.

Life forms proliferated in the Cambrian Period. Although some soft-bodied organisms lived before the Cambrian Period, it was not until the Paleozoic Era that organisms generally developed hard body parts that were well preserved as fossils.

Uplift of the Ancestral Front Range, one of many late Paleozoic uplifts in the western and central United States (collectively called the Ancestral Rocky Mountains), began during the Middle Pennsylvanian Epoch (fig. 9). As the rocks rose, nearly all pre-Pennsylvanian sedimentary rocks from the upper Blue River valley area were eroded, with the exception of limited areas of Ordovician to Mississippian rocks south of Breckenridge (fig. 7, unit PzI), which were just off the western flank of the Ancestral Front Range (fig. 9). Rocks as old as the Cambrian Sawatch Quartzite are beautifully exposed in Eagle County near Minturn, just southwest of Vail. In the northern Gore Range, which lies near the central part of the Ancestral Front Range, all rocks older than the Upper Jurassic Morrison Formation were completely eroded. Coarse sediment (sand, cobbles and boulders) was shed southwestward into the flanking Central Colorado trough (fig. 9), forming coarse alluvial fans and fluvial (river) deposits that later solidified to form the Pennsylvanian Minturn Formation and overlying Pennsylvanian and Permian Maroon Formation (fig. 7, unit Pzu; fig. 8). These two thick formations are exposed throughout large areas in southwestern Summit County west of the Gore fault zone. Deposition of the coarse sediment of the Minturn Formation was interrupted periodically by incursions of the sea, as demonstrated by marine limestone interbedded with the sandstones. Some of the limestone subsequently altered to dolomite by the addition of magnesium derived from hot groundwater, probably during the Laramide orogeny (which we will discuss in the next section). The Maroon Formation contains almost no limestone. The grain size of the clastic deposits (siltstone, sandstone, and conglomerate) decreases toward the axis of the Central Colorado trough (fig. 9), in which a saline sea with limited circulation deposited thousands of feet of evaporite (halite or rock salt, and gypsum) at the same time that the Minturn Formation was deposited.

Also at the same time, sediments similar to those of the Minturn and Maroon Formations were shed eastward off the Ancestral Front Range uplift. Those rocks are now exposed along the eastern margin of the Front Range, forming the Fountain Formation, which makes up the prominent Flatirons near Boulder, Red Rocks Amphitheatre west of Denver, the spectacular rock formations of Roxborough State Park south of Denver, and the spires of the Garden of the Gods near Colorado Springs.

The Gore fault zone, which lies along the west side of the Gore Range (figs. 7 and 10), is actually a complicated array of intersecting steep faults that defines the approximate eastern structural boundary of the Central Colorado trough. The Gore fault zone has had a protracted tectonic history, beginning at least as early as the early Paleozoic, and perhaps even the Precambrian, although most deformation along this zone is Laramide in age. 

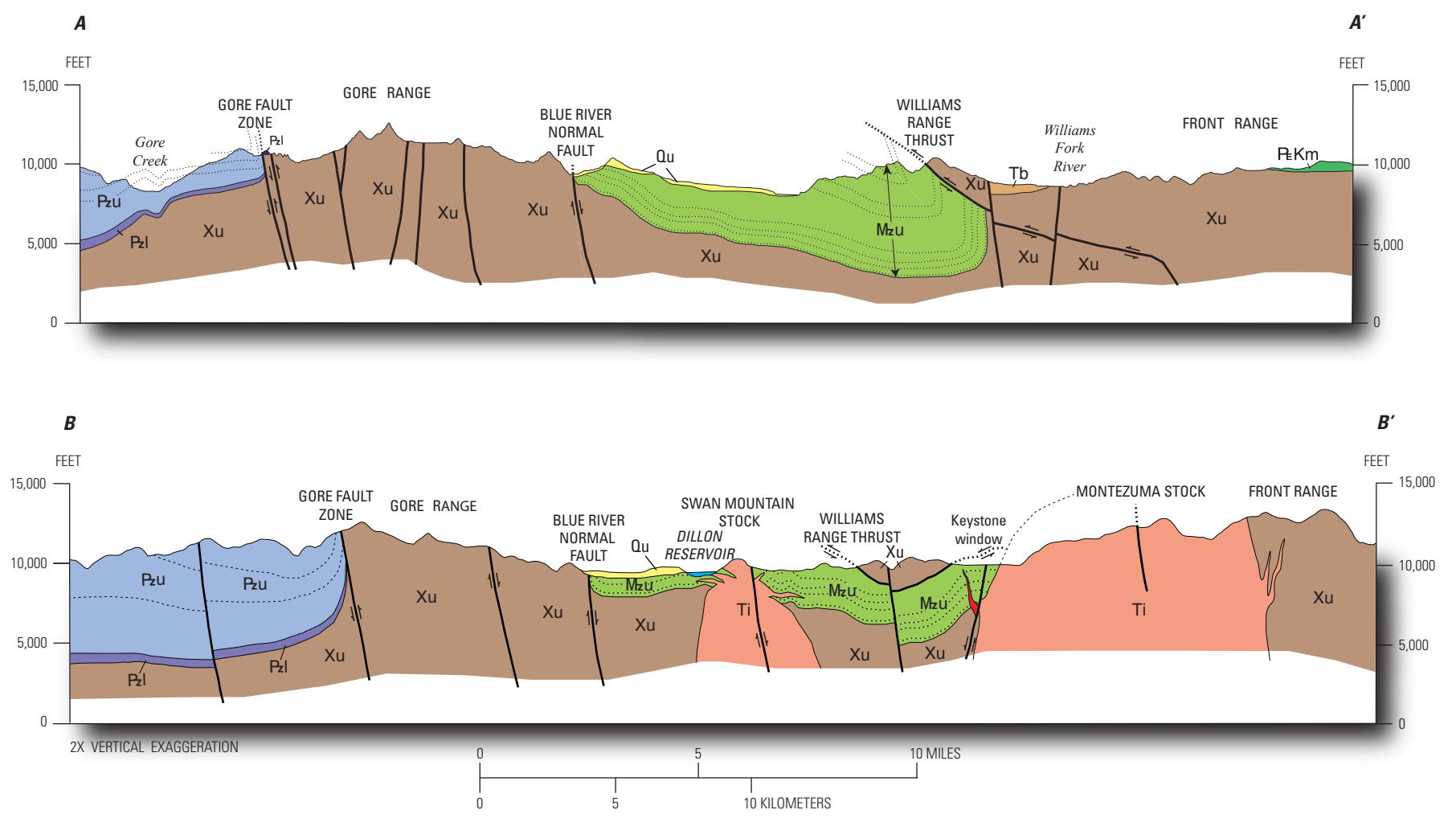

EXPLANATION

\begin{tabular}{|c|c|}
\hline Qu & Quaternary surficial deposit \\
\hline $\mathrm{Tb}$ & Tertiary basin fill \\
\hline $\mathrm{Ti}$ & Tertiary intrusive granite \\
\hline $\mathrm{Mzu}$ & Mesozoic rock undifferentiated \\
\hline $\mathrm{PEKm}$ & $\begin{array}{l}\text { Paleocene and Upper Cretaceous } \\
\text { Middle Park Formation }\end{array}$ \\
\hline
\end{tabular}

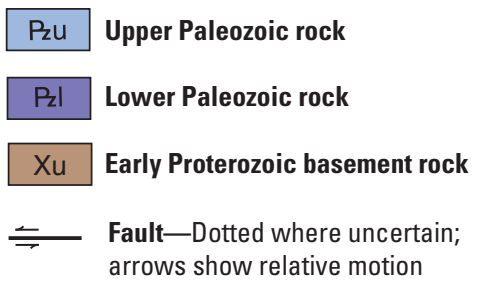

Figure 10. Cross sections (slices through the Earth's upper crust) running generally southwest to northeast through the Blue River valley region; see figure 7 for lines of section $A-A^{\prime}$ and $B-B^{\prime}$. Vertical exaggeration is 2 , which increases angle of dip on structures. Cross sections are approximately twice as long as the line of section shown in figure 7 . The Mesozoic rocks are as old as the Late Triassic Chinle Formation and as young as the Upper Cretaceous Pierre Shale. The upper Paleozoic (an informal term) here refers to Mississippian through Permian rocks; lower Paleozoic (also an informal term) here refers to Cambrian through Devonian rocks.

The land of the Ancestral Front Range was above sea level, and ongoing erosion exposed basement rock until the Jurassic Period, when the region once again was eroded to a near-sea-level planar surface and the near-shore deposits of the Upper Jurassic Morrison Formation, deposited by rivers and in lagoons, covered the entire region (figs. 8 and 9); the Morrison Formation lies directly on Proterozoic rocks in the northern Gore Range. The Morrison Formation is famous for the many dinosaur fossils that have been discovered in it, most famously in Dinosaur National Monument in northwestern Colorado and northeastern Utah. The quartz sandstones and interbedded carbon-rich shales of the Lower Cretaceous Dakota Sandstone (fig. 11), which lie above the Morrison Formation, represent deposits along beaches and slow-moving rivers, and in swamps. The Dakota Sandstone, which forms "hogbacks" (sharp, rocky ridges) west of Denver, in many places is a valuable petroleum-reservoir rock. Gradual sea-level rise (accompanied in some places by tectonic subsidence beginning in the late Early Cretaceous Epoch) caused inundation of the entire region by the vast Late Cretaceous Western Interior Seaway that covered much of the central part of North America. About 9,000 feet of marine strata, mostly shale and minor limestone and sandstone (Benton Group, Niobrara Formation, and the thick Pierre Shale) were deposited in the seaway (fig. 12). 


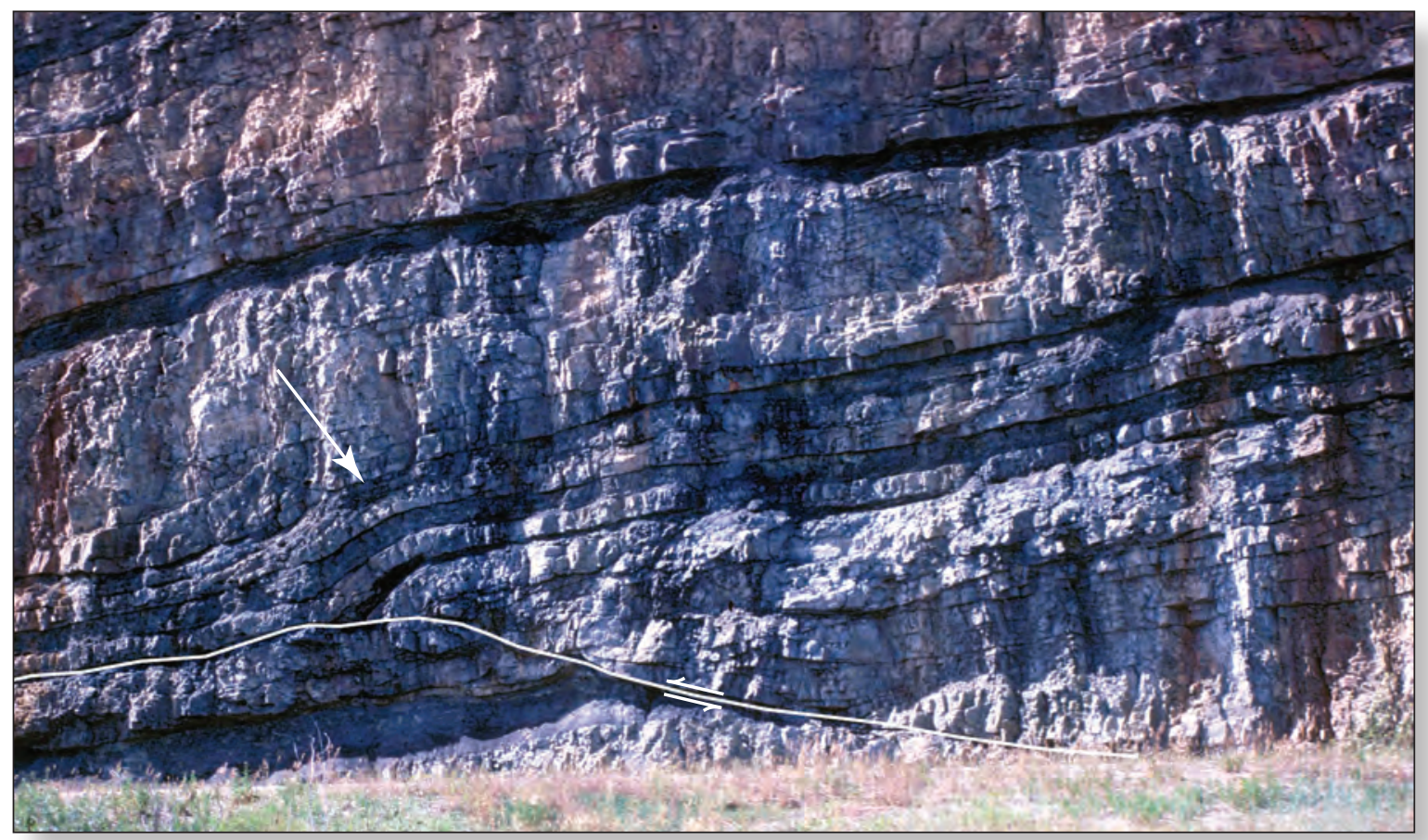

Figure 11. Dakota Sandstone exposed in road cut along Interstate Highway 70, two miles west of the Williams Range thrust. The small west-directed thrust fault (marked by white line showing relative motion along it) is similar to the much larger Williams Range thrust to the east. Note the small fold (steepened beds marked by arrow) above the thrust plane. View is to the northwest. Distance across road cut in photo is about 60 feet.

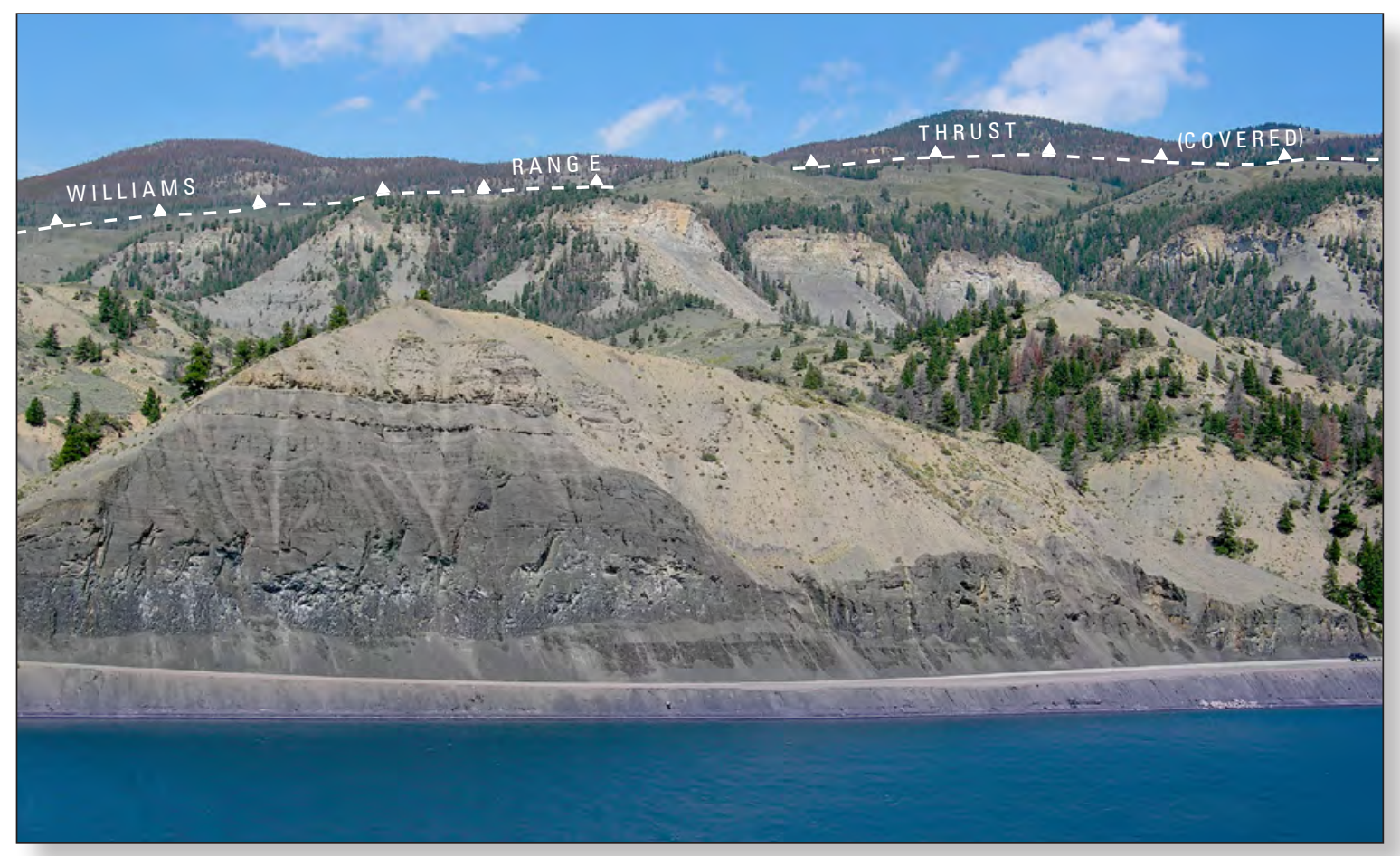

Figure 12. Black shale of the lower Pierre Shale below the Williams Range thrust. Prominent cliff just below the thrust is Hygiene Sandstone Member of the Pierre Shale. Due to weathering, the sandstone forms pale yellowish talus which in many places slides downhill to cover underlying shale. The hill in the foreground also contains thin sandstone beds near the top. The trace of the Williams Range thrust is shown by the dashed line with teeth; rocks above the thrust have moved towards the observer. View is east across Green Mountain Reservoir; the vehicle on road in lower extreme right provides scale. 


\section{The Rise of the Rocky Mountains}

The Laramide orogeny, which began about 70 million years ago and ended about 50 million years ago, marked the first episode in the building of the present Rocky Mountains. This time interval straddled the end of Late Cretaceous time (when the dinosaurs disappeared) and the beginning of Tertiary time (fig. 4). The Laramide orogeny was a time of crustal contraction (shortening), uplift, faulting, igneous activity, erosion, and sedimentation in sinking marginal basins. The Laramide orogeny formed major mountains and basins in the same places where they now exist, although these early Rockies would have looked vastly different from the Rockies we see today. Some of the peaks may have been higher than present ones, and extensive erosion during the past 50 million years and deposition of thick accumulations of sediment in marginal basins resulting from this erosion have greatly modified the shape of the land.

Early stirrings of the Laramide orogeny were marked by the withdrawal of the Western Interior Seaway from the region after 69 million years ago - the age of the youngest ammonite fossils in the Pierre Shale. (The Pierre Shale is a thick marine shale and sandstone sequence that is exposed extensively in the Blue River valley, and ammonites were ocean-dwelling invertebrates, an extinct group of cephalopods related to squids, octopuses, and chambered nautili.)

A sequence of upward-coarsening rocks as young as 64 million years old documents this initial, slowly accelerating Laramide mountain uplift. This sequence is clearly exposed near Golden on the eastern side of the Front Range, but the only rocks in the northern Blue River region area that record Laramide uplift are the fine- to very coarse-grained sandstones and conglomerates of the thick Paleocene-age Middle Park Formation. This rock unit formed from sediments that were shed mostly off the small Laramide uplifts that were formed during movement of the Williams Range thrust fault and, near Hot Sulphur Springs, by movement of the Mount Bross thrust fault, another thrust fault (fig. 7). This relationship suggests that uplift and erosion may have started in the Blue River valley region about 65 million years ago - the boundary between Cretaceous and Tertiary Periods. The earliest intrusive rocks, granitic sills in the southern part of the Blue River region, were emplaced about this same time. Boulders and cobbles in the upper part of the Middle Park Formation are mainly derived from Proterozoic basement rocks, indicating that the basement was exposed during deposition of the Middle Park sediment. The basement was brought to the surface from deeper levels, largely by moving up and over the younger rocks along the thrust faults (such as the Mount Bross fault), thereby causing the highlands or uplifts and effectively locally thickening the Earth's crust.

The Laramide-age Williams Range thrust fault defines the western structural boundary of the Front Range (by convention, it is not called the Williams Fork thrust fault, after the Williams Fork Mountains, which would make more sense). Figure 11 shows a very small thrust in Dakota Sandstone in a roadcut near Dillon that provides a miniature model of the Williams Range thrust fault; like this small thrust fault, the Williams Range thrust fault dips gently or is nearly horizontal. East of Dillon, rocks above the fault have been carried at least 6 miles westward relative to rocks beneath the fault. This movement is demonstrated by a small area just west of the Montezuma stock (fig. 7), where erosion has locally cut through the basement rock above the fault, creating a "window" through which we can see the fault and the Cretaceous sedimentary rocks beneath it (fig. 13). This window is almost 5 miles east of the main exposure of the fault. The age of the thrust is suggested by its suspected connection to the Elkhorn thrust to the south, although the possible connection is obscured by Tertiary intrusive rocks and overlying surficial deposits. The Elkhorn thrust is as young as late Paleocene (about 56 million years old).

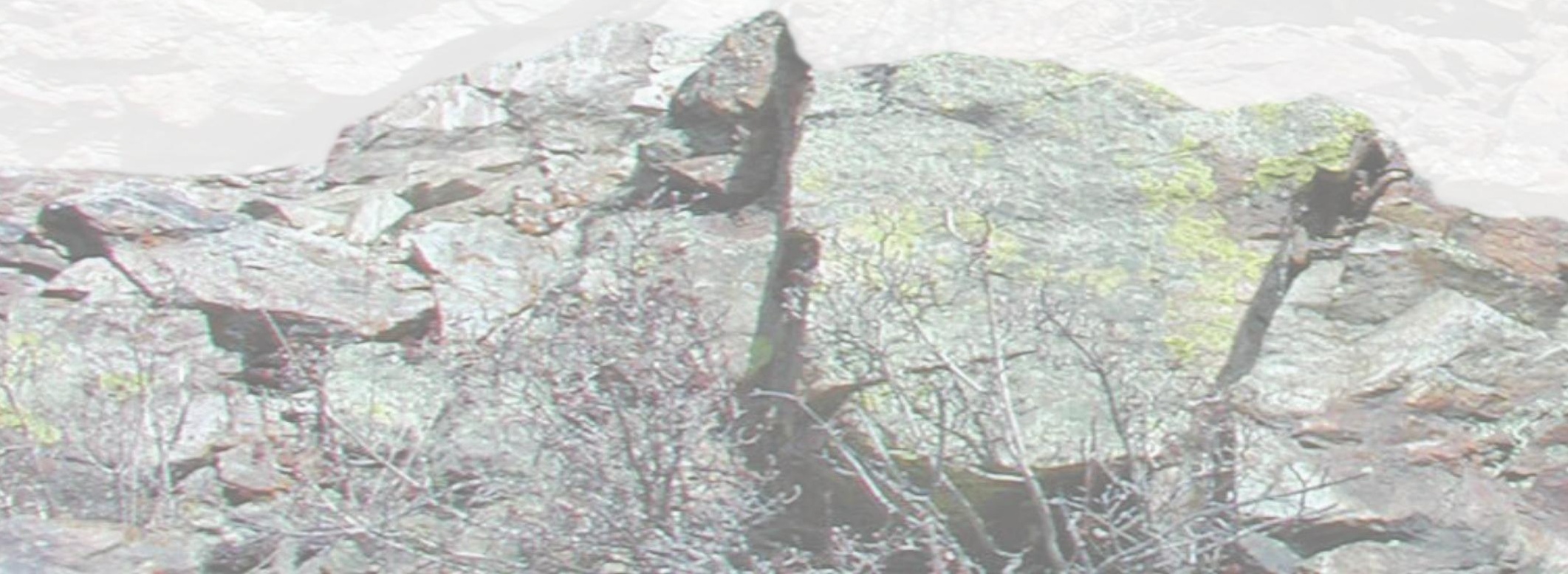




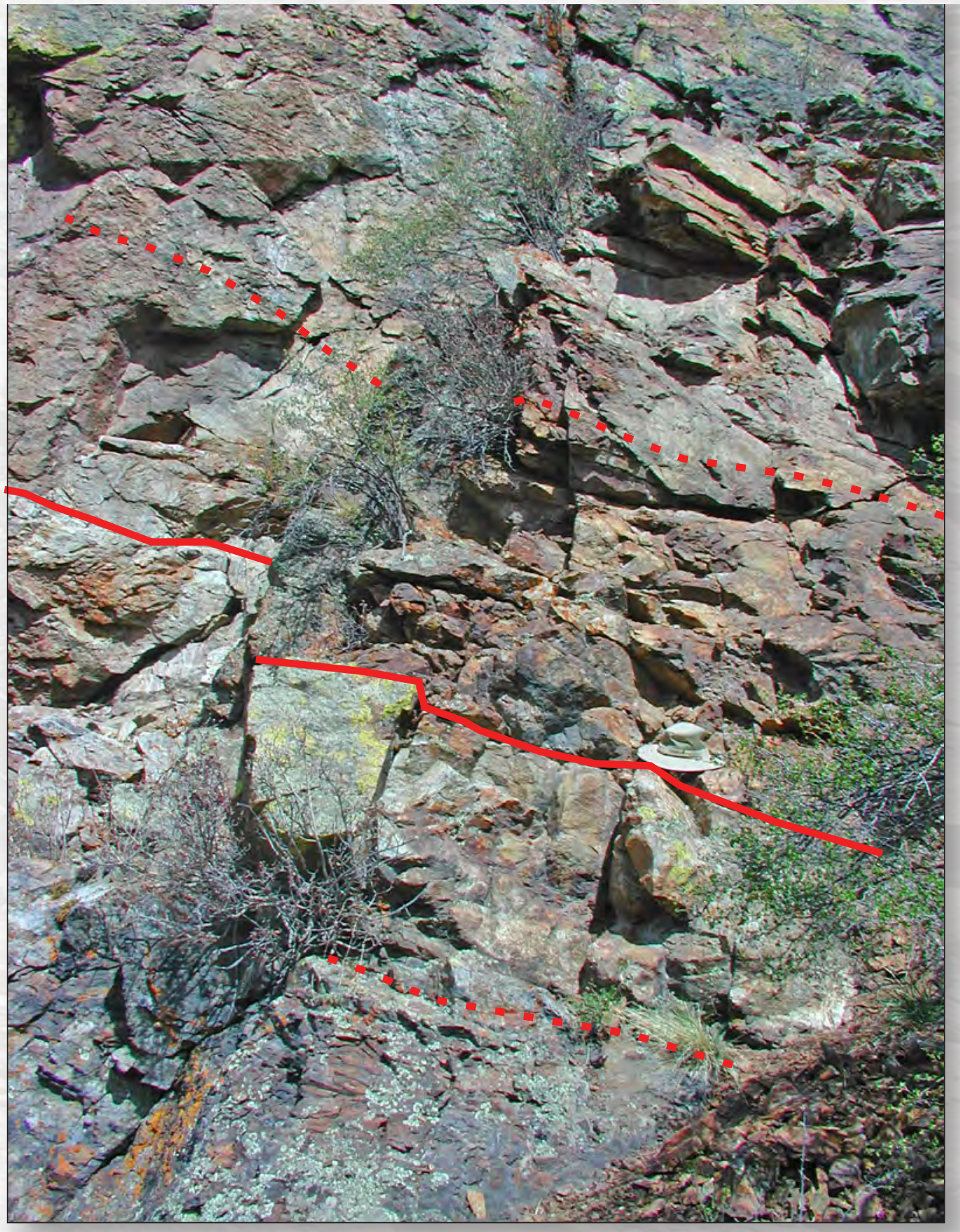

Figure 13. Structural zones of the Williams Range thrust fault near Keystone, exposed in a "window" through the thrust near the west end of the Montezuma stock. Heat from magma that formed the stock baked the Pierre Shale, which then transformed into a hard rock called hornfels. Hat near main fault shows scale. View is to the northwest.

\section{Migmatitic \\ biotite \\ gneiss}

Brecciated and oxidized gneiss

Main fault

Sheared and silicified

Pierre Shale

"Baked"

Pierre Shale

(hornfels) 
Figure 14. Dike emplaced 26-25 million years ago (late Oligocene) of hornblende latite porphyry forms Haystack Butte. View shows northwest end of dike, which is about 25 feet thick. View to the southeast. 


\section{Igneous Activity and the Laramide Orogeny}

The Laramide orogeny was also marked by voluminous intrusions of irregular stocks, sills, and dikes ranging from gabbro to granite (or basalt to rhyolite in finer-grained rocks), mostly in the southern part of the Blue River Basin. Some of these intrusive rocks may have breached the surface, forming volcanoes that have long since eroded.

The oldest of these rocks, such as sills and stocks of the Pando Porphyry (much more prominently exposed near Leadville, south of the Blue River valley), are about 72 million years old, which is about the time at which the Laramide orogeny began. The Pando Porphyry is a fine-grained granite with larger grains (called phenocrysts) of quartz. However, the youngest intrusive rocks, associated with the Climax granite porphyry intrusive complex near Fremont Pass (fig. 2), are about 24 million years old (late Oligocene); so intrusive activity continued after the close of the Laramide orogeny. The largest intrusive bodies, which have granitic compositions, intruded about 40 million years ago. They include the large granite porphyry stock at Swan Mountain south of Dillon (fig. 7), the stock just east of Boreas Pass, and the Montezuma stock (including numerous nearby dikes and small intrusive bodies) (fig. 7). At Green Mountain (fig. 2), just north of Green Mountain Reservoir, sills, dikes, and small stocks of fine-grained gray porphyry (called latite and trachyte porphyry) are about 31.5 million years old, although a prominent dike of similar composition north of Green Mountain at Haystack Butte (figs. 2 and 14) is about 25 million years old. 


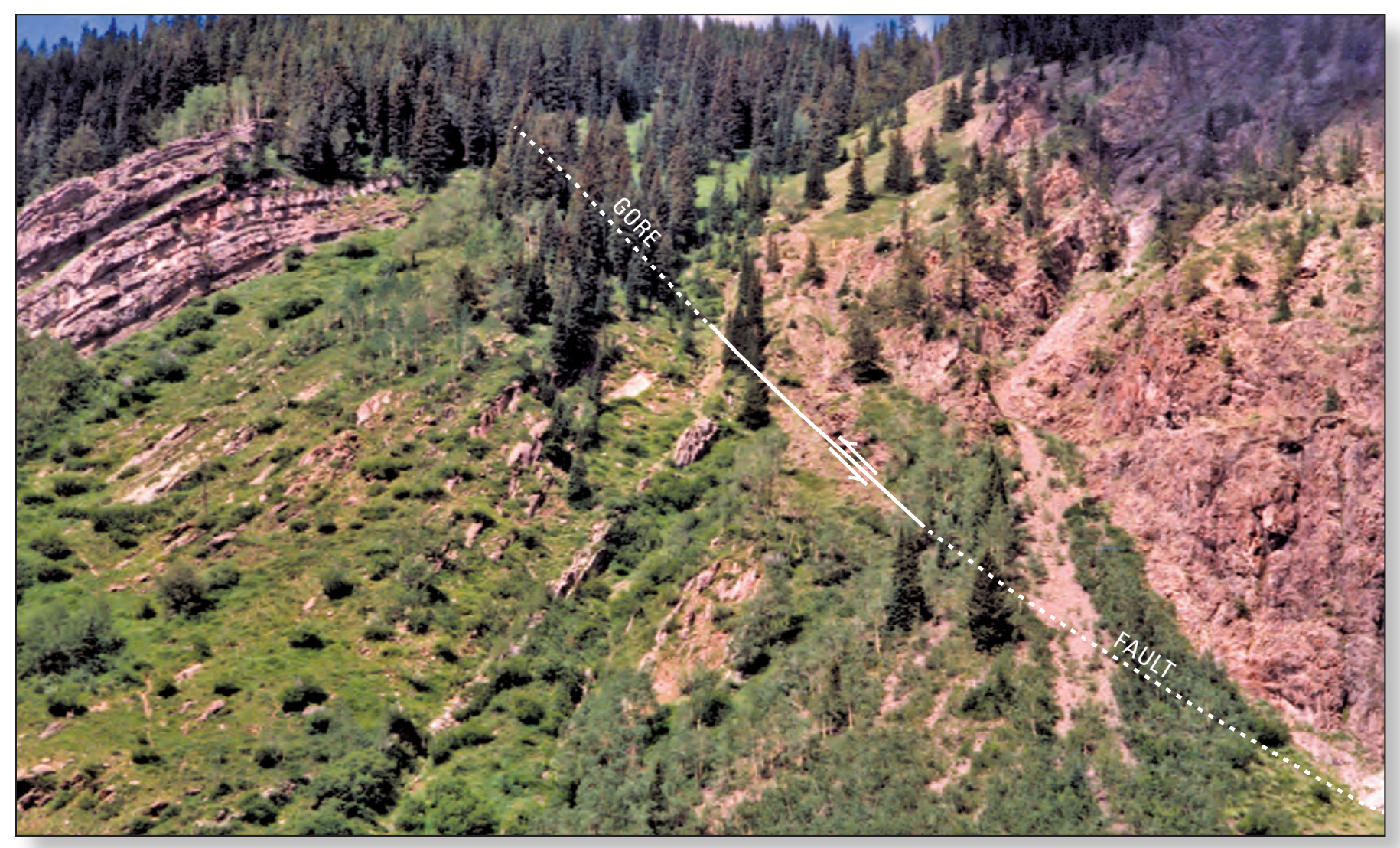

Figure 15. The Gore fault (white line; dotted where concealed by Quaternary deposits) near Vail. Steeply west-sloping beds of the Minturn Formation left of the fault are in contact with fractured Paleoproterozoic granite (Cross Creek Granite) on the right. Arrows show relative movement above and below the fault. View is west across Booth Creek.

\section{The Gore Fault Zone and Faults Cutting Proterozoic Rocks of the Gore Range}

Let us now turn our attention to the Gore Range and the enigmatic Gore fault zone that marks the west side of the Gore Range. Sorting out the history of movement along the Gore fault zone (figs. 7 and 10) is complicated because the zone was recurrently active at least as long ago as the late Paleozoic, and perhaps as long ago as the Neoproterozoic. Most movement along the Gore fault zone, however, took place during the Laramide orogeny; so most faults of the zone are thrust faults or reverse faults that formed during contraction of the Earth's crust. The Gore fault zone also contains some faults that moved during crustal extension after the Laramide orogeny, discussed in the next section. At the surface, beds of the Minturn Formation are nearly vertical or are overturned immediately southwest of the fault zone. A particularly well-exposed fault contact between steeply dipping Minturn Formation and fractured Paleoproterozoic granitic rock (Cross Creek Granite) can be seen near Booth Creek, just north of Vail (fig. 15). All lower Paleozoic rocks along and northeast of the fault zone were eroded during late Paleozoic uplift, except for thin remnants of Cambrian Sawatch Quartzite and Ordovician dolomite that are locally preserved in fault-bounded blocks.
The north-northwest-trending faults that cut the Proterozoic basement of the Gore Range have also had a very long history that may record at least four periods of movement, here listed from oldest to youngest:

1. Movement related to late Paleozoic uplift of the Ancestral Front Range;

2. Uplift related to the Laramide orogeny;

3. Strike-slip movement (both sides of the fault moved horizontally) related to a poorly understood mid-Tertiary interval of deformation; and

4. Crustal extension related to formation of the Rio Grande rift (discussed in the next section), which produced late Oligocene and younger normal faulting, crustal heating, and uplift parallel to and along the Blue River normal fault.

Another set of east-northeast-striking faults cuts the Proterozoic basement of the Gore Range and is probably related to differential uplift of the range during the Tertiary Period. A particularly large down-to-the-northwest fault system just north of Mt. Powell (fig. 2) separates the high, rugged terrane south of the fault from the lower and gentler topography of Elliott Ridge. 


\section{The Continent Pulled Apart- Development of the Northern Rio Grande Rift}

Following the Laramide orogeny, which persisted until the early Eocene (about 50 million years ago), a period of relative quiescence and erosion preceded a renewed episode of crustal unrest, beginning in the Oligocene, about 30 million years ago. Crustal extension and increased volcanism dominated the geologic events of the region during this time and formed north-trending grabens (down-dropped crustal blocks bounded by faults) of the Rio Grande rift (fig. 16). The rift extends southward from the Blue River valley, steps westward into the upper Arkansas River valley, extends southward into the river valley of the Rio Grande of southern Colorado and New Mexico, and continues into northern Mexico. Normal faults associated with formation of the Rio Grande rift also extend north into Wyoming, although the Blue River valley is the northernmost topographical expression of the rift.

Alkali basalt (which contains relatively high amounts of potassium and sodium as compared to other basalts) and andesite lava flows cap ridges west of Green Mountain Reservoir, particularly on and near Piney Ridge (fig. 2), where more than 25 flows are stacked. These rocks are part of a large, eroded volcanic field that extended from the Blue River westward at least to State Bridge along the Colorado River, about 18 miles southwest of Kremmling. These types of basalts are typical of those that erupted during periods of crustal extension and rifting. Ages of basalt flows near State Bridge were calculated from the decay of isotopes of potassium to argon. These ages are all between 24.0 and 22.5 million years old, similar to three ages of about 23.6 million years from andesite lava flows in the northern Blue River Basin near Otter Creek.

The graben underlying the Blue River valley is called a "half-graben" because only one major fault, the Blue River normal fault (figs. 7 and 10), bounds the graben on the west side; there is no large normal fault on the east side of the graben. As a result, bedrock strata beneath the valley floor generally tilt down to the west. Unlike other parts of the Rio Grande rift to the south, the Blue River half-graben is relatively narrow, and Tertiary basin-fill deposits that once filled the graben have been mostly eroded. Only a few hundred feet of basin-fill deposits (sandstone, gravel, and volcanic rocks) remain in several places, and those are mostly mantled by thick late Tertiary and Quaternary gravels and Quaternary glacial deposits. Elsewhere in the graben, Cretaceous rocks (mostly shale and sandstone of the Pierre Shale are exposed. The oldest dated volcanic rocks interbedded with the basin-fill sedimentary rocks are about 27 million years old (late Oligocene), which marks the approximate time of initial rifting. These dated rocks include ash-flow tuffs (fig. 17) which flowed into the early-formed valley as hot, incandescent clouds of ash from an exceptionally large caldera ("supervolcano") eruption or eruptions to the south in Colorado, possibly from the San Juan Mountains in southwestern Colorado. When these hot clouds of ash settled, they were hot enough to weld into a relatively hard rock.

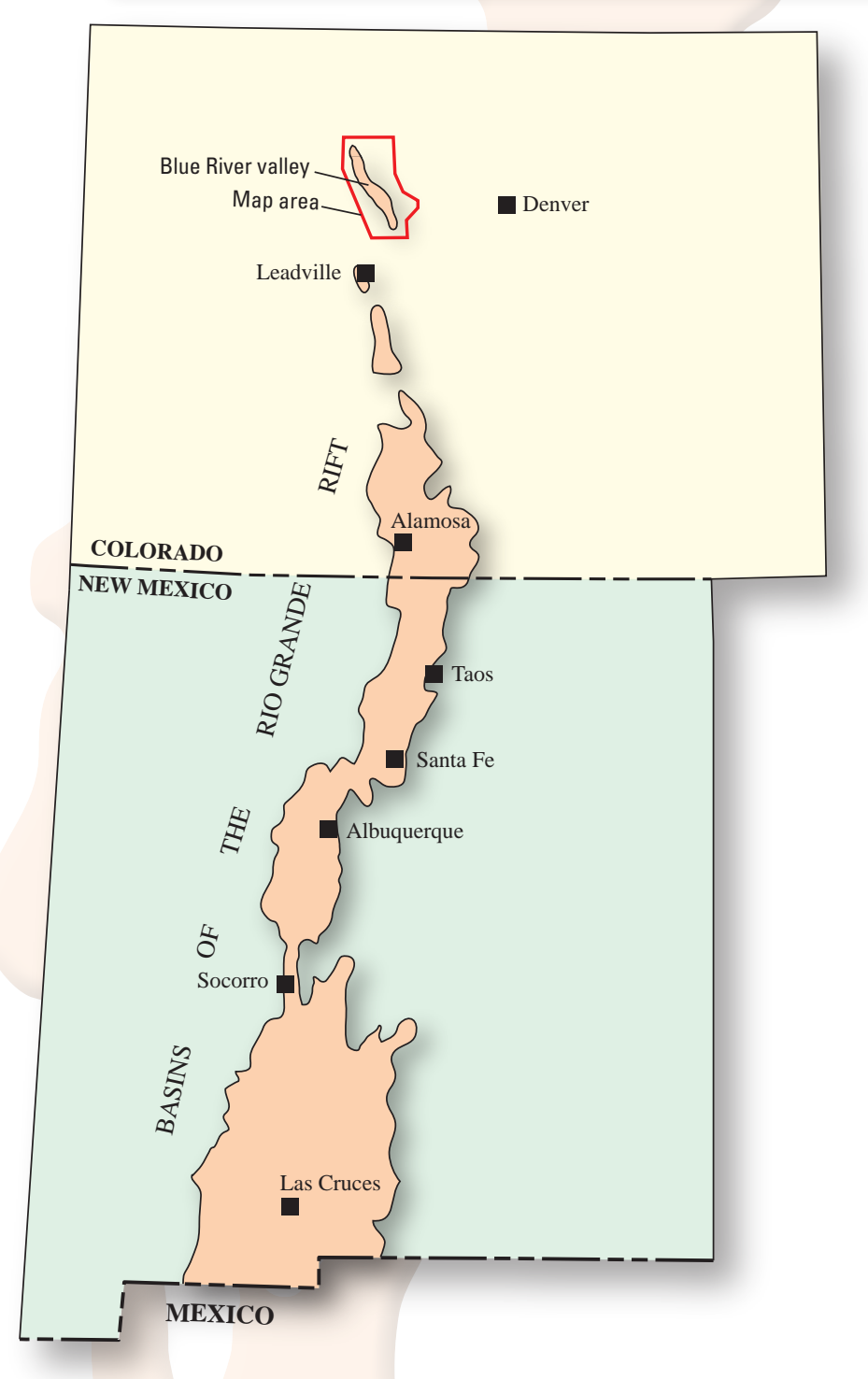

Figure 16. The Rio Grande rift. Tan areas represent basin-fill deposits that once filled rift valleys (grabens); associated faults are not shown. Basin-fill deposits of the Blue River valley have largely been eroded. 
Onformation Box 2.

\section{Dating Igneous Rocks by Using Radioactive Decay of Potassium to Argon}

How are these potassium-argon ages calculated? The method is similar to that used to measure the age of very old rocks in which isotopes of uranium decay to isotopes of lead in tiny zircon crystals (see information box 1. Dating Rocks by Using Zircon). The potassium-argon and argon-argon methods use the decay properties of a radioactive isotope of potassium $\left({ }^{40} \mathrm{~K}\right)$, which decays at a precisely known rate to various isotopes of argon. The relative amounts of each of these isotopes in an igneous rock can be measured by a mass spectrometer, which, in turn, can be used to calculate the age of an igneous rock since the time it cooled from a magma. The isotopes are generally measured in grains of the minerals sanidine, biotite, or hornblende.

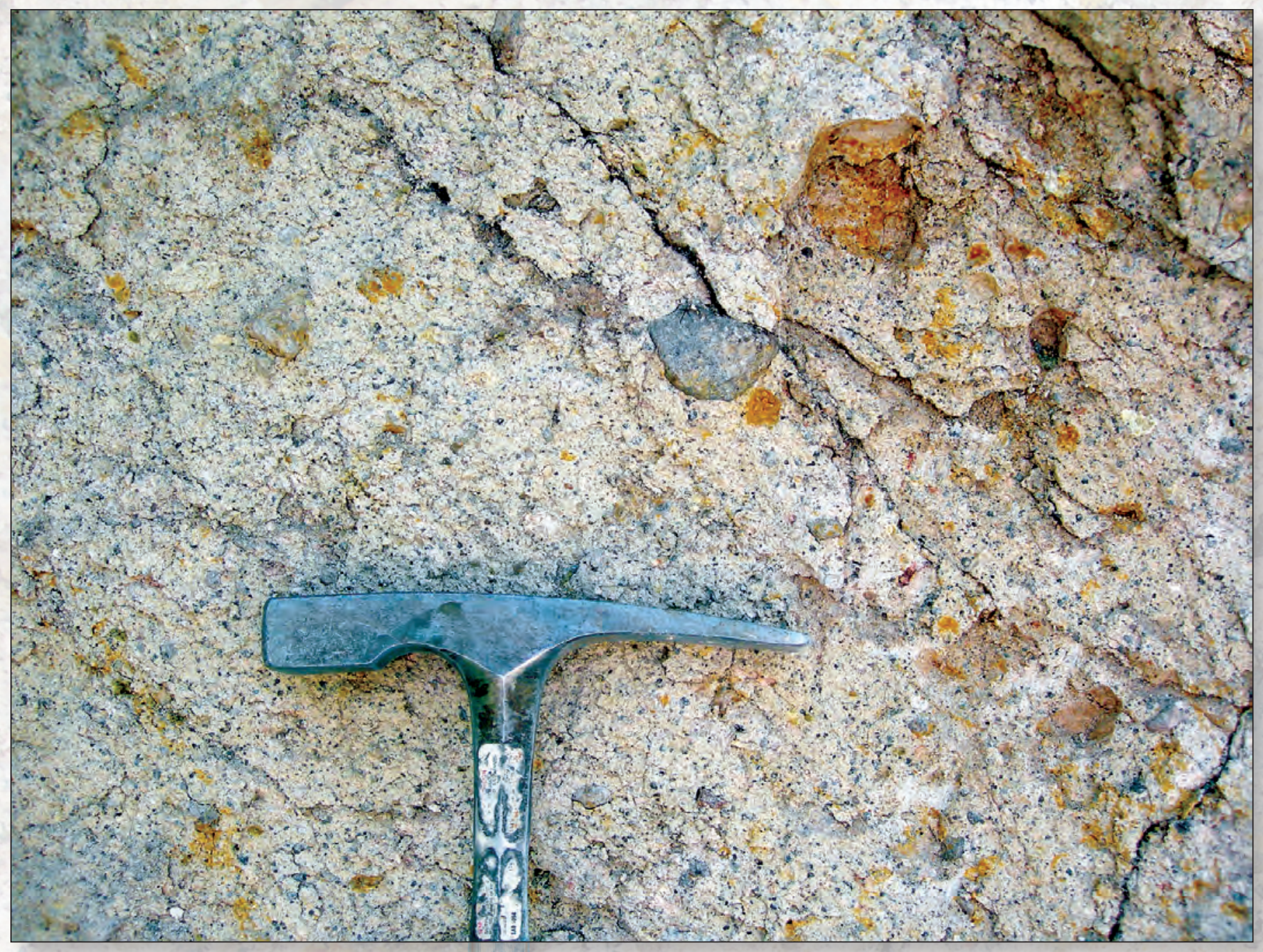

Figure 17. Outcrop of moderately welded upper Oligocene tuff near South Brush Creek. About 60 percent of the rock is very fine grained matrix; the balance is made up of crystals of quartz, biotite, plagioclase, and sanidine (high-temperature potassium feldspar), and small fragments of obsidian (volcanic glass), light-colored volcanic rocks, and Proterozoic gneiss. This tuff is about 27 million years old, probably came from a volcanic eruption many miles to the south, and is one of the oldest rocks infilling the very early valley of the ancestral Blue River. Hammer head 8 inches long. 


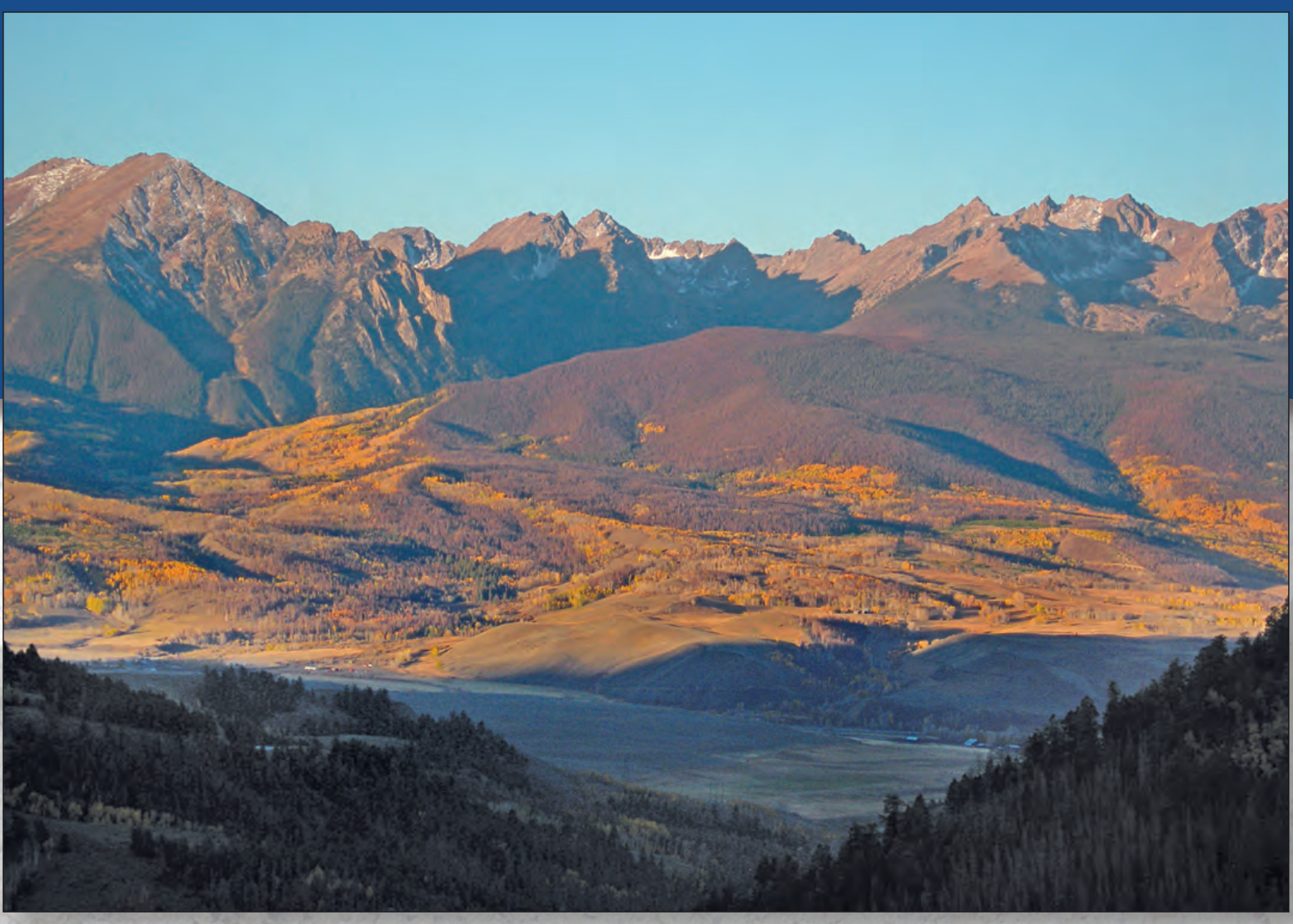

Figure 18. Early morning view of the Gore Range from Ute Pass. View is west across the Blue River valley toward the valley of Slate Creek. The Blue River normal fault lies along the eastern base of the range, behind the large, rounded, forested hill in foreground. This hill is underlain mostly by bouldery material (till) that was deposited by glacial processes. Rusty-red color of lodgepole-pine forest due to widespread infestation by pine-bark beetles.

The Blue River normal fault along the east side of the Gore Range offsets the top of the basement rocks vertically by at least 3,600 feet (fig. 18). In addition, many of the Mesozoic rocks of the Blue River valley, dominated by the more than 5,000-feet-thick Pierre Shale, are cut by several normal faults that are all down on their east sides. The Pierre Shale was originally more than 8,000 feet thick in the area, but the upper 3,000 feet have been removed by erosion. The consistent down-to-the-east displacement of faults in the Blue River valley suggests that they may curve downward into a nearly flat plane of weakness, possibly the reactivated Laramide-age Gore fault, which also curves down to the east (fig. 19). Movement along the Blue River normal fault may be as young as Holocene, but the timing of youngest movement, undoubtedly accompanied by intense earthquake activity, is controversial (refer to information box 3, Earthquakes and Age of Recent Faulting).

The controversy about the age of faulting continues. For example, low (less than about 6 feet high), subtle fault scarps west of Interstate Highway 70, just northwest of Frisco, cut gravel deposits of Pliocene(?) to middle Pleistocene age.
Subtle scarp-like features that cut glacial till as young as late Pleistocene (deposited during the Pinedale glaciation) have also been identified along the Blue River normal fault northwest of Frisco and Silverthorne, suggesting possible Holocene movement, but further study is needed to verify the origin of these features.

The flanks of the Blue River valley, along the Gore Range and western Front Range, uplifted faster than areas more distant from the valley. We know this from studies of apatite fission-track ages (see information box 4. What Apatite Fission Tracks Tell Us about Uplift and Cooling History). Oligocene to late Miocene fission-track ages (as young as 6 million years old) from rocks adjacent to the graben in the Gore Range and western Front Range are considerably younger (by several tens of millions of years) than fission-track ages recorded farther from the graben. This relationship indicates that uplift along the flanks of the Blue River graben is relatively young as compared with uplift in areas more distant from the graben. 


\section{Earthquakes and Age of Recent Faulting}

Although Colorado is not generally regarded as an area with substantial earthquake risk, large earthquakes have occurred in the Front Range region. An earthquake of inferred Richter magnitude 6.5 caused considerable damage in the northern Front Range in 1882, and scattered earthquakes of smaller magnitude periodically shake the region. Because the Blue River valley lies near the northern terminus of the Rio Grande rift-an active zone of crustal extension, elevated heat flow, and late Tertiary uplift along its flanks - one might expect a relatively high seismic hazard potential.

Paradoxically, the faults in the Blue River valley have not been historically active, and this part of the Rio Grande rift is seismically quiet lalthough the timing of youngest movement along normal faults in the valley, such as the Blue River normal fault, is controversial). The well-known Colorado geologist Ogden Tweto suggested that the prominent scarp that defines the Blue River normal fault along the east side of the Gore Range indicated Holocene movement. One indication of Holocene, and perhaps currently active, movement are "gouge boils." These features are mounds as high as $\mathbf{3 6}$ feet found in treeless areas above the trace of the Blue River normal fault. They are composed of fine-grained "fault gouge," interpreted by Tweto as material that extruded upward along the fault zone and shouldered aside bouldery material. Other geologists have challenged Tweto's assessment of Holocene faulting and have, in fact, suggested that movement on the Blue River normal fault was probably no younger than the middle of the Pleistocene Epoch.

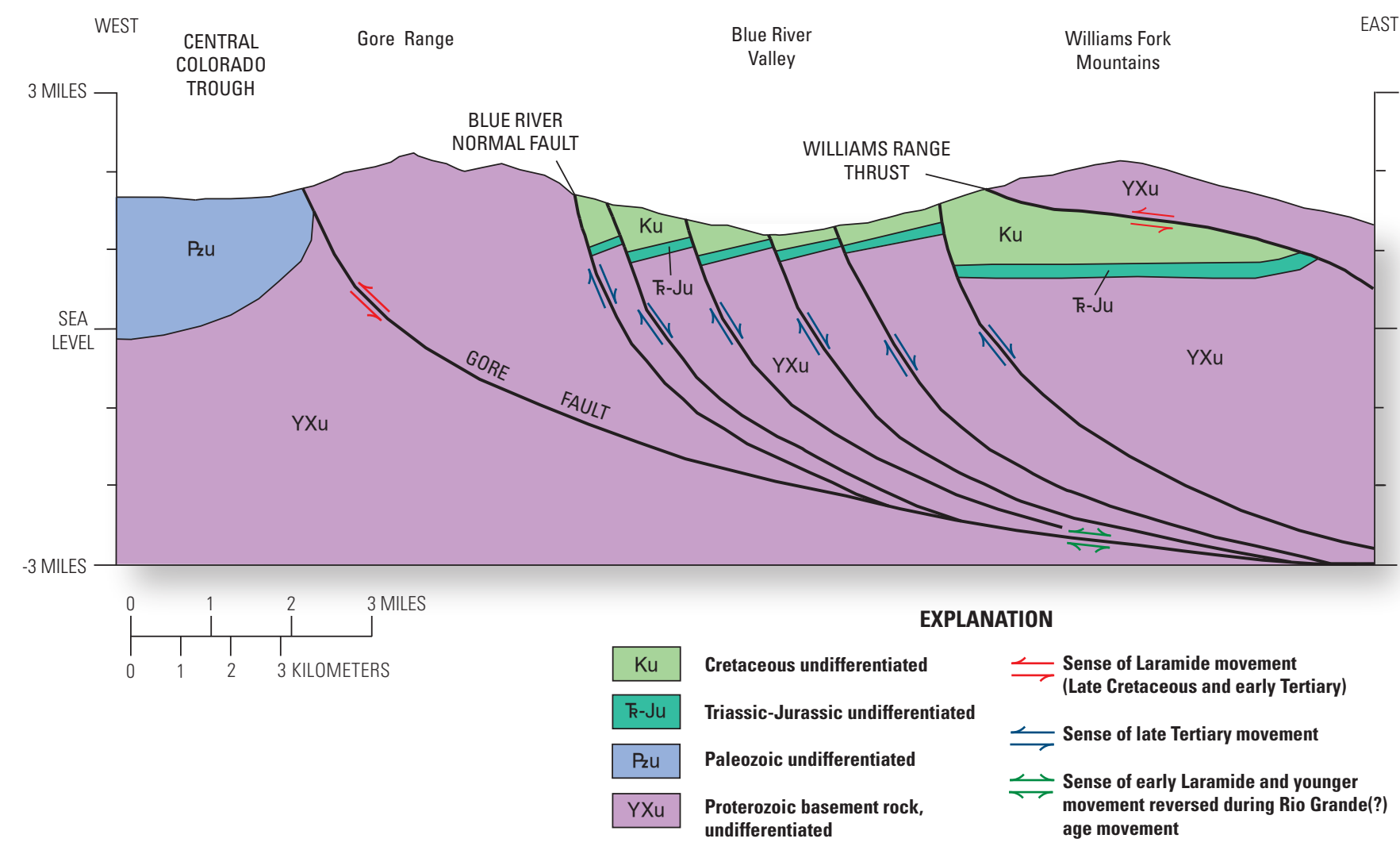

Figure 19. Cartoon east-west cross section across the Blue River valley, approximately between lines of section $A-A^{\prime}$ and $B-B^{\prime}$, showing proposed relationship of down-to-the-east normal faults, including the Blue River normal fault, which suggests that these Rio Grande-age (Oligocene or younger) faults merge into a detachment surface at depth, possibly the older (Laramide-age) Gore fault (relationship suggested by Kellogg, 1999). 
Onformation Box 4.

\section{What Apatite Fission Tracks Tell Us about Uplift and Cooling History}

Apatite (calcium phosphate, $\mathrm{CaPO}_{4}$ ), is found as scattered tiny crystals in virtually every rock. Fission tracks in apatite crystals are produced by high-speed particles released by the spontaneous decay of ${ }^{238} \mathrm{U}$ (which occurs in very small amounts in apatite). The tracks are retained generally below about $100{ }^{\circ} \mathrm{C}$ (they anneal, or disappear, above this temperature). The density of these fission tracks, measured on a polished surface of a rock under a microscope, is proportional to the time since the rock cooled below about $100^{\circ} \mathrm{C}$; so they can be used to calculate the time at which a rock cooled through this temperature. A rock at depth is hot owing to the geothermal gradient in the Earth's crust, and it cools as an area uplifts and overlying rock is removed by erosion. Ages calculated from fission tracks, then, provide a good way to determine both the cooling and uplift history of the rocks

\section{The Upper Oligocene to Upper Miocene Troublesome Formation- Was It All That Troubling?}

Northeast of the Blue River half-graben lies a separate downwarp, the Middle Park Basin (fig. 7). This basin underlies a generally north-northwest-trending, sagebrush- and grasscovered broad valley of relatively low topographic relief. The basin is bounded in places by normal faults, so it is a broad rift basin that formed at approximately the same time as other basins of the Rio Grande rift. The Middle Park Basin is filled with several hundred feet of brown to yellowish-tan and relatively soft rocks of the Troublesome Formation (fig. 7, part of unit Tb) — siltstone, sandstone, conglomerate, and minor volcanic ash deposits. The sediments composing these rocks were deposited during late Oligocene to late Miocene time (about 28 to 11 million years ago) in part by streams in and near the headwaters of the ancestral Colorado River. Volcanic ash deposited from distant volcanic eruptions can be used to date these deposits. The soft, easily eroded Troublesome Formation locally forms a sparsely vegetated, badlands landscape in Middle Park. The rocks of the formation are not really troublesome to understand; the formation is named after Troublesome Creek near Kremmling, whose wet or muddy siltstone was probably difficult for early wheeled vehicles to cross.

\section{What Happened to All the Sediment That Once Filled the Blue River Valley?}

The Blue River valley undoubtedly contained a very thick sequence of sedimentary rocks by the beginning of the Pliocene Epoch (about 5 million years ago). Because most of these rocks have been removed by erosion, it is not clear how thick this sequence was. These rocks were equivalent to those of the Troublesome Formation in the Middle Park Basin, but they also included younger sediment that was shed off the Front Range and into flanking valleys, including the Blue River valley, during a poorly understood period of late Miocene and early Pliocene erosion. The thick Miocene to perhaps early Pliocene Ogallala Formation, which composes a large aquifer of the eastern plains of Colorado and adjacent states, was also deposited at this time from the debris eroded from the Front Range and adjacent ranges north and south of the Front Range. Geologists continue to debate whether the erosion was caused by renewed uplift, causing streams to incise into the mountains owing to steeper gradients, or whether it was caused by climate change, in which increased precipitation gave streams additional erosive power. Both these factors may have been at work.

Deposition ceased by about 5 million years ago. Rivers began eroding the thick sequence of upper Tertiary sedimentary rock and, eventually, cut into the underlying older rocks. The Blue River was no exception. It eroded virtually all the Tertiary sedimentary rocks in the Blue River valley, so that now only a few vestiges of these rocks remain. Much of the underlying Cretaceous rock has also been eroded and washed into the Colorado River, which carried most of the sediment into the Gulf of California. 


\section{The Ice Ages}

Glacial erosion and deposition, primarily during the Pleistocene Epoch, were the last major events to modify the high mountain landscape of Summit County. Glaciers slowly transformed V-shaped river valleys into straighter U-shaped valleys, and they deposited large masses of glacially transported rock debris, called till, when the ice melted. The straight or curved ridges composed of till are called moraines. Large streams issuing from the melting ice redeposited some till in broad plains as glacial outwash. These periods of glacial erosion and deposition resulted from periodic major climate changes which drove several glacial-interglacial cycles. Global climatic cooling began about 2.6 million years ago at the beginning of the Quaternary Period and intensified after about 900 thousand years ago, although it was interrupted periodically by limited periods of warming. Time will tell whether the present period of global warming marks an abrupt end to this cyclic trend.

During each of these glacial events, the landscape looked considerably different from how it looks now. Long rivers of ice partly filled the upper parts of high mountain valleys, and perennial snowfields probably mantled some of the adjacent high terrain. Glaciers in the Rocky Mountains advanced and retreated at least 12 times during the Pleistocene, but because each advance tended to overrun or conceal evidence of previous advances or glaciations, only the last two major glaciations left widespread evidence of their extent and imprint on the modern landscape. The Pinedale glaciation, the last major glacial event, took place between about 30 and 12 thousand years ago; the Bull Lake glaciation, the next older glacial event, was active between about 190 and 120 thousand years ago. Both were named for glacial deposits on the western and eastern flanks of the Wind River Range in Wyoming, respectively. The approximate extent of glaciers of Pinedale and Bull Lake age in the Blue River region is shown in figure 20.
Till and locally minor amounts of glacial outwash of the Pinedale glaciation form well-preserved, hummocky moraines that are widespread in larger valleys along the east flank of the Gore Range and in the Blue River valley and its major tributaries. Moraines of the Bull Lake glaciation are much more smoothed and rounded by erosion than those of Pinedale age. Bull Lake till is much more weathered, so that boulders are more disintegrated and the upper 6 to 9 feet of the till is oxidized (light-yellow or brown color) and turned partially to clay (fig. 21). Pinedale-age till, in comparison, is much fresher and commonly is grayer, with little soil or clay development (fig. 22). Typically, till lacks visible layering and contains particles ranging in size from silt to boulders.

The youngest glacial deposits in cirques of the Gore Range form sharp-crested moraines; they may correlate with those in the Front Range that are about 12 thousand years old and younger. These tills lie above present tree line near cirque headwalls, typically above an elevation of 11,000 feet. They were deposited during minor glacial advances after the Pinedale glaciation. These deposits are within areas that were covered by glaciers during the Pinedale glaciation (fig. 20).

Small glaciers still exist in some of the highest cirques of the Gore and Tenmile Ranges. These glaciers are concealed by a layer of boulders and finer debris, which effectively insulates the underlying ice, which generally is not visible. Consequently, these glaciers are called "rock glaciers" (fig. 23). Active rock glaciers, those that have a substantial ice core, move slowly down valley and have a steep, bouldery front face. Inactive rock glaciers, in which the ice core has mostly or completely melted, have a more gentle front face, and dense lichens cover most exposed rock surfaces. 


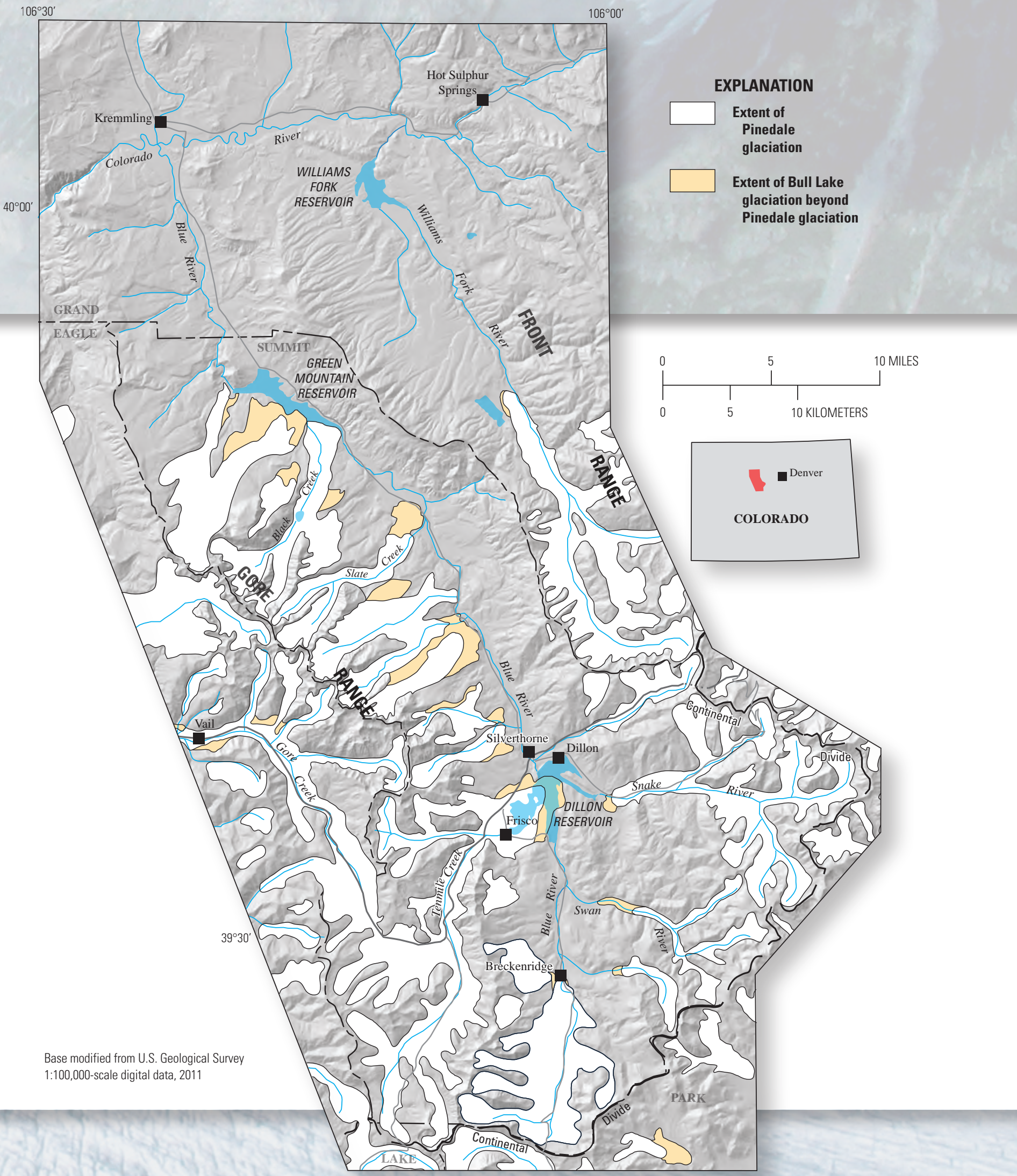

Figure 20. Blue River valley region showing extent of Pleistocene glaciers. Bull Lake glaciers (active about 190 to 120 thousand years ago) extend in most places a mile or two beyond the extent of Pinedale glaciers (active about 30 to 12 thousand years ago), although extent of Bull Lake glaciers in some valleys is not known. In the southeast part of the map, county boundaries follow the Continental Divide. 


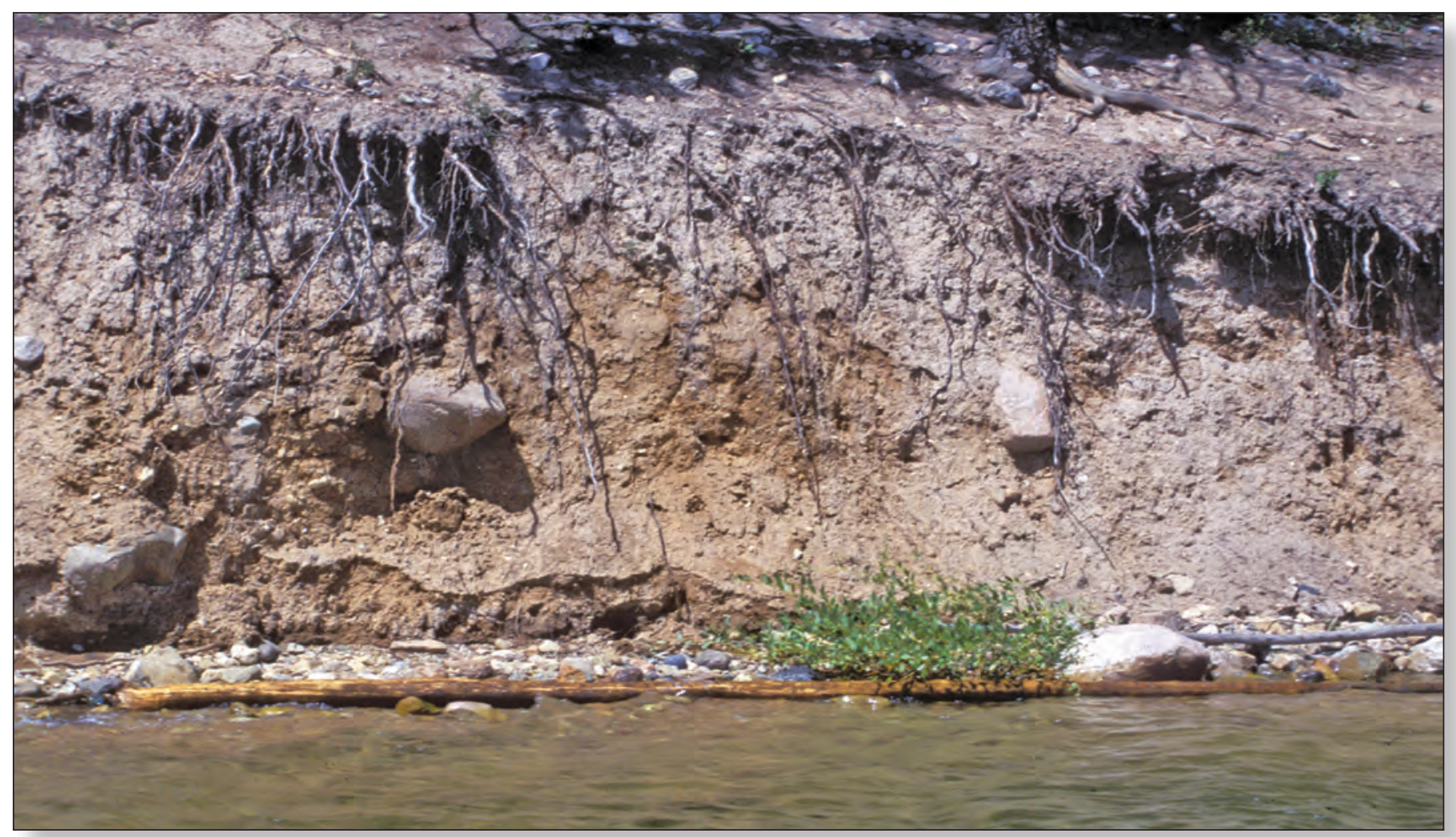

Figure 21. Unconsolidated till of Bull Lake glaciation in a 10-foot-high, wave-cut exposure along Dillon Reservoir, characterized by strong oxidation (brown color) in the lower part.

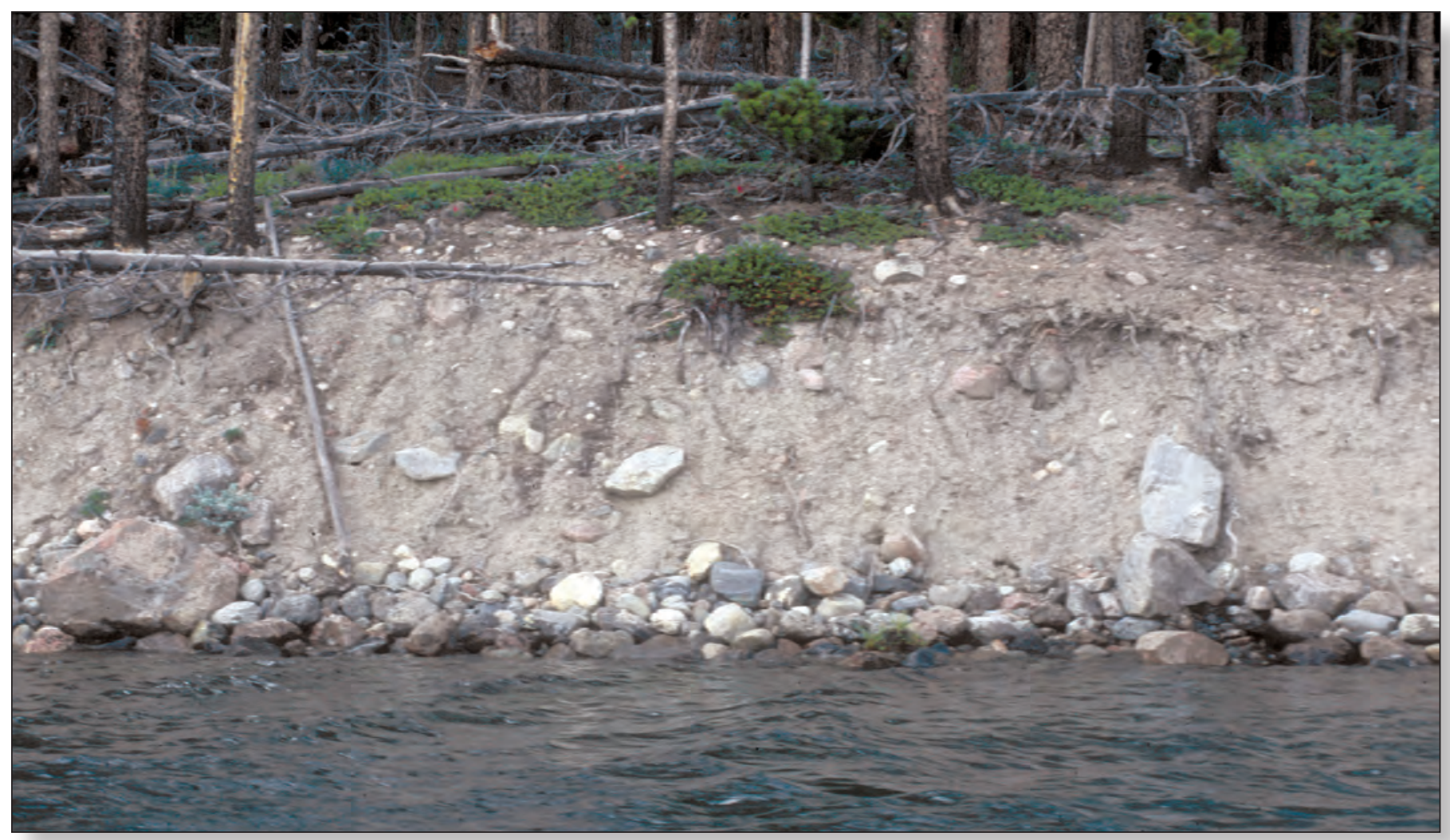

Figure 22. Unconsolidated till of Pinedale glaciation in a 6-foot-high, wave-cut exposure along shore of Dillon Reservoir. Soil is minimally developed and the till's general gray color indicates that the material is only slightly oxidized. 
Here are a few particular facts regarding Bull Lake and Pinedale glaciers that occupied the upper Blue River valley and its tributaries (fig. 20):

- The longest glacier in the Blue River drainage system, determined by the extent of glacial till, flowed down the valley of Tenmile Creek as far north as the dam at Dillon Reservoir. It was 18 miles long during the Bull Lake glaciation and only one mile shorter during the Pinedale glaciation; extensive glacial outwash and till deposited by the Pinedale glacier underlie the town of Frisco.

- The glacier that occupied the upper Blue River valley south of Breckenridge was about 8 miles long; terminal moraines formed during Bull Lake and Pinedale glaciations are just south of Breckenridge.

- The glacier in the Snake River valley was 11 miles long.

- The Williams Fork valley glacier was 16 miles long during the Bull Lake glaciation and was only 0.3 miles shorter during the Pinedale glaciation.

- Glaciers flowing out of the eastern part of the Gore Range were as long as 10.5 miles, as in the valley of Slate Creek.

- The glacier that occupied the valley of Gore Creek on the west side of the Gore Range was about 15 miles long during the Bull Lake glaciation.

- The lowest elevation reached by any glacier in the Blue River drainage system (about 8,250 feet), was at the terminus of the 9-mile-long glacier in the valley of Black Creek, now beneath the level of Green Mountain Reservoir.

The oldest pre-Bull Lake glacial deposits, deposited before 900 thousand years ago (early Pleistocene), are now mostly or completely buried by younger glacial deposits. Cold (glacial) and warm (interglacial) climatic cycles before 900 thousand years ago produced smaller global ice volume and were of much shorter duration than those after 900 thousand years ago.

Exposures of old, coarse, unstratified, deeply weathered, gravelly deposits that resemble till have been identified in several places. These gravels typically lack morainal form and are preserved a short distance down-valley from exposures of Pinedale or Bull Lake till. However, it is not always obvious if some deposits that resemble till are, in fact, till of pre-Bull Lake age. To be cautious, such deposits are called "diamictons," which implies that the genetic origin is unknown. Such diamictons are exposed at Mesa Cortina (fig. 24) and Gold Run; they may be large debris-flow deposits (flowed as bouldery mud) or alluvium rather than glacial till. These gravels are particularly interesting not only for the enormous size of the boulders (some are at least 25 feet long), but also for their gold content. These deposits were locally mined for placer gold, mostly in the 1860 s and $1870 \mathrm{~s}$.
Progressively older glacial deposits (or diamictons, deposits that resemble till but are of uncertain origin) on the east side of the Gore Range contain progressively higher percentages of Dakota Sandstone clasts. This relationship suggests that Dakota Sandstone bedrock was much more extensively exposed during the early Pleistocene and was increasingly covered by the debris of succeeding glacial episodes.

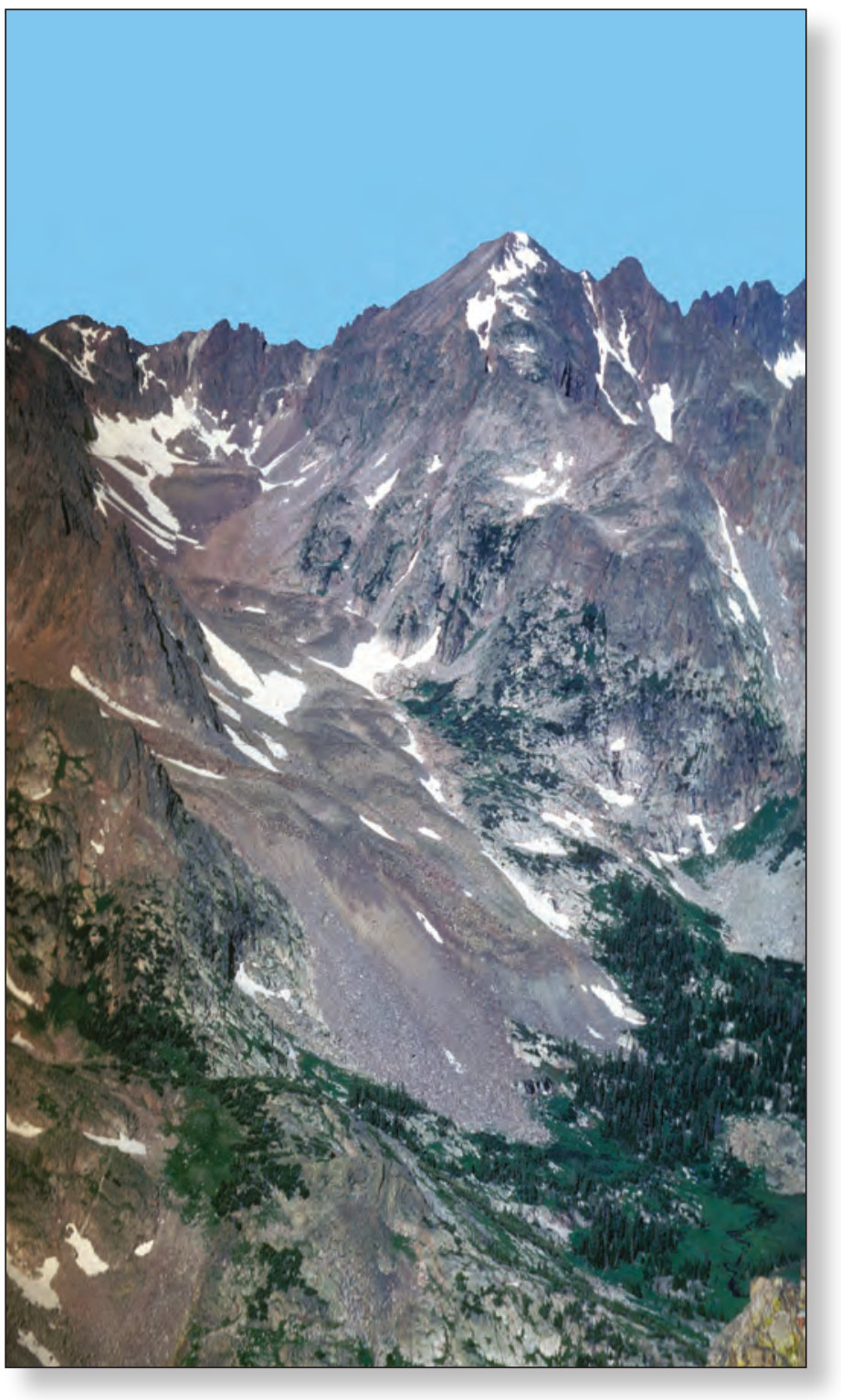

Figure 23. View, facing west, of the head of South Rock Creek in the Gore Range showing a large, active rock glacier. Although no ice is showing, the hummocky piles of rocks are likely cored by ice which is slowly moving down the valley. We know it is active because the steep front of the rock glacier is unstable and at the angle of repose; rocks tumble down the steep front almost daily. The front of the upper part of the rock glacier is particularly high and steep. 
Streams draining from glaciers produced broad, gravelly

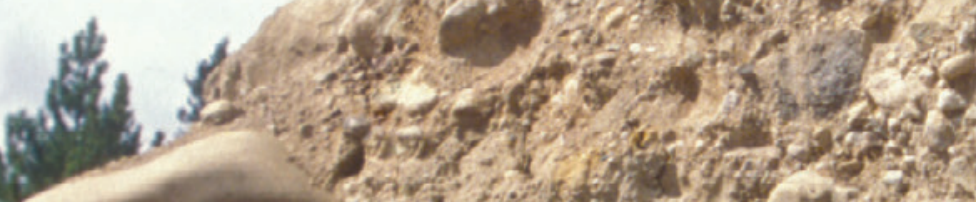

glacial outwash deposits, such as those underlying Frisco.

Particularly during deglaciation - times of substantially

greater stream flow and sedimentation - debris embedded

glacial ice was released and inundated downstream areas.

Temperatures during glacial episodes were certainly much

colder than they are now. In many periglacial environments,

nonglaciated areas such as along ridges beyond the limit of

glacial ice, vigorous freeze-thaw action and increased

precipitation would have promoted slope instability and

intensified mass movement in the Front and Gore Ranges

fields, block streams or stripes, and patterned ground.

Patterned ground refers to the polygonal shapes outlined by

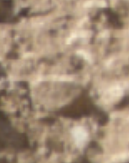

rocks that were forced to the surface and moved laterally during long episodes of freeze-thaw action.
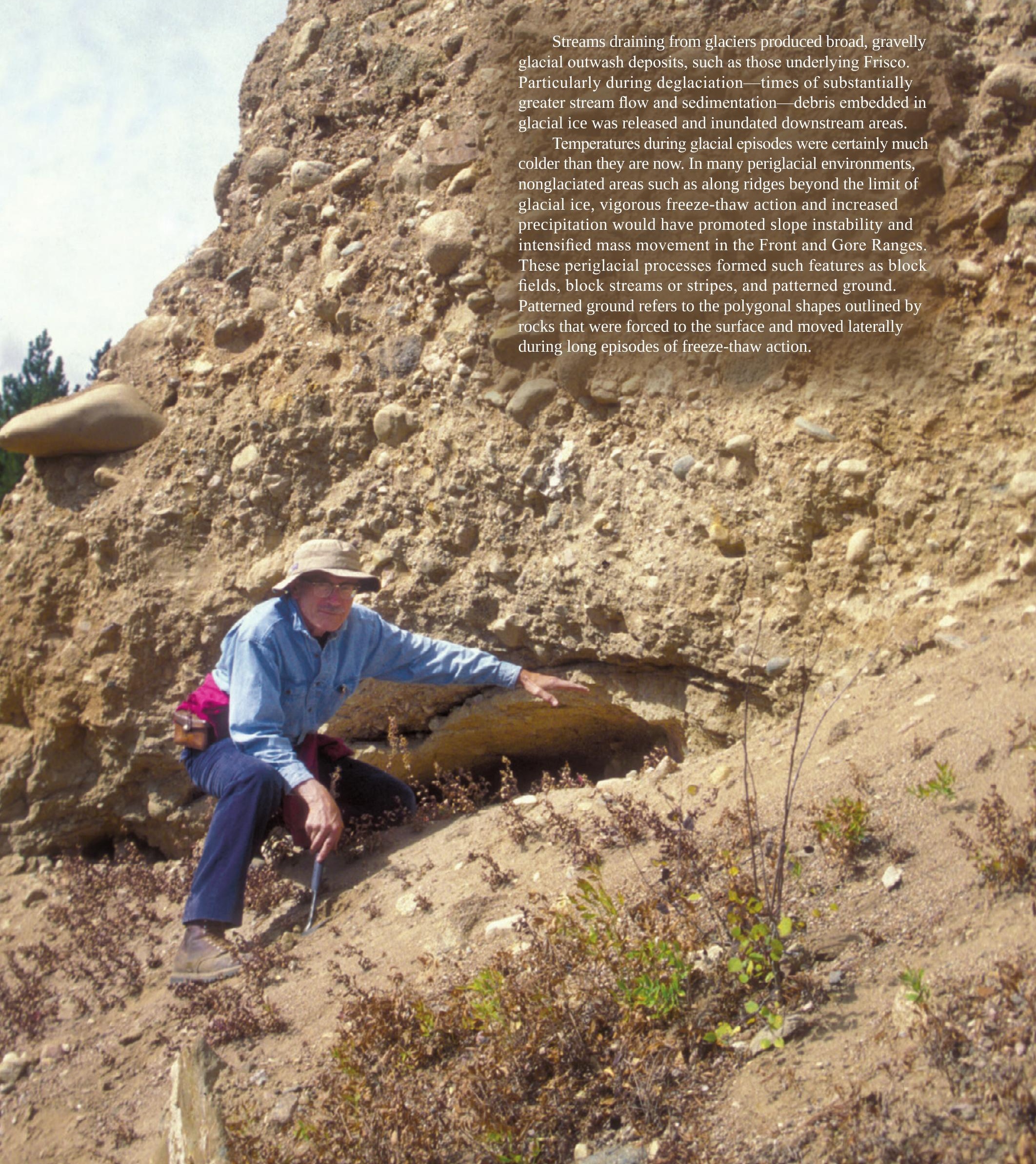


\section{Landslides and Spreading Mountains}

\section{Landslides}

Landslide deposits of varying sizes are a common feature along slopes of the Blue River valley. Most large landslides probably formed or were reactivated under periglacial conditions during the Pleistocene, although some of these slides were recurrently mobilized during the Holocene Epoch (the most recent 12,000 years or so). Some large landslide deposits in glaciated valleys along the east side of the Gore Range formed after glaciers retreated and glacial ice no longer provided lateral support to weakly consolidated material on steep, unstable slopes. A particularly large, old, and eroded landslide complex (fig. 7, unit QTI), involving only Proterozoic gneiss and granitic rocks, underlies the west slope of the Williams Fork Mountains (which form the western ridge of the more extensive Front Range). This deposit owes its origin largely to the highly fractured and weak bedrock underlying the ridge.

Conditions that contribute to landslides commonly include the following: (1) oversteepening of slopes by fluvial or glacial erosion at the base of slopes, or human undercutting of slopes (or both); (2) bedding oriented approximately parallel to slope; (3) deforestation by logging, mining, other human activity, or fires; (4) high water content in consolidated rock units or unconsolidated deposits (by intense or prolonged rainfall, or rapid or protracted snowmelt); and (5) vertical contrast in density or plasticity of geologic materials.

In the high country of the Gore Range, cliffs in Proterozoic rocks frequently produce rockfalls, especially in the spring when water from daytime melting of snow freezes and expands at night in cracks in rocks. Repeated freeze-thaw cycles tend to dislodge unstable rocks from cliffs. Talus deposits are the products of rockfall from high, steep, rocky outcrops.

Figure 24 (facing page). Gravel at Mesa Cortina, showing crude stratification and strong oxidation. The deposit is deeply weathered and may be as old as Pliocene. It is interpreted either as a set of large debris flows or alluvium rather than glacial till. The extent of these deposits beneath younger Quaternary deposits is unknown, as is the thickness. The face was exposed by late nineteenth century hydraulic mining for placer gold. Outcrop about 1,000 feet northwest of I-70, west of Silverthorne.

\section{What Are Sackungen and How Do They Form?}

The crest of the Williams Fork Mountains is relatively smooth and rounded, and it maintains a nearly constant altitude of about 12,000 feet. The underlying Proterozoic bedrock is densely fractured and relatively weak, a condition that has induced gravitational spreading of the entire range, somewhat like a large pile of bread dough. Peculiar features produced by this process are called "sackungen." Sackungen is a German word (singular form is sackung) for deep fractures with uphill-facing scarps that are induced by the gravitational spreading and are common along and near the crest of the range (fig. 25). The subdued topography of the Williams Fork Mountains is in stark contrast to that along the rugged crest of the Gore Range (fig. 18), where Proterozoic rocks underlying the range are relatively unfractured and strong, although sackungen do occur in several strongly fractured local areas near the Blue River normal fault.

Laramide-age movement along the Williams Range thrust fault probably is responsible for the dense fracturing of the rocks underlying the Williams Fork Mountains, which weakened the entire range. As erosion deepened the bounding valleys, these highly fractured mountains became gravitationally unstable and spread sideways slightly, forming cracks or sackungen (fig. 26). The gravitational instability also caused widespread landslides on the west side of the Williams Fork Mountains (fig. 7, unit QT1). These enormous landslide deposits are composed almost entirely of fragments and blocks of Proterozoic rock as long as about 50 feet derived from the strongly fractured upper plate of the Williams Range thrust fault (that is, rocks above the thrust plane). The landslide deposits moved downslope and concealed most of the trace of the thrust fault and much of the Cretaceous shale and sandstone (mostly Pierre Shale) on the west side of the range. Most of this landslide complex is deeply eroded and no longer retains a hummocky landslide morphology, suggesting that at least some of the landslides may be as old as Pliocene.

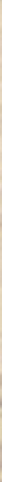




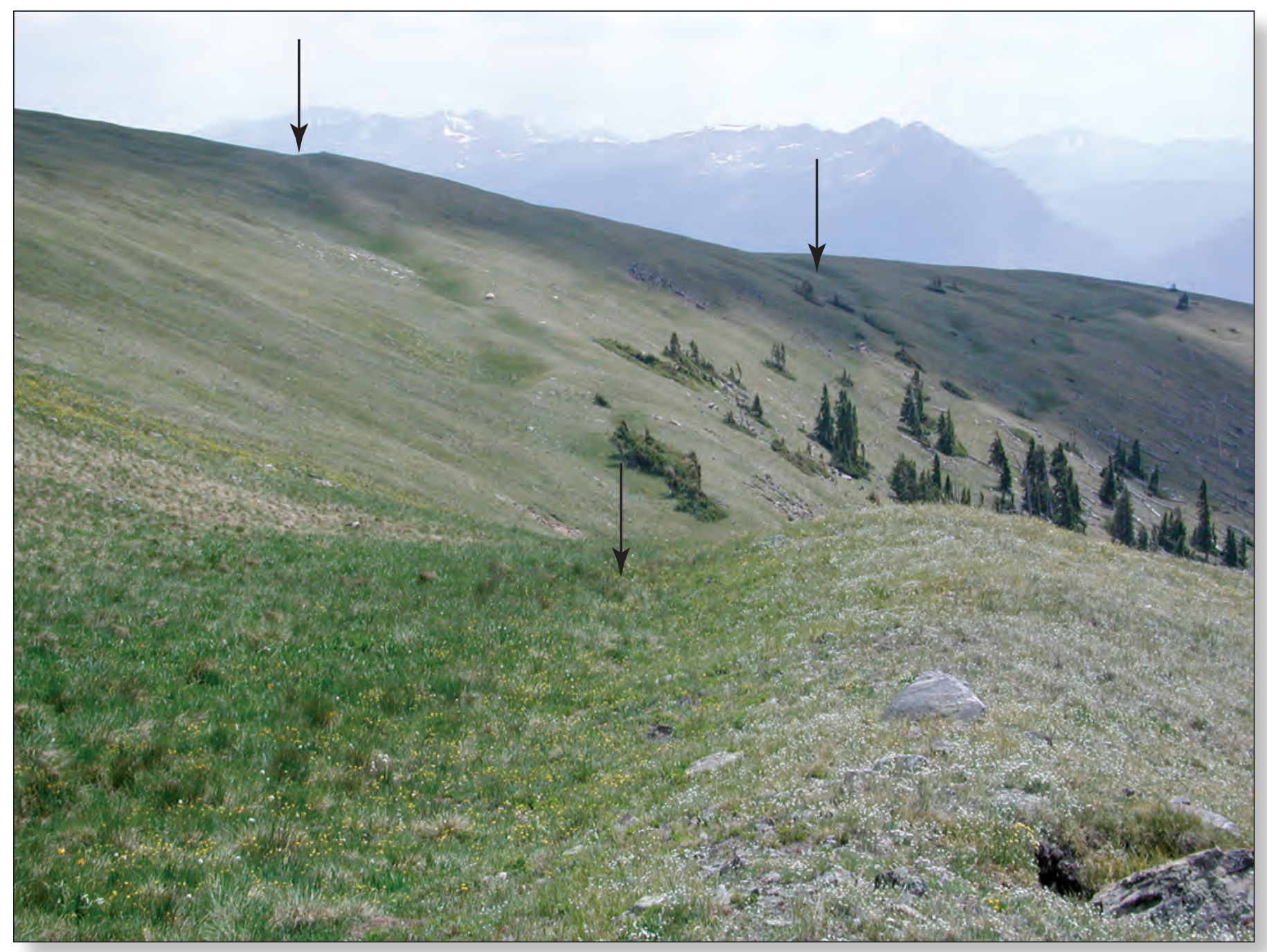

Figure 25. View to the south of sackungen (three of which are marked by arrows) near crest of southern Williams Fork Mountains. The sackungen, or deep-seated extension fractures, are marked by uphill-facing scarps caused by gravitational spreading of the entire ridge. Tenmile Range in background.

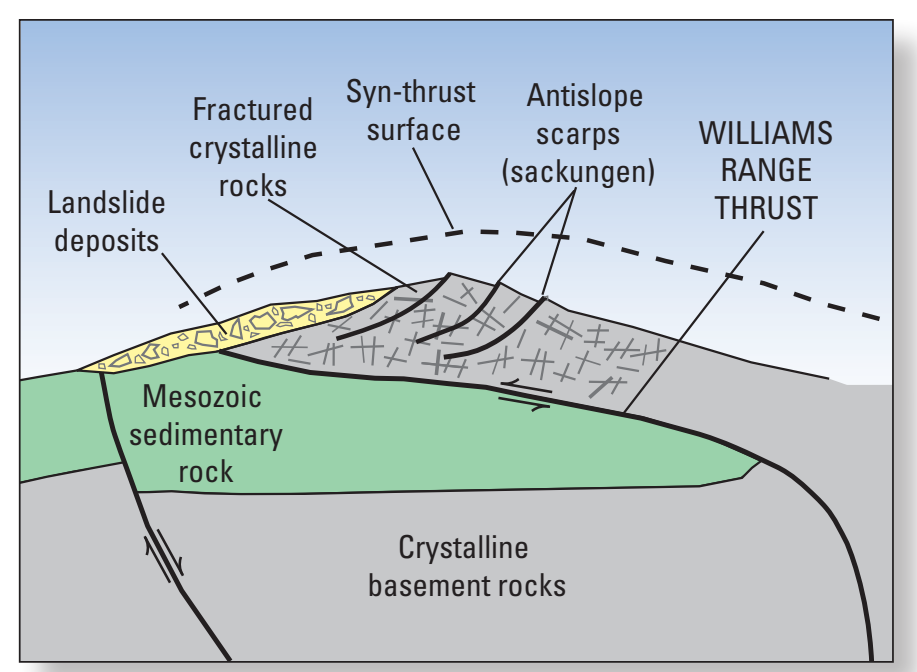

Figure 26. Schematic cross section through Williams Fork Mountains showing the development of sackungen and landslides as a result of pervasive fracturing.
Figure 27 (page 31). The Colorado Mineral Belt extends northeastward from the San Juan Mountains in the southwest part of Colorado to the Front Range near Boulder. The belt includes most of the major mining districts in the state (red dots); the Cripple Creek gold mine is a major exception. The Colorado Mineral Belt also contains many of the state's "fourteeners"mountain peaks more than 14,000 feet high. 


\section{Rich Ores of the Blue River Valley Region- Their Geology and Mining History}

If you look at a map of all major mining districts in Colorado, you will notice that most of them lie in a northeast-trending belt that extends from the southwestern corner of the state to Boulder. This belt is referred to as the Colorado Mineral Belt (fig. 27). It includes almost all of the major metal mining districts in the state-such as Aspen, Climax, Leadville, Silverton, and Telluride. The large gold mine at Cripple Creek, Colorado, is a major exception; it lies considerably east of the belt. All of the rich mines in Summit County lie along the Colorado Mineral Belt. It has been suggested that a huge, northeast-trending body of deeply buried Laramide and younger granite and related rocks provided the heat and mineralizing fluids that deposited the ores.

Historically, the richest gold deposits in Summit County were near Breckenridge, in gravel placer deposits along the upper Blue River, the Swan River (fig. 28), French Gulch, and Tenmile Creek (fig. 2). These gravels were dredged for 100 years, from 1859 to 1959 , although most of the gold was produced between 1906 and 1924. Total value of gold from these placers was more than $\$ 15.5$ million at then-current prices of $\$ 21$ /ounce to $\$ 35 /$ ounce (approximately $\$ 1.0$ billion at 2014 gold prices). A 29-oz gold nugget was reportedly found in gravel along the lower Swan River.

Hydraulic mining for gold used powerful streams of water shot from hoses aimed onto gravels; the resultant slurry was run through sluice boxes. At Mesa Cortina (figs. 2 and 24) near Silverthorne and at Gold Run near Breckenridge, hydraulic mining began in 1860 , and the gravelly deposits were worked intermittently until 1934; early miners called the Mesa Cortina gravels "buffalo placers." These deeply weathered gravels (fig. 24) may be as old as Pliocene and are probably debris-flow deposits or alluvium rather than pre-Bull Lake glacial deposits.

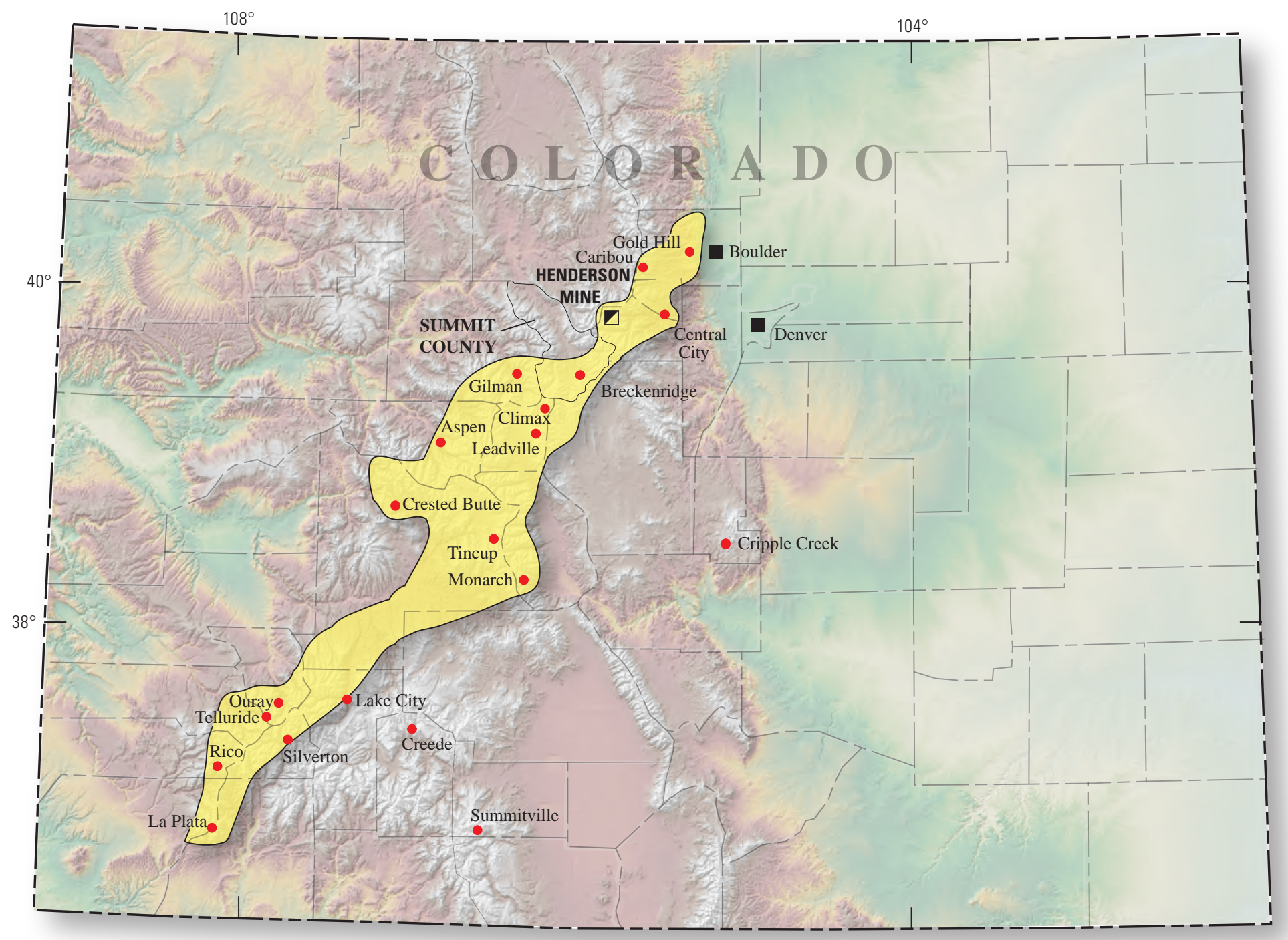




\section{Hard-Rock Mining in the Blue River Valley}

Hard-rock mining in the Breckenridge district commenced in 1869, and the beautiful gold wire, foil, and nuggets mined from the district, especially from Farncomb Hill about a mile north of French Gulch, are well-known items in many museum mineral collections. Gold was the principal commodity produced until the railroad to Leadville (and continuing on to Denver) was completed in 1880 , which gave access to smelters that could process ores containing lead, zinc, and copper. The Wellington mine, on French Gulch about 1.5 miles east of Breckenridge (fig. 29), was by far the largest gold mine in the district. In this mine, northeast-striking, southeast-dipping veins as wide as about 10 feet of galena (lead sulfide), sphalerite (zinc sulfide), copper-bearing minerals, and pyrite (iron sulfide) produced considerable amounts of gold, silver, lead, zinc, and copper. The mine operated until 1958 when it was permanently closed. During its last 10 years of operation alone, the Wellington mine produced about 2,320 ounces of gold, 174,000 ounces of silver, 116 million pounds of lead, 16.8 million pounds of zinc, and 464,000 pounds of copper.
Extensively mined deposits in the Gibson Hill area, just northeast of Breckenridge, are confined to a pervasively altered, 44-million-year-old granite porphyry (quartz monzonite porphyry, to be specific) laccolith, radial dikes surrounding the laccolith, and peripheral sills, all of which intrude Cretaceous shale, limestone, and sandstone. A laccolith is a flat-bottomed, domeshaped body that intruded between sedimentary beds. Intrusion breccia is common. Mineralization is essentially restricted to the porphyry, which contains a stockwork of gold-bearing, iron oxide-quartz veinlets; it is richest in the upper oxidized ("epigene") zone, which extends as much as 80 feet below the surface. Accompanying the quartz are, in decreasing order of relative abundance, massive, earthy, yellow and orange iron oxides and sulfate, fine white mica and, rarely, visible native gold. Deeper, unoxidized ("hypogene") ore includes, in decreasing order of abundance, pyrite, sphalerite, and galena. The presence of galena was thought to be a particularly favorable indication of nearby gold. A cluster of mines on the heavily worked north side of Gibson Hill produced at least 70,000 ounces and possibly as much as 170,000 ounces of gold.

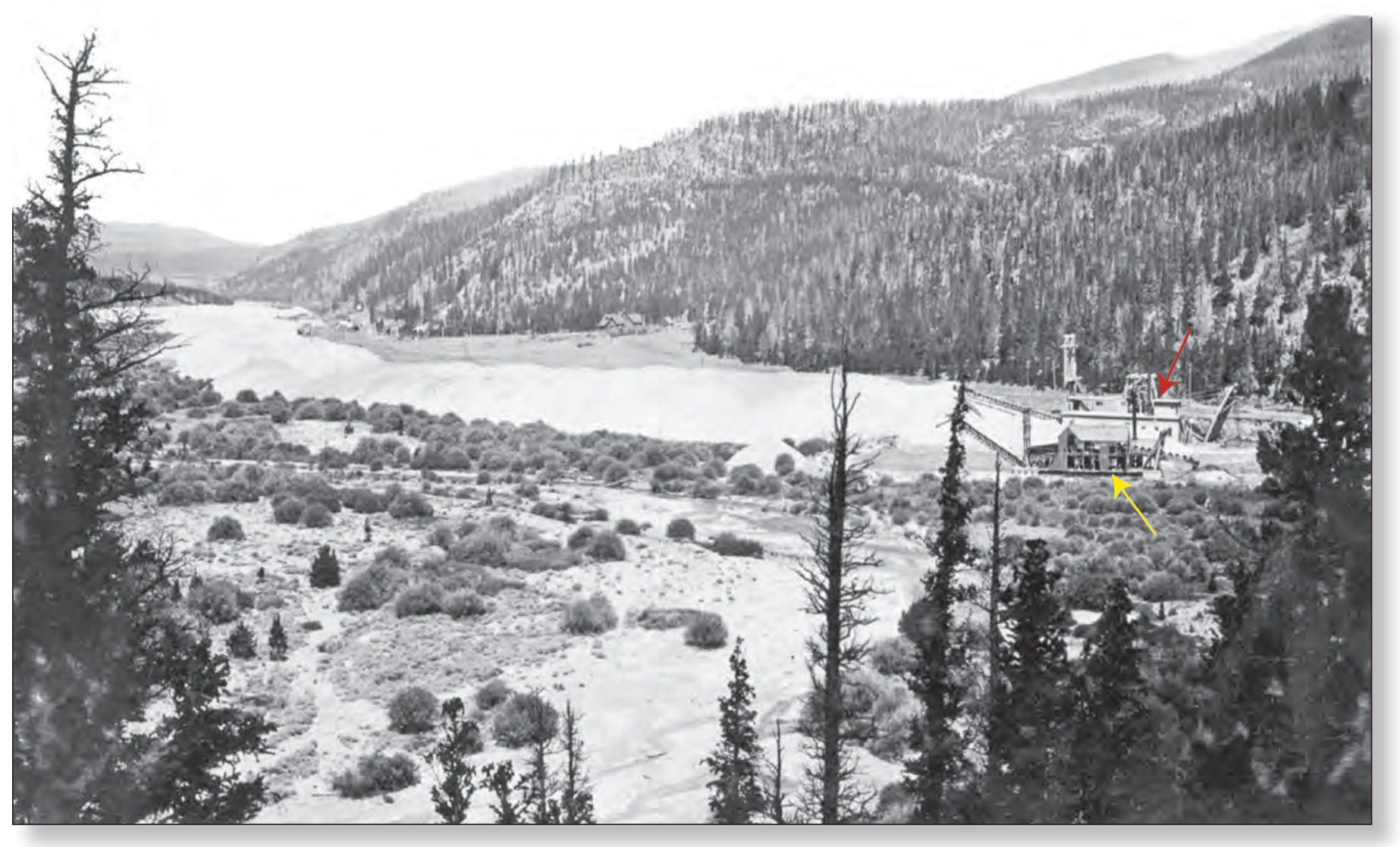

Figure 28. Gold dredge (red arrow) working up Swan River; view is to the north (downstream). The piles of gravel (placers) are the work of this dredge, which had worked down to the Blue River. The small, dilapidated machine (yellow arrow) in front of the larger craft is an old steam dredge. The dredges are long gone and the placer deposits now have been mostly smoothed for development. This photograph was taken in 1909 by the famous geologist Frederick L. Ransome, who extensively studied the Breckenridge mining district. 
Mines in the Montezuma district produced mainly silver and lead from pyrite-galena-sphalerite veins. The Saints John mine, discovered in 1865, is one of the oldest silver mines in the state and is known for the high-grade ruby silver ore mined there. Deep-red ruby silver is also called pyrargyrite $\left(\mathrm{Ag}_{3} \mathrm{SbS}_{2}\right)$.

Mines in the Kokomo district on Tenmile Creek exploited massive blanket-shaped deposits ("mantos") of lead, zinc, and silver sulfide that replaced limestone beds in the Minturn Formation (fig. 10). Minor amounts of gold were also recovered. Mining ceased in 1951 and the towns of Kokomo, Recon, and several other small settlements are now largely buried under the tailings and wasterock of the Climax mine in upper Tenmile Creek.

Several small mines in the Tenmile Range mostly operated in the latter part of the 19 th and early 20 th centuries. They produced gold, silver, lead, zinc, and copper from mixed-sulfide quartz veins cutting Proterozoic rock, although it has been said that in most cases, more money was put into the ground than was taken out. The ruins of one of these mines, the Boston mine, lie in Mayflower Gulch.
In the Gore Range, prospects or small mines containing lead, copper, zinc, and silver in quartz and quartz-carbonate veins were exploited during the latter part of the 19th and early 20th centuries. The largest of these, the Boss mine on the eastern side of the Gore Range, was mined for silver-bearing galena and sphalerite from east-dipping quartz veins in Proterozoic gneiss just west of the Blue River normal fault. A small but rich deposit of sphalerite and silver-bearing galena was mined between 1937 and 1950 at the Four Star mine, about 600 feet east of Green Mountain dam, from fracture fillings in sandstone of the Dakota Sandstone (fig. 10). This mineralization probably accompanied emplacement of the early Oligocene intrusive porphyry at Green Mountain.

Economically marginal fluorite or fluorspar (calcium fluoride) in a matrix of Dakota Sandstone fragments, called the Hammer fluorspar deposits, was mined from brecciated sandstone blocks in a landslide deposit about 3 miles northwest of Silverthorne. This fluorspar-bearing deposit was probably transported a significant distance to the east by landsliding from a now-buried, faulted and mineralized sandstone of the Dakota Sandstone.

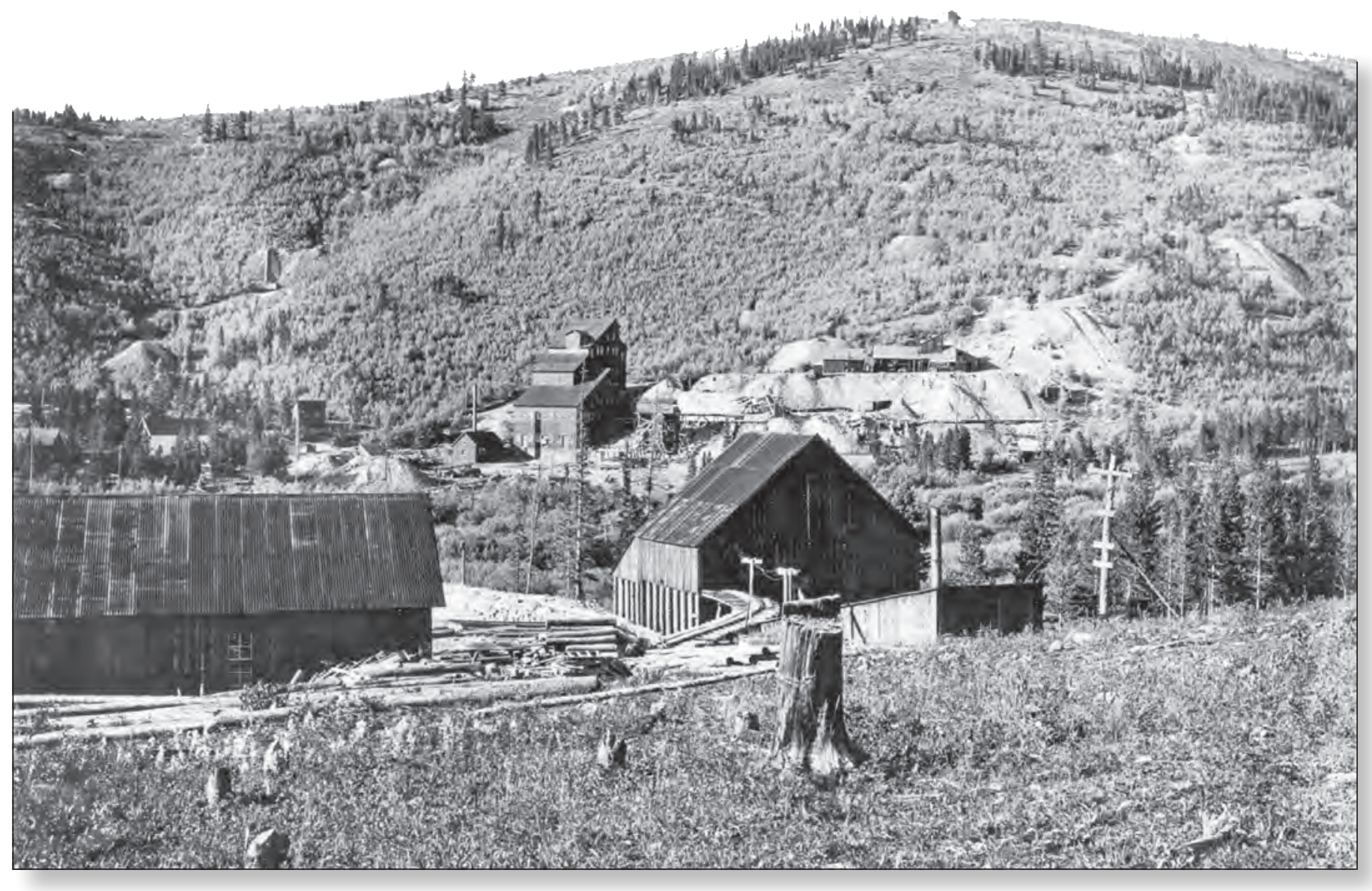

Figure 29. Wellington mine on French Gulch, Breckenridge mining district. Most of the mine dumps shown are from the Oro mine workings; the vein underlying the Oro workings lies diagonally up the hill to the right, nearly along the line of dumps. The Wellington mine is located near the contact between Dakota Sandstone and Morrison Formation, and the vein extends into adjacent Tertiary porphyritic granite. This photo was taken in 1909 by Frederick L. Ransome. 


\section{Raillroads and Mining}

The railroad history of Summit County and its environs is closely tied to the mining history. Transportation into and out of Summit County from 1860 to 1880 was by horse and wagon on primitive roads over the high passes, but transport of goods and mine products clearly got a huge boost with the advent of railroad service in the early 1880s. Railroads made it possible to supply substantial quantities of coal to power the smelters and mills and to ship the ore concentrates from the mills to the smelters. The ore was generally concentrated by a mill at or near the mine, but the nearest smelters were in Leadville, about 10 miles south of Summit County over Fremont Pass.

Two railroads competed to serve Summit County. The Denver, South Park and Pacific Railroad came from the east over Boreas Pass from South Park to Breckenridge. Its rail line went on to Frisco and then up Tenmile Creek to access the Kokomo mining district (now buried under mine tailings from the Climax mine in upper Tenmile Creek), and continued to Fremont Pass and eventually to Leadville. The other railroad, Denver and Rio Grande Railroad, was built from Leadville over Fremont Pass and down Tenmile Creek to the Blue River at Dillon (the original townsite is now under Dillon Reservoir), and then east to Keystone; the planned continuation to Montezuma was never completed.

As mining declined and automobiles and trucks and the roads on which they traveled improved, the railroads were abandoned. The Denver and Rio Grande Railroad from Leadville to Dillon was abandoned in 1924, and its roadbed, except a stretch above the Climax tailings ponds, is followed by the present highway up Tenmile Creek. Looking across Tenmile Creek from the highway, one can see parts of the roadbed of the Denver, South Park, and Pacific Railroad that came from Breckenridge. This line was abandoned in 1938 and the section over Boreas Pass is now a gravel road that is closed during the winter.

\section{Climax Molybdenum Deposit}

The Climax mine near Fremont Pass, currently operated by Freeport-McMoRan Copper and Gold, is reported to be the largest, highest-grade, and lowest-cost molybdenum ore body in the world. The mine is in Lake County, just south of the Summit County line (fig. 2), although extensive tailings ponds from the mine lie along the headwaters of Tenmile Creek in Summit County. Molybdenum's many uses include alloys with steels to make hardened automotive and jet-turbine parts, construction equipment, stainless steel, tool steel, lubricants, automobile safety airbags, and an agent used for removing sulfur from crude oil.

The deposit was discovered in 1879 by Charles Senter during the Leadville silver boom, but he did not know what the silvery-gray, greasy mineral (molybdenite, $\mathrm{MoS}_{2}$ ) was until a chemist analyzed it in 1895. At that time, molybdenum had no commercial value, and it was not until it was discovered to harden steel that an industry was born. Commercial production began in 1915, and by the close of World War I, Climax was producing 90 percent of the world's molybdenum. The price of molybdenum crashed after the war, and the mine shut down until 1924, when peace-time uses for molybdenum-hardened steel again made mining profitable. By 1959, Climax produced 35,000 tons/day of ore and was the world's largest underground mine. These underground workings have mostly collapsed (purposefully "block-caved" by removing supporting rock) into a gigantic "glory hole," testifying to the extent of these underground workings. Starting in about 1972, large-scale open-pit mining began, and the benches of that phase can be seen above the glory hole on the steep mountainside. For obvious reasons, mining at this time was restricted to areas not already caved into the glory hole.

Between 1915 and 1987, the Climax mine produced 421.5 million tons of ore, yielding 1,885 million pounds (almost a million tons) of molybdenum. This massive production created an enormous problem, however: where was all the mine waste to be placed? The solution was to use almost the entire upper reach of Tenmile Valley for storing tailings, thereby burying almost the entire Kokomo mining district, including the small towns of Recon, Kokomo, Robinson, and Carbonateville, although most of them were ghost towns by then.

The high price of molybdenum caused many porphyry copper mines (in which mineralization was caused by a porphyritic granite) to begin producing the metal as a byproduct of copper production, which flooded the market and caused the price to drop. The Climax mine could not compete, and the mine was placed on an inactive status in 1995. However, as the price of molybdenum once again increased sufficiently, the mine was put back into production in 2012. As of 2014, recoverable reserves are estimated at 145 million tons of ore, averaging 0.23 percent molybdenum, which amounts to about 335 million pounds of molybdenum. It is interesting to consider that before erosion removed most of the richest ore, the deposit may have contained as much as 4 million tons of minable molybdenum, making it, as far as is known, the world's greatest deposit of molybdenite. 
The deposit is composed of a stockwork of molybdenite in small veinlets associated with multiple high-silica granitic porphyry stocks and rhyolite dikes containing elevated amounts of fluorine, molybdenum, tin, tungsten, uranium, thorium, and niobium. The ore occurs in three separate dome-shaped shells, each of which is associated with a separate granitic intrusion, which collectively form an intrusive complex, emplaced during a 9-million-year period from 33 to 24 million years ago. The molybdenite stockwork is associated with pervasive deposition of potassium feldspar and is just above a zone of massive "flooding" of silica-rich fluids that produced much secondary quartz. A western, unmined, part of the ore body is dropped down several thousand feet below the elevation of the main ore zone along the down-on-the-west Mosquito fault (fig. 7), which moved mostly during late Oligocene and Miocene crustal extension associated with formation of the Rio Grande rift.

Beside molybdenum, the mine has also yielded tin, tungsten, copper, rare-earth elements, and pyrite (used in the production of sulfuric acid) as byproducts. Sulfides are separated by the froth-flotation process, and waste from this process now underlies the large tailings ponds along Tenmile Creek. Water that flows from the ponds is treated to remove heavy metals and reduce acidity before being released into Tenmile Creek. A dense network of diversion canals intercepts water from all streams draining into the ponds and diverts it around the tailings ponds, thus minimizing contamination of downstream areas. Efforts are currently underway to reclaim some of the tailings by spreading top soil and planting trees.

\section{Acknowledgments}

This booklet was improved tremendously by reviews and conversations with Jack Reed, Jr., and Ric Page of the U.S. Geological Survey. Mary-Margaret Coates further improved the booklet with careful editing, and Carol Quesenberry brought it to life with her artistic layout. The authors wish to thank them for their valuable input. 


\section{Suggested Reading}

\section{Age of the Rocks and Uplift History}

Bryant, Bruce, Marvin, R.F., Naeser, C.W., and Mehnert, H.H., 1981, Ages of igneous rocks in the South Park-Breckenridge region, Colorado, and their relation to the tectonic history of the Front Range uplift, Chapter C, in Shorter contributions to isotope research in the western United States, 1980: U.S. Geological Survey Professional Paper 1199, p. 15-26.

Kellogg, K.S., Shroba, R.R., Premo, W.R., and Bryant, Bruce, 2011, Geologic map of the eastern half of the Vail 30' x 60' quadrangle, Eagle, Summit, and Grand Counties, Colorado: U.S. Geological Survey Scientific Investigations Map 3170, scale 1:100,000, with 49 p. pamphlet.

Naeser, C.W., Bryant, B., Kunk, M.J., Kellogg, K.S., Donelick, R.A., and Perry, W.J., Jr., 2002, Tertiary cooling and tectonic history of the White River uplift, Gore Range, and western Front Range, central Colorado-Evidence from fission-track and ${ }^{40} \mathrm{Ar} /{ }^{39} \mathrm{Ar}$ ages, in Kirkham, R.M., Scott, R.B., and Judkins, T.W., eds., Late Cenozoic evaporite tectonism and volcanism in west-central Colorado: Geological Society of America Special Paper 366, p. 31-53.

U.S. Geological Survey Geologic Names Committee, 2010, Divisions of geologic time-Major chronostratigraphic and geochronologic units: U.S. Geological Survey Fact Sheet 2010-3059, 2 p.

\section{The Laramide Orogeny}

Tweto, Ogden, 1975, Laramide (Late Cretaceous-early Tertiary) orogeny in the Southern Rocky Mountains, in Curtis, Bruce, ed., Cenozoic history of the Southern Rocky Mountains: Geological Society of America Memoir 144, p. 1-44.

\section{Ore Deposits}

Bookstrom, A.A., 1990, Igneous rocks and carbonate-hosted ore deposits of the central Colorado Mineral Belt, in Beatty, D.W., Landis, G.P., and Thompson, T.B., eds., Carbonate-hosted sulfide deposits of the central Colorado Mineral Belt: Economic Geology Monograph 7, p. 45-65.

Lovering, T.S., 1934, Geology and ore deposits of the Breckenridge mining district, Colorado: U.S. Geological Survey Professional Paper 176, 64 p.

Lovering, T.S., 1935, Geology and ore deposits of the Montezuma quadrangle, Colorado: U.S. Geological Survey Professional Paper 178, 119 p.

Parker, B.H., Jr., 1974, Gold placers of Colorado (Book 1): Quarterly of the Colorado School of Mines, v. 69, no. 3, 268 p.

Ransome, F.L., 1911, Geology and ore deposits of the Breckenridge district, Colorado: U.S. Geological Survey Professional Paper 75, 187 p.

Singewald, Q.D., 1951, Geology and ore deposits of the upper Blue River area, Summit County, Colorado: U.S. Geological Survey Bulletin 970, 74 p.

Wallace, S.R., and Snow, G.G., 1980, The porphyry molybdenite deposit at Climax, Colorado, in Bryant, Bruce, and Beaty, D.W., eds., Mineral deposits and geology of central Colorado: American Geophysical Union field trip guidebook T129, p. 38-44. 


\section{Precambrian History}

Reed, J.C., Jr., Bickford, M.E., and Tweto, Ogden, 1993, Proterozoic accretionary terranes of Colorado and southern Wyoming, in Van Schmus, W.R., and Bickford, M.E., eds., Transcontinental Proterozoic provinces, in Reed, J.C., Jr., and six others, eds., Precambrian conterminous U.S.: Geological Society of America, The geology of North America, v. C-2, p. 211-228.

Tweto, Ogden, 1987, Rock units of the Precambrian basement in Colorado: U.S. Geological Survey Professional Paper 1321-A, 54 p.

\section{Quaternary History}

Chadwick, O.A., Hall, R.D., and Phillips, F.M., 1997, Chronology of Pleistocene glacial advances in the central Rocky Mountains: Geological Society of America Bulletin, v. 109, p. 1443-1452.

Kellogg, K.S., 2001, Tectonic controls on a large landslide complex-Williams Fork Mountains near Dillon, Colorado: Geomorphology, v. 41, p. 355-368.

Varnes, D.J., Radbruch-Hall, D.H., and Savage, W.Z., 1989, Topographic and structural conditions in areas of gravitational spreading of ridges in the western United States: U.S. Geological Survey Professional Paper 1496, 28 p.

West, M.V., 1978, Quaternary geology and reported surface faulting along east flank of Gore Range, Summit County, Colorado: Quarterly of the Colorado School of Mines, v. 73, no. 2, 66 p.

\section{Railroad History}

Ormes, Robert, 1975, Tracking ghost railroads in Colorado: Colorado Springs, Colorado, Century One Press, 148 p.

\section{Regional Geology (including maps; some references also include discussion of ore deposits)}

Bergendahl, M.H., 1963, Geology of the northern part of the Tenmile Range, Summit County, Colorado: U.S. Geological Survey Bulletin 1162-D, scale 1:24,000, 19 p.

Chronic, Halka, and Williams, Felicie, 2002, Roadside geology of Colorado: Missoula, Montana, Mountain Press Publishing Company, 399 p.

Kellogg, K.S., Bartos, P.J., and Williams, C.L., 2002, Geologic map of the Frisco quadrangle, Summit County, Colorado: U.S. Geological Survey Miscellaneous Field Studies Map MF-2340, scale 1:24,000.

Kellogg, K.S., Shroba, R.R., Bryant, Bruce, and Premo, W.R., 2008, Geologic map of the Denver West 30' × 60' quadrangle, Colorado: U.S. Geological Survey Scientific Investigations Map 3000, scale 1:100,000.

Kellogg, K.S., Shroba, R.R., Premo, W.R., and Bryant, Bruce, 2011, Geologic map of the eastern half of the Vail $30^{\prime} \times 60^{\prime}$ quadrangle, Eagle, Summit, and Grand Counties, Colorado: U.S. Geological Survey Scientific Investigations Map 3170, scale 1:100,000.

Matthews, Vince, Landon, Susan, and KellerLynn, Katie, eds., 2003, Messages in stoneColorado's colorful geology: Colorado Geological Survey, 157 p. 
Tweto, Ogden, Bryant, Bruce, and Williams, F.E., 1970, Mineral resources of the Gore RangeEagles Nest Primitive Area and vicinity, Summit and Eagle Counties, Colorado:

U.S. Geological Survey Bulletin 1319-C, 127 p.

Tweto, Ogden, Moench, R.H., and Reed, J.C., Jr., 1978, Geologic map of the Leadville $1^{\circ} \times 2^{\circ}$ quadrangle, northeastern Colorado: U.S. Geological Survey Miscellaneous Investigations Series Map I-999, scale 1:250,000.

Wallace, C.A., Keller, J.W., McCalpin, J.P., Bartos, P.J., Route, E.E., Jones, N.N., Gutierrez, Francisco, Williams, C.L., and Morgan, M.L., 2003, Geologic map of the Breckenridge quadrangle, Summit and Park Counties, Colorado: Colorado Geological Survey Open-File Report $02-7$, scale 1:24,000. (Contains a particularly good overview of mineral deposits in the area.)

Widmann, B.L., Bartos, P.J., McCalpin, and Jackson, Jeffrey, 2004, Geologic map of the Copper Mountain quadrangle, Summit, Eagle, Lake, and Park Counties, Colorado: Colorado Geological Survey Open-File Report 03-20, scale 1:24,000.

\section{Rio Grande Rift}

Chapin, C.E., and Cather, S.M., 1994, Tectonic setting of the axial basins of the northern and central Rio Grande rift, in Keller, G.R., and Cather, S.M., eds., Basins of the Rio Grande rift—Structure, stratigraphy, and tectonic setting: Geological Society of America Special Paper 291, p. 5-25.

Kellogg, K.S., 1999, Neogene basins of the northern Rio Grande rift—Partitioning and asymmetry inherited from Laramide and older uplifts: Tectonophysics, v. 305, p. 141-152.

Tweto, Ogden, 1979, The Rio Grande rift system in Colorado, in Riecker, R.E., ed., Rio Grande rift-Tectonics and magmatism: Washington, D.C., American Geophysical Union, p. 33-56.

\section{Seismic History}

Spence, William, Langer, C.J., and Choy, G.L., 1996, Rare, large earthquakes at the Laramide deformation front, Colorado (1882) and Wyoming (1984): Bulletin of the Seismological Society of America, v. 86, p. 1804-1819. 


\section{Glossary}

\section{A}

alluvial fan A cone- or fan-shaped deposit composed of sediments deposited by debris flows and streams where a smaller (tributary) valley adjoins a more level surface in a larger valley.

aluminosilicate A mineral in which aluminum substitutes for silica in part of the crystal structure.

ammonite A member of an extinct group of cephalopods, related to squids, octopuses, and chambered nautili that have a thick, intricately ornamented, segmented shell. Ammonites died out at the end of the Paleozoic Era and their fossil remains are valuable for identifying the age of the rocks in which they occur.

amphibole Group of generally dark (commonly black) aluminosilicate minerals that has a prismatic, elongate form; various proportions of iron and magnesium produce the dark color.

amphibolite A black or dark-gray metamorphic rock composed almost entirely of amphibole (variety hornblende) and plagioclase; amphibole is greater than 50 percent of rock; commonly interpreted as metamorphosed basalt or andesite.

anticline A convex-upward (arch-shaped) fold in layered rocks, such that the oldest rocks are in the center of the fold.

apatite fission-track age Age determined from counting density of fission tracks in a highly polished slide containing the mineral apatite $\left(\mathrm{CaPO}_{4}\right)$. Fission tracks are produced by high-speed particles released from the spontaneous decay of ${ }^{238} \mathrm{U}$. The tracks generally are retained below about $100{ }^{\circ} \mathrm{C}$ (and are annealed, or disappear, above this temperature), so the calculated age gives the time at which the rock containing the apatite cooled through $100{ }^{\circ} \mathrm{C}$. This calculated age is commonly used to reconstruct the rock unit's uplift history, because rock at depth, which is hot owing to the geothermal gradient in the Earth's crust, cools as an area is uplifted and overlying rock is removed by erosion.

andesite Fine-grained, dark-colored extrusive rock, commonly containing phenocrysts of sodic plagioclase; slightly more silicic than a basalt and less silicic than a dacite.

ash-flow tuff A generally hard, fine-grained, rock formed from an incandescent cloud erupted from a volcano; sometimes called an ignimbrite.

\section{B}

basalt Black, fine-grained volcanic rock, commonly containing phenocrysts of hornblende, pyroxene, and olivine, but little or no quartz.

basement The complex of igneous and metamorphic rocks that underlies sedimentary rocks and deposits or is exposed at the surface.

batholith An igneous intrusion that has at least 40 square miles of surface exposure and no known floor.

biotite Platy black aluminosilicate mineral, a type of mica, common in igneous and metamorphic rocks; contains potassium and various proportions of iron and magnesium; common mineral in biotite gneiss.

breccia A rock composed of angular fragments usually bound together by a fine-grained matrix; may be formed in a fault zone or a debris flow. 
calcareous Said of a rock or deposit that contains calcium carbonate.

calc-silicate gneiss A metamorphic rock consisting mainly of calcium-bearing silicate minerals and formed by metamorphism of impure limestone or dolomite.

cephalopod A marine mollusk belonging to the class Cephalopoda; includes octopuses, squids, chambered nautili, and extinct ammonites.

clastic Pertaining to a rock or sediment composed principally of broken or eroded fragments (clasts) that are derived from preexisting rocks that have been transported some distance from their place of origin; sandstone and conglomerate are examples.

cross section Diagram of a slice through the Earth that shows subsurface geology.

D

dacite Generally gray, fine-grained, extrusive or intrusive igneous rock, commonly containing phenocrysts of plagioclase and quartz; fine-grained equivalent of granodiorite.

dike A tabular igneous intrusion that cuts across surrounding rock.

dip The angle that a sloping surface makes with the horizontal; measured perpendicular to the strike of the surface.

dolomite A carbonate sedimentary rock resembling limestone containing the mineral dolomite $\left(\mathrm{CaMg}\left(\mathrm{CO}_{3}\right)_{2}\right)$; the rock commonly forms by addition of magnesium to existing limestone.

$\mathbf{F}$

feldspar Common rock-forming aluminosilicate mineral with wide compositional range; two major groups are plagioclase [sodium-calcium feldspar $\left.(\mathrm{Na}, \mathrm{Ca}) \mathrm{Al}(\mathrm{Si}, \mathrm{Al}) \mathrm{Si}_{2} \mathrm{O}_{8}\right)$ ] and potassium feldspar $\left(\mathrm{KAlSi}_{3} \mathrm{O}_{8}\right)$.

felsic Refers to an igneous rock containing an abundance of light-colored minerals; an adjective derived from shortened forms of "feldspar" plus "silica."

fluorite Calcium fluoride $\left(\mathrm{CaF}_{2}\right)$, a translucent mineral commonly found in veins associated with ores of lead, tin, and zinc; usually purple or blue.

fluvial An adjective pertaining to a river or stream.

foliation A general term for a planar arrangement of textural or structural features, such as mineral grains, in a rock; usually refers to the layering in a metamorphic or igneous rock.

froth-flotation process A method of separating sulfide minerals, such as galena, sphalerite, molybdenite, and pyrite from waste rock. Ground ore is placed in a vat with 1 percent pine oil or turpentine and water. Forced air forms an oily froth which adheres to the sulfides (but not the silicate minerals) when the mixture is agitated. The sulfide-rich froth is skimmed off, the sulfides are separated, and the pine oil or turpentine is recycled. 
gabbro Dark colored, medium- to coarse-grained intrusive rock containing calcic plagioclase; black, iron-magnesium minerals; and little or no quartz; coarse-grained equivalent of basalt.

glory hole A large open pit from which ore is being or has been extracted; some glory holes form by purposeful collapse (block caving) of underground mine workings, such as at Climax.

gneiss A foliated metamorphic rock in which minerals are aligned in response to stress during regional metamorphism.

graben Elongate, down-dropped block bounded by normal faults, produced during crustal extension; a rift valley. A half-graben is bounded only on one side by a fault or faults, so it tilts into the bounding fault (or faults), such as in the Blue River half-graben.

granite A medium- to coarse-grained intrusive or plutonic rock containing approximately equal amounts of plagioclase and potassium feldspar and greater than 20 percent quartz. In most cases in the text, "granite" refers to a rock that contains a plagioclase/potassium-feldspar ratio of 35 to 65 percent (a monzogranite).

gypsum Hydrated calcium sulfate $\left(\mathrm{CaSO}_{4} \cdot 2 \mathrm{H}_{2} \mathrm{O}\right)$; an evaporite mineral.

\section{H}

halite Common salt $(\mathrm{NaCl})$; an evaporite mineral.

hornblende A black amphibole mineral, common in dark igneous and metamorphic rocks such as basalt, gabbro, or amphibolite.

\section{I}

igneous rock A rock formed by the solidification of a magma, such as basalt or granite. intrusion A body of igneous rock (batholith, stock, or dike) that penetrates Earth's crust. intrusion breccia A mixture of angular fragments of surrounding rocks that has been forcibly injected into a preexisting zone of weakness; may include an igneous component in the matrix and is generally very altered to clays and other minerals.

isotope One of two or more species of the same chemical element, differing only in the number of neutrons in the nucleus; isotopes of the same element have the same number of protons, but have slightly different physical and chemical qualities owing to their mass differences, by which they can be separated.

L

laccolith A dome-shaped igneous body, generally with a flat floor that intrudes parallel (concordant) to preexisting layers or beds; less than 5 miles in diameter.

Laramide A period of mountain building and igneous activity in western North America from the Late Cretaceous to the early Eocene (about 70-50 million years ago); the Laramide orogeny.

latite A porphyritic extrusive rock containing roughly equal amounts of plagioclase and potassium feldspar, little or no quartz, and a fine-grained to glassy matrix.

limestone A sedimentary rock composed mostly or entirely of the fine-grained mineral calcite $\left(\mathrm{CaCO}_{3}\right)$. 
M

magma Naturally occurring molten rock material, generated within the Earth, capable of extrusion (such as a lava) or of intrusion. It solidifies into an igneous rock that may or may not contain crystals and rock fragments.

manto A flat-lying, bedded ore deposit, generally following a sedimentary bed.

metamorphic rock A rock that has recrystallized owing to a variable combination of heat and pressure (commonly induced by deep burial or proximity to an igneous intrusion). For example, shale may metamorphose into a schist or gneiss.

metasedimentary A metamorphic rock derived from metamorphism of a sedimentary rock.

migmatite A rock containing interlayered metamorphic and igneous phases; the igneous phase is commonly granitic in texture and composition and may be produced by in-place partial melting of the metamorphic phase or by injection from elsewhere.

moraine A mound, ridge, or other distinct accumulation of glacial debris (till) left after melting of a glacier.

mylonite A very fine grained, hard, banded or streaky rock produced by intense shearing.

N

normal fault An inclined fault produced by extension in the Earth's crust, such that the rocks above the fault plane move down the fault, resulting in younger rocks overlying older rocks across the fault. The Blue River normal fault is an example.

0

orogeny A period of crustal deformation; a mountain-building event.

$\mathbf{P}$

pegmatite A very coarse-grained intrusive igneous rock usually found in dikes and pods in or near the margins of batholiths (large bodies of granitic rock); generally has the composition of a granite (roughly equal amounts of plagioclase, potassium feldspar, and quartz, with abundant mica); some feldspar or quartz crystals may be longer than one foot.

periglacial Processes or conditions that are active near margins of glaciers or in regions subject to intense freeze-thaw processes, such as alpine environments. Periglacial deposits commonly contain angular blocks derived from underlying bedrock and include block fields and bouldery stone stripes on hillsides formed by downslope creep.

plagioclase A white to gray, common rock-forming mineral; sodium-calcium aluminosilicate $\left[(\mathrm{Na}, \mathrm{Ca}) \mathrm{Al}(\mathrm{Si}, \mathrm{Al}) \mathrm{Si}_{2} \mathrm{O}_{8}\right]$.

phenocryst A visible crystal in an igneous rock, surrounded by a finer-grained matrix.

pluton A body of igneous rock that formed beneath the Earth's surface from consolidation of a magma.

porphyry An igneous rock containing phenocrysts in a finer-grained matrix.

potassium feldspar A light-pink to white, common rock-forming mineral; potassium aluminosilicate $\left(\mathrm{KAlSi}_{3} \mathrm{O}_{8}\right.$ ); a major constituent of granitic rocks.

pyroxene A black, equant, iron-magnesium aluminosilicate mineral, common in dark igneous rocks such as basalt and gabbro. 
quartz Silicon dioxide $\left(\mathrm{SiO}_{2}\right)$; one of the most common rock-forming minerals.

quartzite A granular metamorphic rock composed entirely of quartz grains; informally, also refers to a hard quartz sandstone in which quartz grains are cemented by silica $\left(\mathrm{SiO}_{2}\right)$.

quartz monzonite A medium- to coarse-grained intrusive rock containing approximately equal amounts of plagioclase and potassium feldspar and less than 20 percent quartz; informally, a relatively low-quartz granite.

\section{$\mathbf{R}$}

relief Refers to the physical shape or unevenness of the Earth's surface. A low-rolling or flat region is a surface of low relief; a mountainous or deeply incised region is a surface of high relief.

reverse fault A fault with a plane that slopes (dips) greater than $45^{\circ}$ toward the block that has been relatively raised; indicative of crustal shortening.

rhyolite A fine-grained, generally porphyritic igneous rock, commonly containing phenocrysts of quartz and potassium feldspar (generally a variety called sanidine). May originate either from volcanic activity or in shallow intrusive bodies.

\section{S}

sackung A deep-seated, trench-like fissure produced by gravitational spreading of a mountain range or ridge. Forms uphill-facing scarps and small ridge-top grabens.

sanidine A variety of high-temperature, clear potassium feldspar commonly found in volcanic rocks such as trachyte and rhyolite.

scarp A steep slope or zone produced by erosion, sliding, or faulting; the head of a younger landslide is commonly marked by a scarp.

schist A strongly foliated, commonly layered, crystalline rock, formed by regional dynamic metamorphism (metamorphism accompanied by shearing); rich in mica, so that it can be split into thin flakes or slabs.

sedimentary rock A rock, such as sandstone, shale, or limestone, that has resulted from the consolidation or cementation of loose sediment.

sill An igneous intrusion injected parallel to the layers of existing rock, such as sedimentary beds, producing an approximate tabular form.

stock An igneous intrusion that is less than about 60 square miles in area, and generally crosscuts (is discordant to) the surrounding rock. Smaller than a batholith, which is greater than 60 square miles in area.

stockwork A mineral deposit composed of a three-dimensional network of closely spaced veins that are dense enough that the entire mass can be mined.

strike The direction or trend of a horizontal line contained in a sloping surface; perpendicular to the dip of the surface.

strike-slip fault A steep fault in which the two sides move horizontally with respect to each other.

surficial deposit Unconsolidated material, mostly Quaternary in age, at or near the Earth's surface, such as alluvium, glacial till, and landslide deposits.

syncline A concave-upward (trough-shaped) fold in layered rocks, such that the youngest rocks are in the center of the fold. 


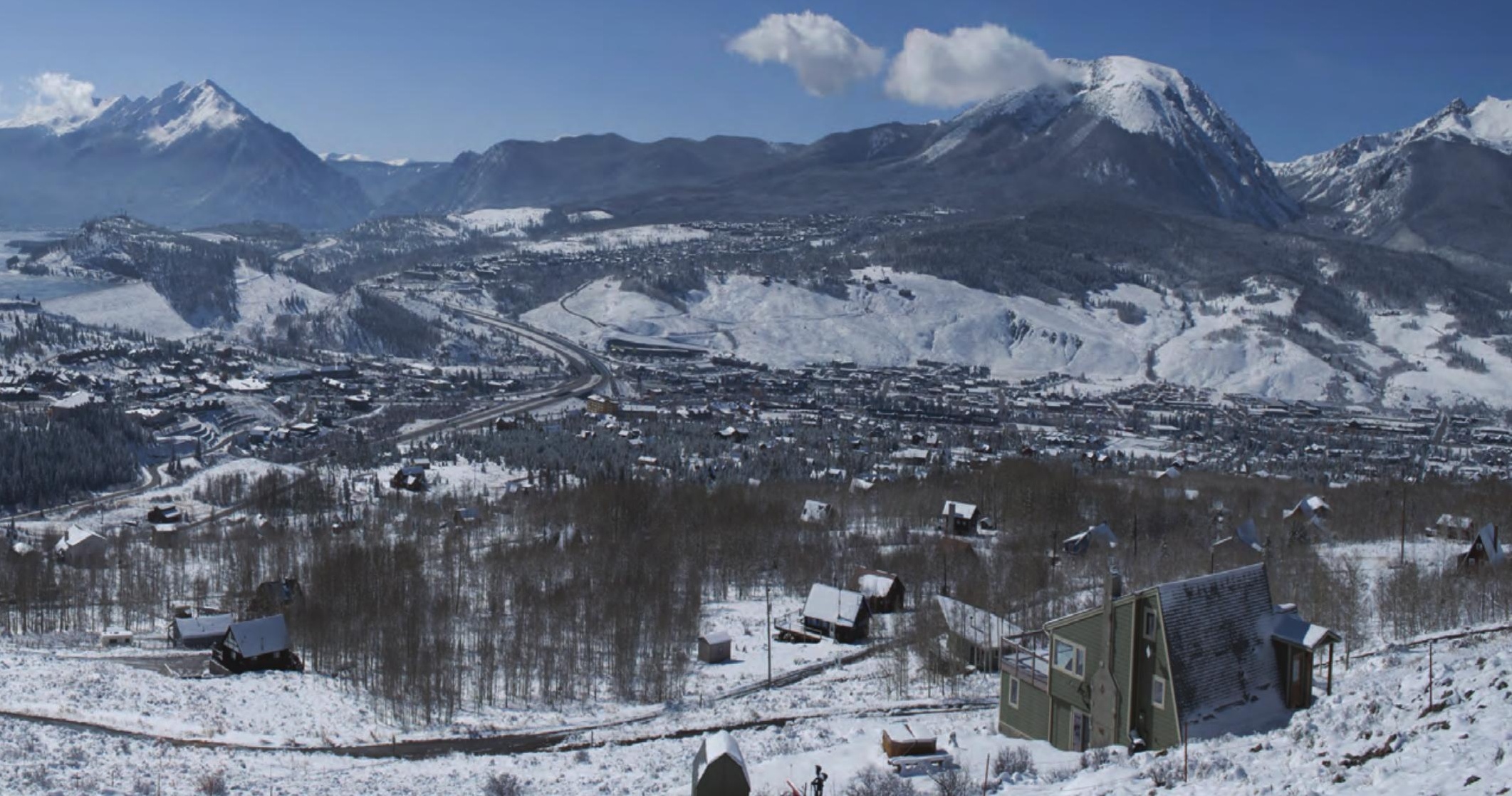



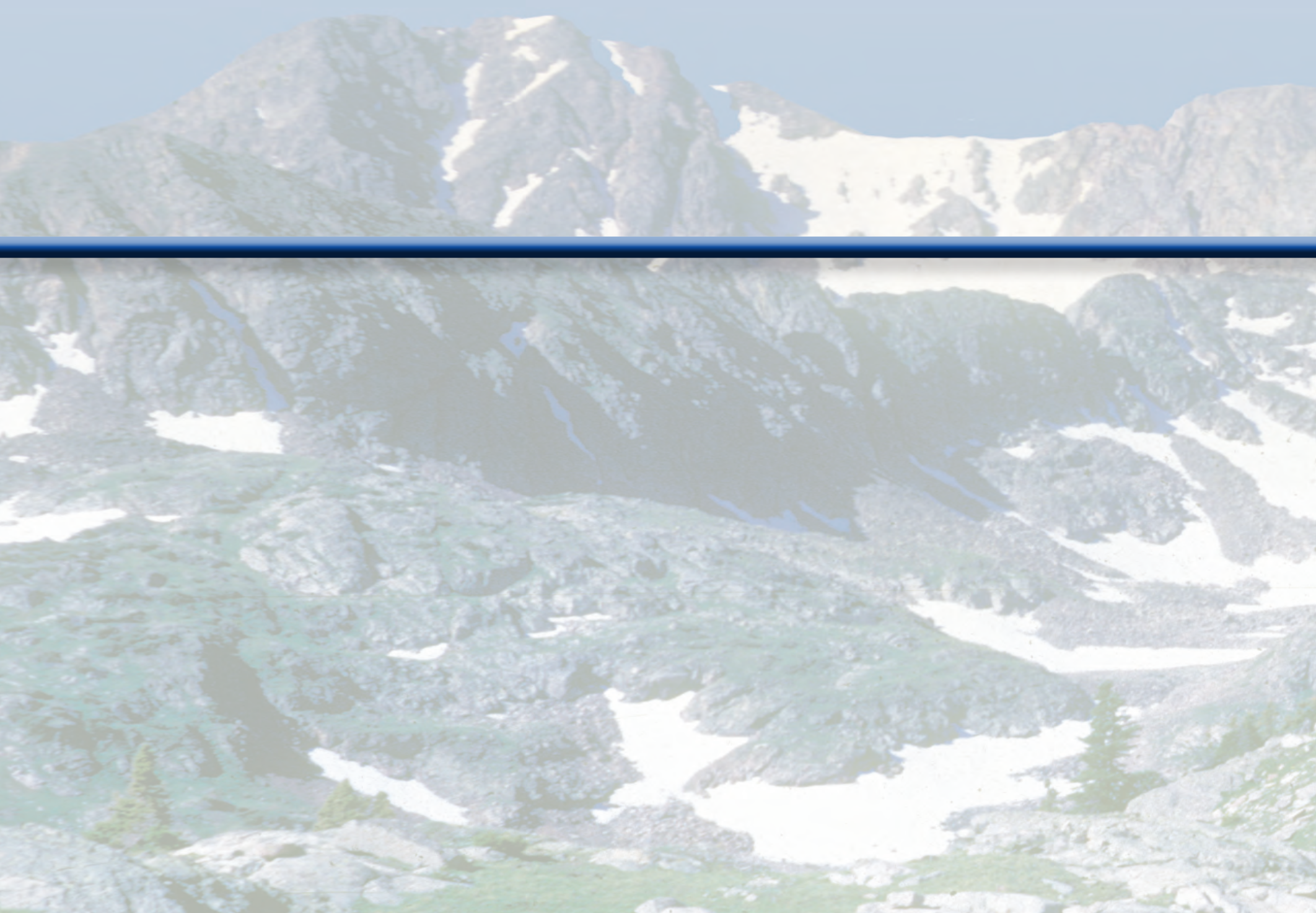

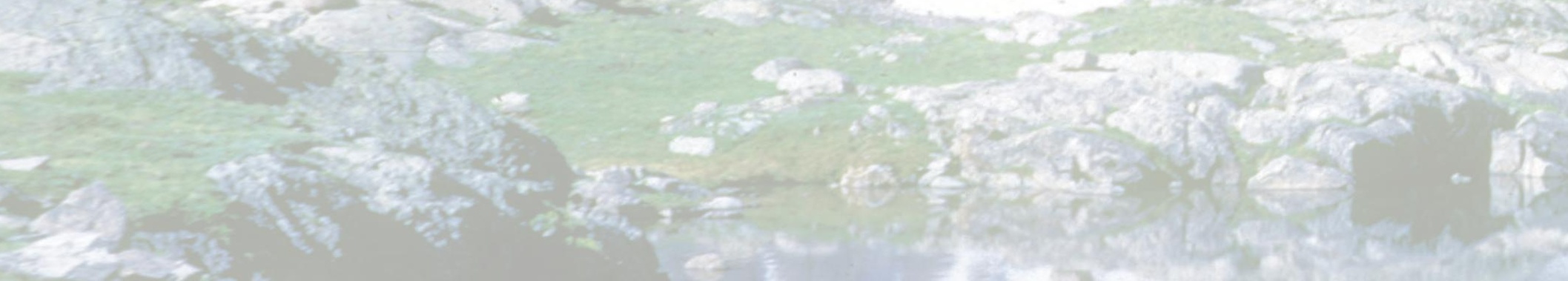

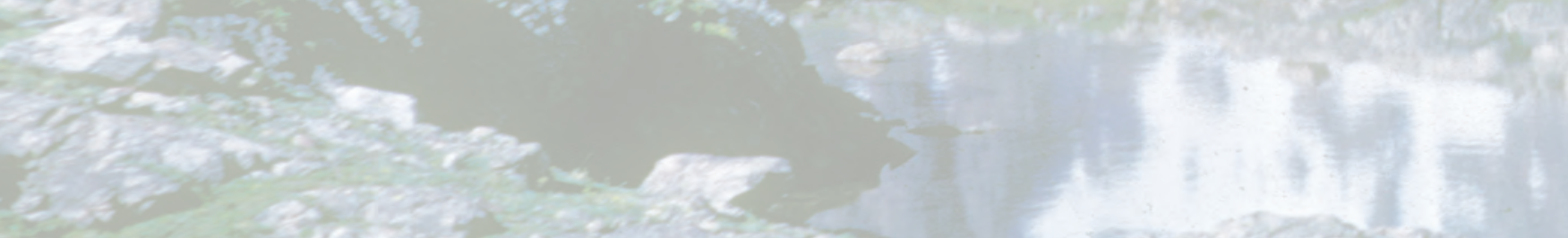




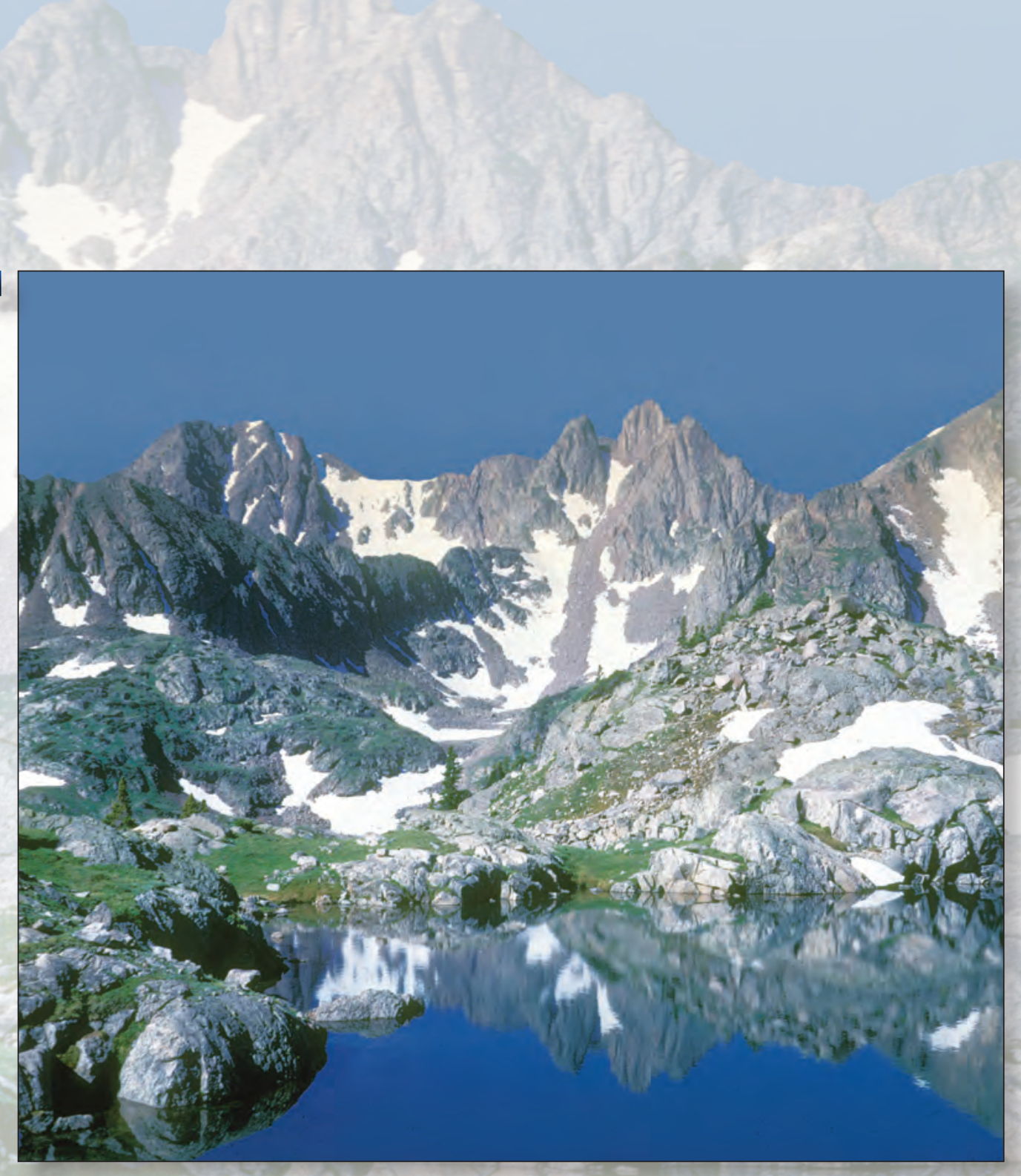

\section{Publishing support provided by Denver Publishing Service Center}

Edited by Mary-Margaret Coates

Illustrations by Mary Berger

Layout and graphic design by Carol A. Quesenberry

For more information concerning this publication, contact:

Center Director, USGS Geosciences and Environmental Change Science Center

Box 25046, Mail Stop 980

Denver, CO 80225

(303) 236-5344

Or visit the Geosciences and Environmental Change Science Center Web site at: http://gec.cr.usgs.gov/

This publication is available online at: http://dx.doi.org/10.3133/cir1400 


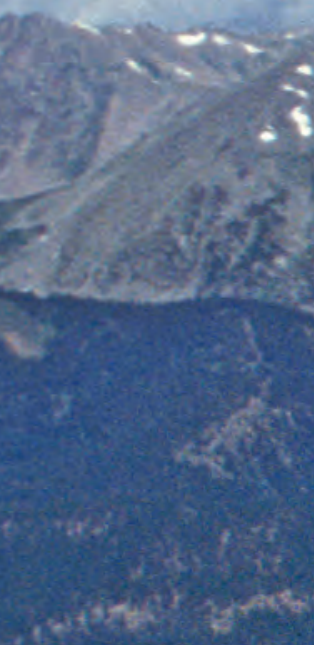

(6)

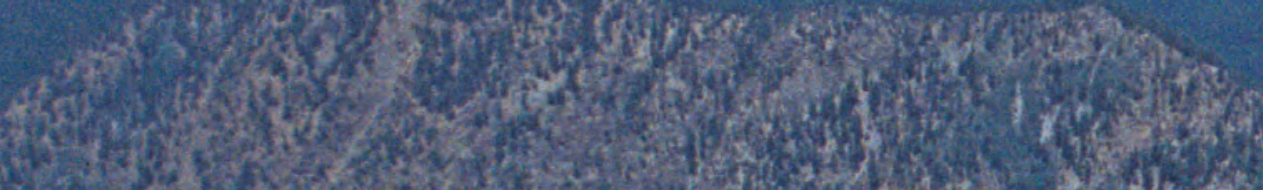

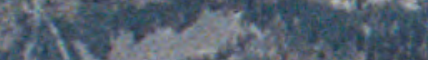
95 5. $3+1$ (1)

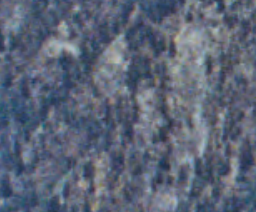

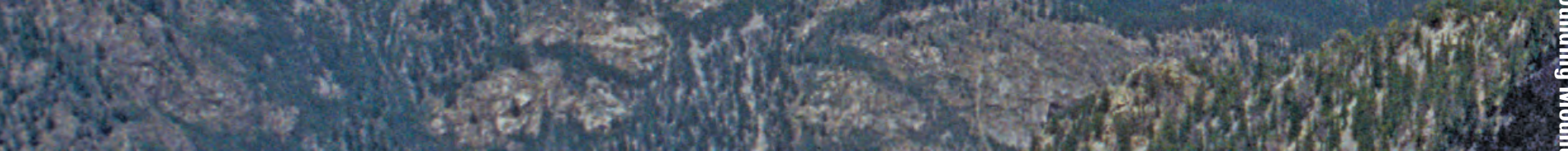

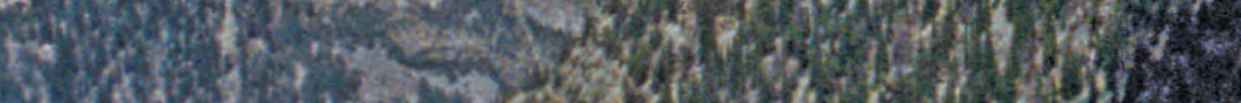

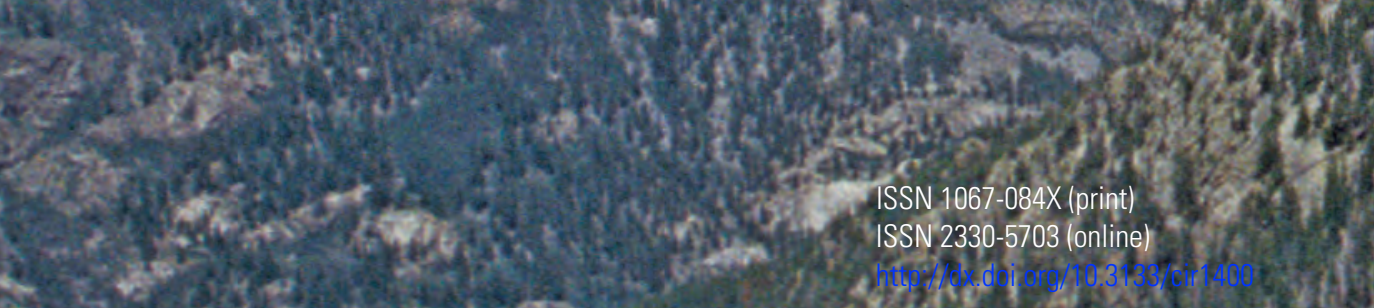

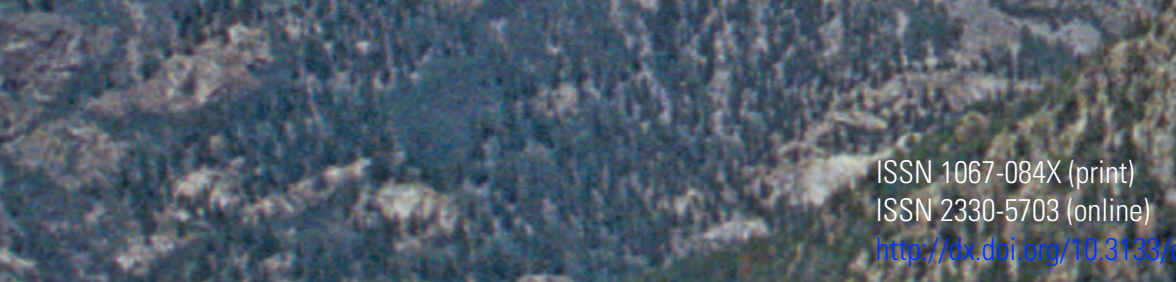
SF * 